\title{
A Review on the Properties of Azadirachta indica, Ocimum tenuiflorum and Cymbopogon citratus
}

\author{
${ }^{1}$ Lakhnarayan Kumar Bhagarathi, ${ }^{2}$ Ms. Ferial Pestano, ${ }^{3}$ Mrs. Zenesia Phillips-Henry, ${ }^{4}$ Ms. Chalasa \\ Cossiah, ${ }^{5} \mathrm{Mr}$. Phillip N. B. DaSilva, ${ }^{6} \mathrm{Mr}$. Dharamdeo Singh \\ 1,2,3,4,5,6 Division of Natural Sciences, University of Guyana, Berbice Campus, Tain, Corentyne, Guyana
}

\begin{abstract}
Herbal and Medicinal plants are terminologies used for plants around the world as they possess significant therapeutic potential. The objective of this study was to assess the properties and biological activities of these plants as well as their phytochemistry. The results of this study were done descriptively and placed into various tables. Analysis showed that Azadirachta indica possessed eighteen (18) therapeutic properties and sixty-five (65) biologically active compounds, Ocimum tenuiflorum possessed twelve (12) therapeutic properties and eighty-two (82) biologically active compounds were noted and Cymbopogon citratus possessed six (6) therapeutic properties and sixty-four (64) biologically active compounds were reported and analyzed. This study revealed that medicinal and herbal plants have great significance and are greatly overlooked. They can be used to resolve a variety of issues worldwide such as: avoiding microbial and insect resistance in species and even be useful in this time of pandemic against the SARS-CoV-2 (COVD-19 Virus). More studies should be done by health authorities, food authorities, agriculture authorities and other organizations with these plants and other medicinal and herbal plants to maximize their benefits.
\end{abstract}

Keywords: Medicinal Plants, Therapeutic, Properties, Phytochemicals, Biological Activity, Drugs.

\section{Introduction}

\section{Medicinal and Herbal Plants}

Human beings, since the dawn of time, have been continually dependant on various species of plants for many reasons, with healthcare, being the biggest of concerns. The National Product and Drug Discovery, 2018 defined medicinal plants as those plants that possesses therapeutic properties, or they exert beneficial pharmacological effects on the body of humans or animals. A herb is a plant or a part of a plant that is utilized for its scent, flavours or therapeutic properties and is labeled to be 'natural'. It can be sold in various forms such as tablets, capsules, extracts, powders, tea and fresh or dried plants for the benefit of improving the state of human health (Medline Plus, 2020). Today, many developed countries are embarking on vigorous research and experimentations which have led to the development of many derived plants products now utilized for many different purposes. Many of these medicinal and herbal plants have been utilized not only as a source of medicine for humans and livestock' alike but also as pesticides to protect crops from pests and diseases.

Medical and herbal plants have been distributed across many habitats and landscapes around the world. In the tropical forests in Eastern and Western Ghats, Chota Nagpur plateau, Aravalis and the Himalayas; seventy percent (70\%) of India medicinal plants are found (Mittermeier \& etal, 2005). Many countries of Europe and Asia such as: Egypt, Greece, China, Arabia; even the North America and Mexico and even countries in South America such as Guyana have recorded the utilization of medical and herbal plants. Seventy to ninety percent (70-90\%) of medicinal and herbal plants can be collected from forests and natural habitats (Principe, 1991).

Impact of Medicinal and Herbal Plants on Medicine 
Eighty percent $(80 \%)$ of people in the world are dependent on traditional medicine and herbs for their survival (FAO, 1996). The Food and Agricultural Organization (FAO), 1996 further stated that domestic animals utilize medicinal plant extracts for their active compounds or products that is essential for their health.

The World Health Organization (WHO), 2004 released statistics that revealed the global trade for plant-based drugs from an estimated US\$ one hundred (100) billion. Traditional medicines from plants accounted for sixty (60) billion of the overall income. According to Export and Import Bank of India, 2003; the trade of herbal teas, drug adjuncts and dietary food was estimated at US\$ five (5) billion in 1997. EXMI also stated that India has approximately one hundred fifty thousand $(150,000)$ practitioners who practice traditional medicines and herbal remedies from plant species and over ten thousand $(10,000)$ licensed pharmacies that manufacture plant products and drugs from plants. Also, EXMI statistics revealed that medicinal herb trade in India is estimated to be US\$ one (1) billion and India exports US\$ two hundred eighty-seven (287) million annually for medical herbs.

\section{General Uses of Medicinal and herbal plants}

There are many species of medicinal plants as well as herbal plants that are utilized by many people around the world. Rural areas are particularly known for the use of local traditional medicine, herbalism played an important role in many rural communities. In 2016, The Yanomami of Brazilian Amazon, being assisted by many scientists and researchers, listed one hundred one (101) plants utilized for traditional medicines (Milliken, 2015; Yanomami et al., 2014). Some of these plants poses many benefits including treating systematic diseases, physical ailments, anti-inflammatory responses, antimicrobial responses, use in cancer treatment, etc.

Herbal and medicinal plants are utilized widely in Guyana, some of these plants are: Chamoli (flower) which is believed to be a cure-all and is utilized in tea or as a compress for many reasons such as: an anxiolytic and sedative for anxiety and relaxation, for wound healing and to reduce inflammation or swelling. Another plant is Echinacea (leaf, stalk, root) which is used to treat and prevent colds, flu, and infections, and for also wound healing. Garlic (cloves, root) is also another plant mainly utilized for lowering cholesterol and blood pressure of humans and it also has antimicrobial effects. Garlic is also known to cause small reductions in total and LDL cholesterol. Another widely used plant is Ginger (root) which is used to ease nausea and motion sickness. Ginger helps in relieve nausea caused by pregnancy or chemotherapy (Freeborn \& Garilli, 2020). Coriander or dhania (Celery) is another plant of great medicinal importance, it is a common ingredient of any kitchen. Celery leaves, seeds and powder of the seeds contribute to a lot of health benefits such as: Prevents the food from spoiling, it is rich in antioxidants, cures urine retention, improves digestion, it regulates your menstrual cycles, and treats acne. Another plant of great significance that we utilize is the Aloe vera, it treats a wide variety of health problems that includes constipation, digestive distress, acne, and poor body immunity (Doctor NDTV, 2019). Traditional Chinese medicine uses many species of plants utilizing their materials and certain techniques. Research provided by Kew Gardens found one hundred four (104) species of medicinal and herbal plants are used for monitoring and managing diabetes in Central America (Giovannini et al., 2016).

\section{General Properties of Medicinal and Herbal Plants and the Issues they can help resolve}

Human beings depend on plants in nature for many different reasons e.g., medicines, shelters, food stuffs, fragrances, clothing, flavours, fertilizers and means of transportation. Medicinal plants dominate the entire world by making the biggest contribution to scientific research and medicine. Herbal treatment and remedies have been an integral part of our world from ancient time to date, as such it played a vital role in history to cure many sicknesses (Fakim, 2006).

Over the years, research have revealed that forty percent (40\%) of plants are used for research prescription drugs and traditional research (Herbal Treatment, 2020). According to a statistical chart provided by Rana \& et al in 2014, it revealed that $1.57 \%$ of plant products come from the bark, $3.47 \%$ of plant products are prepared from the seeds, $4.54 \%$ are produced from the wood, $7.82 \%$ are manufactured from the flowers of species 
ofplants, $13.04 \%$ are processed from fruits and fruiting structures, $17.39 \%$ are products of the plant stems and $39.13 \%$ of products in the world are spanned from the utilization of the plant leaf (Rana \& et al, 2014).

These plants possess many potential properties some of which are: they are used in chemical production, cosmetics, pharmaceuticals and drugs and even as industrial raw materials. In the discovery of new and improved drugs, medicinal plants play the most significant role. Medicinal and herbal plants have demonstrated resilience in coping with many lethal diseases that have plagued and affected us over the years. These plants cope with many cancerous conditions and viral diseases like: Hepatitis and AIDS. The USA Drug Market documented approximately 100 new plant drugs that were present during the period of 1950-1970. Some of these drugs are vincristine, reseinnamine, vinblastine, deseridine and reserpine. During the time frame of 1971-1990, many new plant drugs were introduced to the world, namely: artmisinin, zguggulsterone, ginkgolides, lectinam, E-guggulsterone, teniposide, ectoposide, plaunotol and nabilone. During the period 1991-1995, only $2 \%$ of plant medicines were present, these included: irinotecan, toptecan, paclitaxel and gomishin etc. In 1953, Serpentine that was created from the plant Rauwolfia serpentine root was an excellent way to treat hypertension and lowering blood pressure. In addition, the plant drug vinblastine was used for the treatment of leukemia in children (Harrison, 1998) (Jones, 1998). In Japan, the Indian indigenous tree Nothapodytes nimmoniana (Mappia foetida) is used to cure cervical cancer (Hamburger\& Hostettmann, 1991). In the year 2005 and 2007 respectively, Marinelli and IUCN Species Survival Commission, they reported that worldwide over fifty thousand to eighty thousand $(50,000-80,000)$ species of flowering plants were utilized for medicine and commercial purposes. Furthermore, the Ecology Society of America, 1997 revealed that in the United States of America, out of one hundred fifty (150) most utilized drugs, one hundred twenty (120) were created from natural sources: seventy four percent $(74 \%)$ from medicinal plants and herbs, eighteen percent (18\%) from fungal species, five percent (5\%) from bacterial species and three (3\%) from vertebrates such as: snakes and frogs. Drugs that were derived for anti-cancer purposes e.g., Taxol was isolated from the shade tolerant tree-Pacific Yew and today it saves at least thirty thousand $(30,000)$ lives per year (Daily, 1997). Some drugs that were derived from alkaloid compounds that were extracted from the Rosy Periwinkle trees in Madagascar aid children suffering from leukemia. It was found that in the years 1990-1997, eighty five percent (85\%) of this disease in children had been reduced (Botanic Gardens Conservation International, 1966 \& Daily, 1997).

In recent time, a new compound that was discovered in a plant found in Madagascar. Research showed that this compound can provide antibiotics and weaken the chances of epidemics featuring antibiotic resistant diseases (Wang et al., 2006). Some of these antiviral drugs that were derived from plants e.g., star anise can be used to combat endemic viral diseases (Laurance, 2005). Other concepts of developmental drugs for life threatening situations such as: diarrhea, Human Immunodeficiency Virus (HIV) and diabetes and in other cases, drugs that will protect our crops from pests like slugs have been developed predominantly from plants and other sources e.g., microorganism and amoeba (Barnett, 2006).

\section{The Underutilization of Medicinal and Herbal Plants}

Underutilized medicinal and herbal plants are terms commonly applied to plants or crops whose potential has not fully been realized by human beings (Chiew, 2018). Despite these medicinal and herbal plants dwelling being among us for a great number of years, they are many times overlooked as pests (weeds); especially the herbal plants. Instead of maintaining and conserving these plants to rectify certain growing issues such as: protecting yourselves from insects, protecting our domestic pets from parasites or even protecting our kitchen garden from pests' invasions, human beings are destroying many species of these beneficial plants daily.

According to Critchley, 2019, many herbs like the: Citronella grass which is a strong mosquito repellent is destroyed on the lawn of many people for recreational activities e.g., hosting outdoor parties. It has been reported also that these Citronella grass can aid in the repelling of flies if they are present next to the windows of our home. Lemon grass was another herb that Critchley, 2019 noted that is being destroyed. These lemon grass possess strong insecticidal properties that helps to repel insects and can be used to add flavour to our foods that we prepare in the kitchen. If it is properly maintained in planting pots, it can be a decorative plant in 
our yards while growing on our lawn, because it is considered and overlooked as a wild grass or weed, these plants are removed by chopping with hand tool such as cutlass or even removed by machines or equipment such as: slashers or weed hackers. Other herbal plants that were noted to be destroyed in abundance that have strong insecticidal potentials on insect species such as: aphids, beetles, moths, ticks, fleas, roaches, ants, lice, etc. are: Marigolds, Chrysanthemums, Petunias, Mints, Basils, Lavender, Chives and Rosemary.

Among the eighty-thousand $(80,000)$ of the flowering plant species used medicinally worldwide, many species amongst them are the underutilized and in Africa, the Ziziphus species in the Rhamnaceae family is a good example of such a plant. These plants are grown in abundance and has a high economic value. $Z$. jujuba and $Z$. mauritiana are currently the most important amongst the species, especially in China and India where they are cultivated in large scale and exploited for their medicinal use as well as their edible fruits (Mokgolodi et al., 2011).

In 2009, a collaborative research was conducted by Microbial Biotechnology and Dairy Science Laboratory, Department of Animal Production, and the University of Ilorin. Six (6) plant species that are overlooked and underutilized were used in the experiment and among them was a specie of tulsi, Ocimum gratissimum. The experiment was used to show the crude protein content and Ocimum was among one of the plants that have the highest ether extract, and this means the highest crude protein (Belewu et al., 2009).

\section{The Resistance and Tolerance of Microbes and Insects}

Antimicrobial substances are synthetic drugs that kills or inhibit the growth of microorganisms such as: bacteria, fungi, or protozoans. Disinfectants are used to kill microbes outside of the body of an organism. Since the creation of the first antibiotic, many microorganisms have adapted and developed resistant to antimicrobial agents. Old antimicrobial techniques were developed by poisons or heavy metals which will not completely kill the microbe but allow it to survive, evolve (change) and become resistant to poisons and the heavy metals. Recent plant extracts are use to develop new synthetic drugs such as: essential oils. Many plants can inhibit the growth of microbes and so many plant drugs derived from these oil extracts are synthesized recently (Libre Texts, 2020).

Microorganisms and many species of insects have the tendency to resist synthetic drugs that are already in existence. By further exploring the potential properties of these medicinal and herbal plants, it can help us to create newly improved synthetic drugs for the medical world. By wisely utilizing these extracted phytocompounds from these plants, it will allow these organisms to be more susceptible to these drugs and as such they will not tend to develop a resistance to them very quickly. Insects undergo a series of evolutionary changes overtime in the ecosystem. Many species of insects serve as a vector for certain parasites and microbes that can be detrimental to human health. Some of these diseases includes malaria, chagas disease, bubonic plague, dengue fever and Lyme disease. Some can also be dangerous to animals and even damage food crops e.g., locusts, trees e.g., gypsy moths and homes like termites. Insects cause a lot of economic loss and overtime they develop resistance when insecticides are overused on them. As a result of this genetically altered insect crops are produced and the need for new insecticides for pest management and insect related damage and disease is of great importance (Conte Jr., 1997). The use of many restricted insecticides has been restricted due to high cost, harmful environmental effects, non-biodegradable nature, and increasing insecticidal resistance (Ghosh et al., 2012).

Medicinal and herbal plant extracts and their derivatives have been studied thoroughly by scientists for pest control strategies, assessing the toxicity, lethal, repellent, antifeedant, fumigant, growth regulation, and deterrent effects on oviposition of insects (Isman, 2006). Insects have a chance of developing convectional insecticides which have a single active compound. Botanical (plant) insecticides however contain mixtures of various chemical compounds which can affect behavioural and physiological processes thus the chance of developing resistance is low.

In the year 2013, the Guyana Chronicle published an article stating that "the Azadirachta indica is a very abundant plant that is widely distributed throughout the landscape of Guyana and is rapidly growing in popularity as the year progress since it functions as an herb used for the treatment of a variety of conditions 
that are common to tropical countries". According to Vafaie, 2019; noted the abundance of Azadirachta indica growing among many crop plants such as peppers, tomatoes, cabbage, citrus, melons, eggplant and some tropical fruit, such as soursop and starfruit here in Guyana. Ocimum tenuiflorum are grown in plant pots, in the yard or the gardens and these plants proliferate plentifully and are found almost everywhere in Guyana and are use for traditional remedies by many Guyanese (Dyal, 2019). Cymbopogon citratus are grows very abundant with a wide variety of species found across the landscape of Guyana, however these plants grow in patches and is viewed as a type of invasive weed (Chin, 2019).

In Guyana, the potential of these medicinal plants such as: Azadirachta indica, Ocimum tenuiflorum and Cymbopogon citratus is greatly overlooked by human beings. Many people are not aware of the hidden properties as well as the potential and hidden values possessed by these plant species, thus people tend not to utilize them to gain maximum benefits. Generally, people are aware that Azadirachta indica have insecticidal properties and so they are used to repel insects from grains such as rice, however Azadirachta indica possesses many other hidden properties like anticancer properties, antimicrobial properties and even antiviral and antifungal properties. The major purpose of this study seeks to target and make a major impact on not only locals but also research, pharmaceuticals, and medicine to raise awareness, product development and more utilization of these medical and herbal plants in everyday life to resolve world problems such as: diseases, pests, and control, etc.

\section{Azadirachta indica}

Azadirachta indicia commonly known as 'neem', 'nim', 'limbo', 'medusa', 'nimba' and 'vempu' and is referred to as "The Village Pharmacy" (Ali et al., 2013; Paul et al., 2011; Manogaran et al., 1998). It is a fastgrowing tree that is evergreen, and it has been used to treat many diseases for more than four thousand $(4,000)$ years (Sharma et al., 2011). These trees are characterized by having a bitter taste and new leaves appear in March- April. Some of these trees grow to the height of 15-20 meters and rarely 35-40 meters (Parinitha et al., 2005). The leaves, seeds, fruits, and roots of the neem is a source of more that one hundred forty (140) chemically and structurally complex biological active components such as: meliacin, salanin, nimbin, etc. (Ali \& El-Anany, 2017). The flowers and fruits are produced within the axillary clusters and the drupes that are produced are greenish yellow and entails a sweet pulp enclosing the seeds (Rupani \& Chavez, 2018).

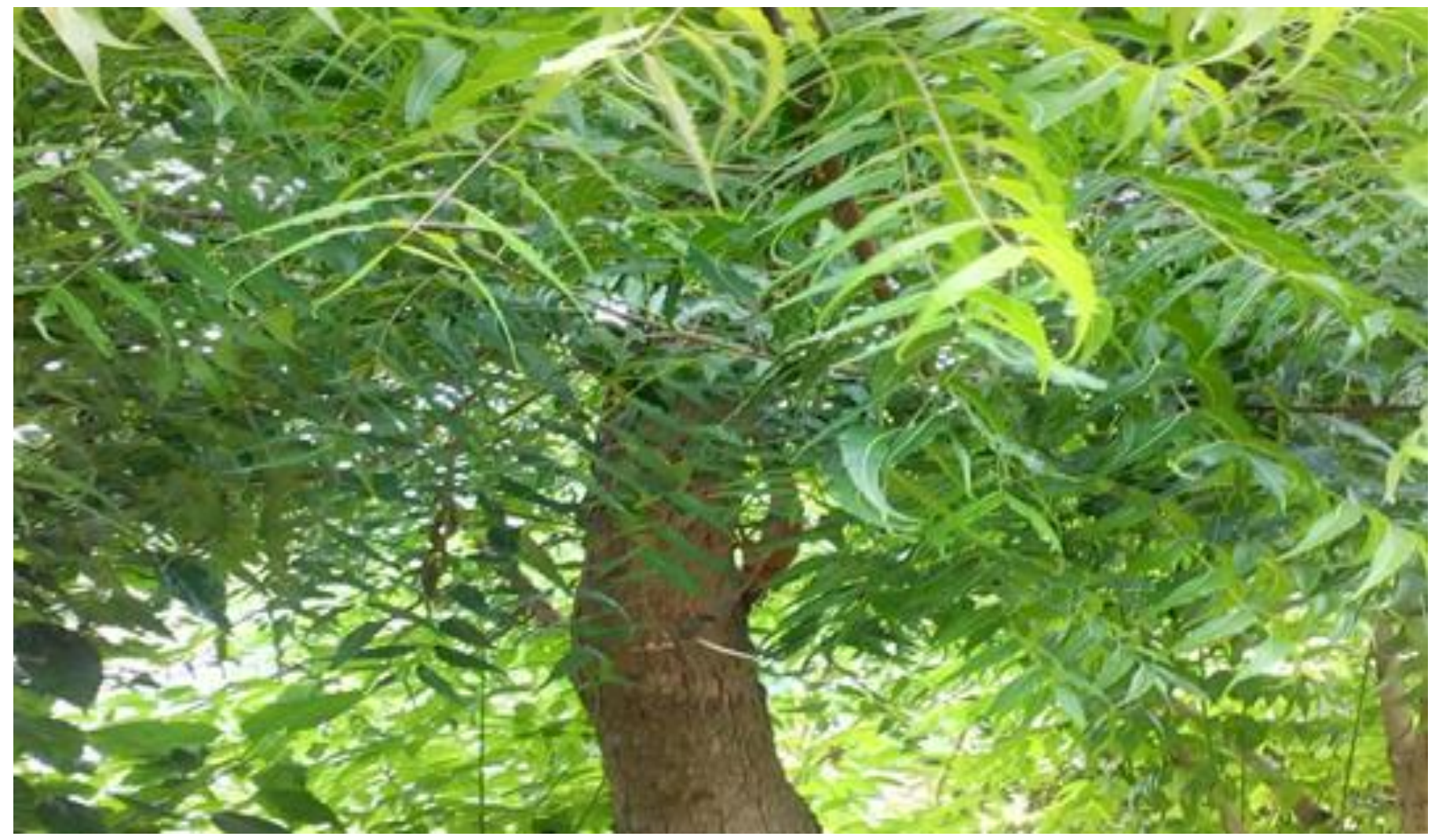

Figure 1: Azadirachta indica (Zero Waste Market Place, 2021). 


\section{Ocimum tenuiflorum}

Ocimum tenuiflorum is also known as Tulsi and the Holy Basil. It is a plant from the genus Ocimum and belonging to the family Labiate and it has great therapeutic potential. There are many other species of Ocimum that are great known importance such as: Ocimum basilicum (Ban Tulsi), Ocimum canum (Dulal Tulsi), etc. (Ocimum sanctum, 1992) (Pandey, 1990). These plants are found in many different parts of the world e.g., Japan, Germany, Tamil Nadu, China, etc. (Trivini \&etal., 2013). Ocimum is characterized as a small herbal plant which is branched with small leaves. This plant grows to a height of one to three (1-3) meters in height. The leaves of this plants have opposite phyllotaxy and the petiole is two to five centimeters $(2-5 \mathrm{~cm})$ long, slender and pubescent. Their colour ranges from green to purple and the leaves are silky of three to four (centimeters $(3-4 \mathrm{~cm})$ long and one to two centimeter $(1-2 \mathrm{~cm})$ broad. Their stems become woody as the plant age. Their roots contain essential oils and is utilized in plant culturing and treatment (Sembuligam et al., 1997).

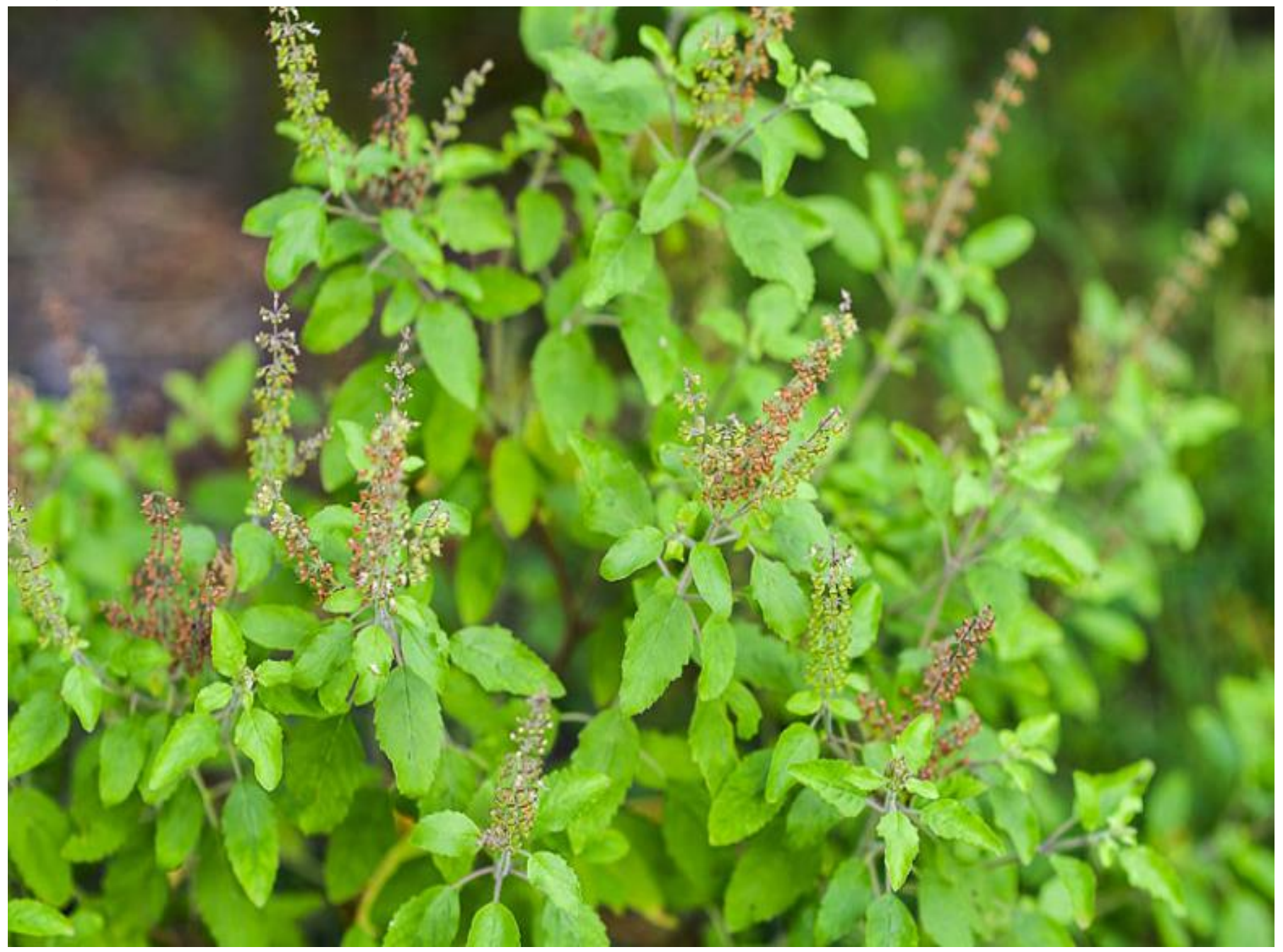

Figure 2: Ocimum tenuiflorum (Gardenia, 2021).

\section{Cymbopogon citratus}

Cymbopogon citratus is commonly called Lemon Grass, is an aromatic perennial tall grass and possess rhizomes and densely tufted fibrous root. This plant has short underground stems with ringed segments, coarse, green slightly leathery leaves in dense clusters (Carlin et al., 1986). Cymbopogon is cultivated in tropical and subtropical regions around the world. This plant grows at an elevation up to nine hundred meters $(900 \mathrm{~m})$. The plant grows best in warm humid climates. Lemon grass serves a multitude of purposes ranging, from food ingredients, to the fields of cosmetics, as a local medicine around the world and possesses many other hidden potentials (Burkill, 1935). Lemon grass usually grows anywhere and is very abundant. It's grass like features make it easily viewed as a weed that spreads and grows wildly. 


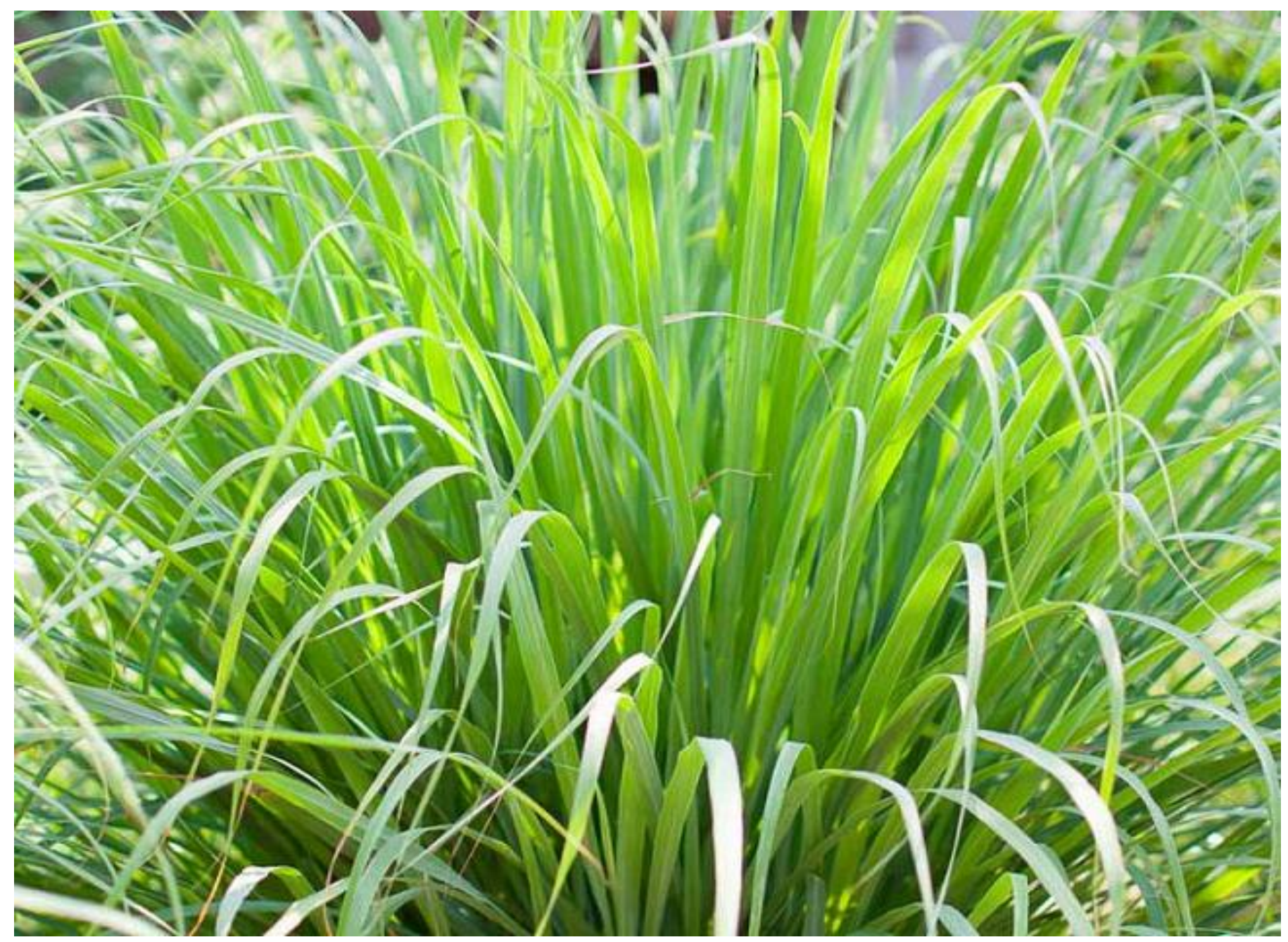

Figure 3: Cymbopogon citratus (Gardenia, 2021).

\section{Cultivation and Preparation of Medicinal and Herbal Plants}

The cultivation and maintenance of medicinal plants is highly dependent on intensive management. Each species may require their own conditions where they are to be cultivated. Rotation of the cultivation of these plants is highly recommended to prevent plant diseases caused by pathogens as well as invasion by certain pests (Dharmananda, 1997).

Many species of medicinal plants and herbal plants are denoted by tough fibrous root systems and require special methods for preparation. The Institute for Traditional Medicine selected various methods for the preparation of herbal medications such as: extraction of alcohol, powdering and decoction in these cases yielding mixture of substances. The method of powdering, involves the drying of plant materials, followed by crushing to yield the powder that is then compressed to tablets. Decoction is the process by which the plant materials are first crushed then boiled to acquire liquid extracts. When extracting alcohol from plants, the plant material is first soaked in distilled spirit or cold wine to form a tincture (Dharmananda, 1997). Traditional poultices are usually prepared by boiling the plant or part of the plant and then wrapping them in cloth, before applying to the affected part of our body (Mount, 2015). When new medicinal plants have been identified, commercial quantities of these drugs are either extracted or synthesized from the plant material and the pure medicinal chemical is yielded (Pezzuto, 1997).

The Scopus Database revealed the trend on how plants are being utilized in scientific research as well as how these other plant products are being used. The categories in the field of Pharmacology, Toxicology and Pharmaceutical own $27.1 \%$ of the total overall of plant products and uses. Many other categories of relative significance include: $23.8 \%$ as Medicines, $16.7 \%$ in the fields of Biochemistry, Genetics and Molecular Biology, $11 \%$ in Agricultural and Biological Sciences, $8.7 \%$ in the fields of Chemistry, $2.5 \%$ in the study of Immunology and Microbiology, $2.1 \%$ for Environmental Science and studies and $1.5 \%$ for Chemical 
Engineering. Many of the other remainder $1 \%$ have been used for other disciplines e.g., Nursing, Multidisciplinary or Engineering (La Cruz-Lovera et al., 2017).

\section{Methodology}

- The method used for this research involved retrieving, assessing and evaluating research papers relevant to the Potential Properties of Azadirachta indica, Ocimum tenuiflorum and Cymbopogon citratus.

- $\quad$ The search terms used in the titles of publications include: potential properties, general properties of medicinal and herbal plants, issues medicinal and herbal plants help to resolve: medicinal plants, herbal plants, neem, tulsi, lemon grass, benefits of medicinal and herbal plants, the underutilization of herbal and medicinal plants, the resistance and tolerance of microbes and insects and cultivation and preparation of medicinal and herbal plants.

- In total 64 articles were used for this review, 24 that focused on Azadirachta indica, 22 that focused on Ocimum tenuiflorum and the remaining 18 focused on Cymbopogon citratus.

- The search for recent scientific papers were restricted to publications between 2000-2020. However, while researching relevant information were utilized from scientific papers between 1935 and 2000 which goes to show how important the study on potential properties of medicinal and herbal plants are since it has been around for as long as eight (8) decades.

- $\quad$ Based on the many scientific articles that were retrieved and utilized from scientific websites, journals, etc.; papers were grouped into various sub-headings according to the relevance and similarity of the information and contents that are present on them e.g., articles that address the underutilization of medicinal and herbal plants is separate from the information that address the resistance and the tolerance of microbes and insects.

- Moreover, the results and discussion section of this scientific research consisted mainly of information from the past 30 years starting from the year 1990 dating to the current year 2020.

\section{Results}

\section{Properties}

Table One (1) showing the Properties of Azadirachta indica.

\begin{tabular}{|c|c|c|}
\hline Author(s) & Properties & Description of Properties \\
\hline $\begin{array}{l}\text { (Ghonmode } e t \\
\text { al., 2013), } \\
\text { (Hussain et al., } \\
\text { 2017), } \\
\text { (Shah et al., } \\
\text { 2017), } \\
\text { (Mafou- } \\
\text { Sonhafouo et } \\
\text { al., 2019). }\end{array}$ & $\begin{array}{c}\text { Antimicrobial } \\
\text { Activities }\end{array}$ & $\begin{array}{l}\text { Antibacterial Activity: The bark and leaf extracts possessed } \\
\text { antibacterial activity on all the bacteria that were tested on. } \\
\text { However, the seed and fruit extracts showed activity at only } \\
\text { higher concentrations. Neem Bark Extract (N.B.E) have been } \\
\text { found to block HSV-1 entry into cells when concentration } \\
\text { ranges from } 50-100 \mu \mathrm{g} / \mathrm{mL} \text {. Neem also displayed great } \\
\text { potential since it is used to dress wounds. The stem and bark of } \\
\text { neem has a great antibacterial potential against the bacteria } \\
\text { Klebsiella serratia and Streptcoccus. The methanolic leaf } \\
\text { extract is very active against Vibrio cholera. The chloroform } \\
\text { extract worked effectively against Eschericha coli, Bacillus } \\
\text { subltilis, Enterococcusfaecalis and Streptococcus faecalis. }\end{array}$ \\
\hline
\end{tabular}




\begin{tabular}{|c|c|c|}
\hline $\begin{array}{c}\text { (Badam et al., } \\
\text { 1999), } \\
\text { (Hirpa, 2017), } \\
\text { (Borkotoky \& } \\
\text { Banerjee, } \\
\text { 2020), } \\
\text { (Lim et al., } \\
\text { 2021). }\end{array}$ & & $\begin{array}{l}\text { Antiviral Activity: The methanolic extract of neem leaves } \\
\text { contained a lot of viral activities against coxsackievirus virus B- } \\
\text { 4. The antiviral activity of neem originated from the presence of } \\
\text { flavonoids, triterpenoids and glycosides present in the leaves of } \\
\text { neem. The leave's inhibitory concentration ( } 8000 \mu \mathrm{g} / \mathrm{mL} \text { ) of the } \\
\text { leaf extract was found to have no toxicity against Vero (African } \\
\text { Green Monkey Kidney) cells. Neem leaf aqueous extract was } \\
\text { very effective against small pox, fowl pox, polio and HIV when } \\
\text { studied using virus inhibition assay. } \\
\text { A. indica evaluation showed positive antiviral evidence specific } \\
\text { to the dangerous acute respiratory syndrome of coronavirus } 2 \\
\text { (SARS-CoV-2). Molecular docking studies have demonstrated } \\
\text { that the neem derived phytocompounds: Nimbolin A, Nimocin, } \\
\text { and Cycloartenols have the potential to bind to envelope (E) and } \\
\text { membrane (M) glycoproteins of the SARS-CoV-2 and act as } \\
\text { inhibitors }\end{array}$ \\
\hline $\begin{array}{l}\text { (Kabeh, 2009), } \\
\text { (Wang et al., } \\
\text { 2010), } \\
\text { (Mahmoud et } \\
\text { al., 2011), } \\
\text { (Hamid et al., } \\
\text { 2019). }\end{array}$ & & $\begin{array}{l}\text { Antifungal Activity: The aqueous, ethanolic and ethyl acetate } \\
\text { extracts from the neem leaf have showed significant activities in } \\
\text { inhibiting the growth of the In Vitro fungi Monilinia fruticola, } \\
\text { Penicillium expansum, Trichothecium roseum, Alternaria spp., } \\
\text { Aspergillus flavus, Aspergillus fumigatus, Aspergillus niger, } \\
\text { Aspergillus terreus, Candida albicans and Microsporum } \\
\text { gypseum. The ethyl acetate extract showed the highest } \\
\text { antifungal activity. Recent research showed the neem in its } \\
\text { powder form when added to acrylic resin denture base materials } \\
\text { reduced the adhesion of } C \text {. albicans thus preventing denture } \\
\text { stomatitis. }\end{array}$ \\
\hline $\begin{array}{l}\text { (Dwivedi et al., } \\
\text { 2016), } \\
\text { (Hariono et al., } \\
\text { 2019). }\end{array}$ & Anti-Dengue Activity & $\begin{array}{l}\text { Dengue viruses is considered a zoonotic disease and is spread to } \\
\text { many people through the bite of an infected Aedes aegypti. This } \\
\text { mosquito specie also spread other diseases e.g., Zika, } \\
\text { chikungunya, and other deadly viruses. Newly developed Anti- } \\
\text { Dengue drugs are used to target NS2B-NS3 protease (NS2B- } \\
\text { NS3 pro) of Dengue Virus (DENV). In silico studies, the } \\
\text { triterpenoids in neem e.g., Nimbin, Deacetylnimbin, } \\
\text { Azadirachtin and Salannin was found to inhibit DENV NS2B- } \\
\text { NS3 proliferation using molecular docking. }\end{array}$ \\
\hline
\end{tabular}




\begin{tabular}{|c|c|c|}
\hline $\begin{array}{c}\text { (Akin- } \\
\text { Osanaiya, } \\
\text { 2013), } \\
\text { (Habluetezl et } \\
\text { al., 2019). }\end{array}$ & Antimalarial Activity & $\begin{array}{l}\text { The antimalarial activity of the neem originated from the leaf, } \\
\text { stem and bark of the plant and it have been evaluated against } \\
\text { Plasmodium berghei in infected albino mice. The extracts from } \\
\text { these plants show great efficiency in reducing the level of } \\
\text { parasitemia in infected mice to about } 51-80 \% \text { and } 56-87 \% \\
\text { respectively. The methanolic extracts from seed kernels of ripe } \\
\text { and unripe fruits from the neem tree was found to inhibit early } \\
\text { erythrocytic schizogony of } P \text {. berghei in infected inbred mice. }\end{array}$ \\
\hline $\begin{array}{l}\text { (Mordue et al., } \\
\text { 1995), } \\
\text { (Mordue et al., } \\
\text { 1995), } \\
\text { (Viera, 2013), } \\
\text { (Paula et al., } \\
\text { 2019). }\end{array}$ & $\begin{array}{l}\text { Antifeedant Activity } \\
\text { (Larvicidal Activity) }\end{array}$ & $\begin{array}{l}\text { When the entomopathogenic fungi Metarhizium anisopilae is } \\
\text { combined with neem oil, it was found that it was capable of } \\
\text { increasing the half-life and virulence of the fungus when being } \\
\text { test against Aedes aegypti larvae under different conditions. The } \\
\text { neem oil also displayed a protective activity towards M. } \\
\text { anisopilae when it was subjected to the damaging effects of } \\
\text { ultraviolet radiation. Studies conducted showed that the } \\
\text { antifeedant and toxicity properties of Azadirachtin with different } \\
\text { less structurally complex biosynthetic precursors against the } \\
\text { larvae of: Sopodoptera littoralis (Boisd), Sopodoptera gregaria } \\
\text { and Oncopeltus fasciatus Dallas (Milkweed Bug) and it revealed } \\
\text { that the toxicity level sever growth and molt disruption. }\end{array}$ \\
\hline $\begin{array}{l}\text { (Chattopadhyay } \\
\text { et al., 2004), } \\
\text { (Ofosori et al., } \\
\text { 2010), } \\
\text { (Bhajoni \& } \\
\text { Meshram, } \\
\text { 2016), } \\
\text { (Neelmani \& } \\
\text { Kumar, 2016). }\end{array}$ & $\begin{array}{c}\text { Anti-ulcerative } \\
\text { Activity }\end{array}$ & $\begin{array}{l}\text { Neem played an integral and important role in the treatment of } \\
\text { pectic ulcers. The aqueous extract from neem leaves was found } \\
\text { to display the Anti-ulcerative activity on Wistar rats when a } \\
\text { dose of } 600 \mathrm{mg} / \mathrm{kg} \text { was applied. Neem have also been evaluated } \\
\text { against pectic ulcers in albino mice. The mechanism for Anti- } \\
\text { ulcerative activity of the neem extract have also been } \\
\text { determined. Nimbidin is responsible for the antiulcer effect } \\
\text { which prevent acetylsalicylic acid, omethacin, serotine-induced } \\
\text { gastric lesions and histamine from the leaf extracts to show anti- } \\
\text { ulcer effect and mucus depletion inhibition and cell } \\
\text { defragmentation as possible mechanisms. }\end{array}$ \\
\hline $\begin{array}{l}\text { (Dholi et al., } \\
\text { 2011), } \\
\text { (Patil et al., } \\
\text { 2013), } \\
\text { (Dubey et al., } \\
\text { 2019). }\end{array}$ & $\begin{array}{c}\text { Hypoglycemic } \\
\text { Activity } \\
\text { (Antidiabetic Activity) }\end{array}$ & $\begin{array}{l}\text { The ethanoic extract from the neem root bark have been noted to } \\
\text { possess antidiabetic activity. When a dose of } 800 \mathrm{mg} / \mathrm{kg} \text { dose of } \\
\text { neem root bark extract (NRE) is utilized in an oral glucose } \\
\text { tolerant test (OGTT) it showed statistically significant results. } \\
\text { At a dose of } 250 \mathrm{mg} / \mathrm{kg} \text { (single dose study), it reduced the } \\
\text { glucose level by } 18 \% \text { in treated diabetic rats versus the control }\end{array}$ \\
\hline
\end{tabular}




\begin{tabular}{|c|c|c|}
\hline & & $\begin{array}{l}\text { group as well as the cholesterol level is reduced by } 15 \% \text {, } \\
\text { triglycerides level is reduced by } 32 \% \text {, urea by } 13 \% \text {, creatinine } \\
\text { by } 23 \% \text { and lipids by } 15 \% \text {. When multiple doses are } \\
\text { administered over a } 15 \text { days period, it also lowered the blood } \\
\text { parameter in the treated group. Azadirachtin in the neem was } \\
\text { found to display protective action against pancreatic } \beta \text {-cells. }\end{array}$ \\
\hline $\begin{array}{c}\text { (Durrani et al., } \\
\text { 2008), } \\
\text { (Shah \& } \\
\text { Mahendra, } \\
\text { 2009). }\end{array}$ & $\begin{array}{c}\text { Immuno-Stimulant } \\
\text { Activity }\end{array}$ & $\begin{array}{l}\text { When an infusion of } 4 \% \text { neem leaves was added to fresh } \\
\text { drinking water, it played the role as a growth promoter and a } \\
\text { growth-stimulant in chickens which contributed to an improved } \\
\text { body weight gain, feed conversion ratio (FCR), gross return, } \\
\text { lower mortality and higher antibody titer against infectious } \\
\text { bursal disease (IBD). The aqueous extract of neem leaf was } \\
\text { found to augment humoral and cell-mediated immunity (specific } \\
\text { immune response) and nonspecific immune responses. }\end{array}$ \\
\hline $\begin{array}{l}\text { (Ahmad et al., } \\
\text { 2016), } \\
\text { (Udem et al., } \\
\text { 2018). }\end{array}$ & Antioxidant Activity & $\begin{array}{l}\text { The significant Antioxidant activity originated from the leaf and } \\
\text { bark. The process whereby free radicals are formed is a regular } \\
\text { body task but the molecules formed are unstable and can cause } \\
\text { damage to other cells. Many disorders such as: cardiovascular } \\
\text { disease, health of eye and muscular degeneration and even } \\
\text { cancer are due to the presence of free radicals present in high } \\
\text { quantity in the human body. The extracts from neem helped to } \\
\text { boost the antioxidant levels and protects the body against } \\
\text { chemically induced carcinogens and liver damage. }\end{array}$ \\
\hline $\begin{array}{l}\text { (Hu et al., } \\
\text { 2016), } \\
\text { (Ahmad } \text { et al., } \\
\text { 2017), } \\
\text { (Sathyamurthy, } \\
\text { 2017), } \\
\text { (Sharma et al., } \\
\text { 2017), } \\
\text { (Moga et al., } \\
\text { 2018), } \\
\text { (Sophia et al., } \\
\text { 2018), } \\
\text { (Ahmad } \text { et al., } \\
\text { 2019). }\end{array}$ & Anticancer Activity & $\begin{array}{l}\text { The aqueous and ethanolic extract of the neem leaves have been } \\
\text { tested for its anticancer activity against a number of cell lines } \\
\text { such as: breast, lung and cervical. The tests were done in both in } \\
\text { vitro and in vivo to determine the anticancer effects of neem. } \\
\text { Neem have been noted to show some level of toxicity and side } \\
\text { effects at higher doses, so neem was advisable to use as a } \\
\text { complimentary medicine under the supervision of qualified } \\
\text { practitioners and physicians. Neem is used as a combination } \\
\text { regimen with cisplatin and other chemotherapeutic agents to } \\
\text { improve the efficiency of cancer therapies by decreasing the } \\
\text { chemotherapeutic doses and toxicity of chemotherapeutic drugs. } \\
\text { Nimbolide in neem is noted to promote apoptosis by the } \\
\text { modulation of the phosphoinositide-3-kinase (PI3K) or protein } \\
\text { kinase B (Akt) or glycogen synthase kinase } 3 \text { (GSK-3ß) }\end{array}$ \\
\hline
\end{tabular}




\begin{tabular}{|c|c|c|}
\hline & & $\begin{array}{l}\text { signaling the pathway in oral cancer. The seed oil in neem is } \\
\text { noted to induce apoptosis in MCF- } 7 \text { and MDA MB- } 231 \text { human } \\
\text { breast cancer cells. }\end{array}$ \\
\hline $\begin{array}{c}\text { (Sinha et al., } \\
\text { 1984), } \\
\text { (Armstrong et } \\
\text { al., 2014). }\end{array}$ & Antifertility Activity & $\begin{array}{l}\text { The neem seed oil was found to possess strong spermicidal } \\
\text { properties and inhibit spermatogenesis. Neem was found to } \\
\text { reduce sperm motility and count and cessation of fertility. Neem } \\
\text { also has Anti-implantation and Abortifacient properties. The } \\
\text { spermatozoa of human beings and Rhesus monkeys died within } \\
\text { thirty (30) minutes of contact with neem seed oil using an intra } \\
\text { vaginal dose of } 1 \mathrm{~mL} \text {. }\end{array}$ \\
\hline $\begin{array}{l}\text { (Osunwoke } e t \\
\text { al., 2013), } \\
\text { (Singh et al., } \\
\text { 2014), } \\
\text { (Chundran et } \\
\text { al., 2015). }\end{array}$ & Wound Healing Effect & $\begin{array}{l}\text { Neem oil was scientifically proven to be very beneficial in the } \\
\text { treatment of chronic, nonhealing wounds. After eight (8) weeks } \\
\text { of treatment, } 50 \% \text { wound healing is observed in } 44 \% \text { of the } \\
\text { patients. The aqueous extract from neem exhibited wound- } \\
\text { healing activities by reducing the wound diameter. The extract } \\
\text { acted biochemically through inflammatory and } \\
\text { neovascularization. }\end{array}$ \\
\hline $\begin{array}{l}\text { (Kale et al., } \\
\text { 2003), } \\
\text { (Baligar } \text { et al., } \\
\text { 2014). }\end{array}$ & $\begin{array}{c}\text { Hepatoprotective } \\
\text { Effect }\end{array}$ & $\begin{array}{l}\text { Carbon tetrachloride }\left(\mathrm{CCL}_{4}\right) \text { is used to induced hepatotoxicity in } \\
\text { various animal models and the disease control group showed a } \\
\text { decrease level in the total protein level while the } \\
\text { aminotransferase (aspartate aminotransferase [AAT]) and } \\
\text { alanine aminotransferase (ATL) and alkaline phosphatase levels. } \\
\text { When treated with Azadirachtin-A, it improves the range of the } \\
\text { proteins and enzymes. Pre-treatment with Azadirachtin-A can } \\
\text { reduce hepatocellular necrosis. Aqueous leaf extract of neem } \\
\text { reduces the hepatotoxic damage caused by antitubercular drugs }\end{array}$ \\
\hline $\begin{array}{l}\text { (Monein, } \\
\text { 2014), } \\
\text { (Monein } \text { et al., } \\
\text { 2014), } \\
\text { (Kandhare et } \\
\text { al., 2014). }\end{array}$ & Neuroprotective Effect & $\begin{array}{l}\text { This effect has been observed using animal models. The result } \\
\text { of the peripheral neuropathy (induced by partial sciatic nerve } \\
\text { ligation) animal model reveals a significant decrease in } \\
\text { allodynia, hyperalgesia, motor coordination and motor nerve } \\
\text { conduction velocity which chronic treatment with this extract } \\
\text { attenuated behavioral changes. The neem extract reduced the } \\
\text { enhance effects of oxidative and nitrostative stress, } \\
\text { inflammatory mediators and mRNA expression of Bax and } \\
\text { iNOS, in animal studies. Cisplatin is a neurotoxic agent used in } \\
\text { animal model and it increases the level of lipid peroxidation and } \\
\text { nitric oxide and decrease the glutathione level. With cisplatin- }\end{array}$ \\
\hline
\end{tabular}




\begin{tabular}{|c|c|c|}
\hline & & $\begin{array}{l}\text { induced neurotoxicity, it promotes antioxidant, anti- } \\
\text { inflammatory and free-radical scavenging activities. }\end{array}$ \\
\hline $\begin{array}{l}\text { (Peer et al., } \\
\text { 2008). }\end{array}$ & $\begin{array}{c}\text { Cardioprotective } \\
\text { Effect }\end{array}$ & $\begin{array}{l}\text { A dose of } 200-1000 \mathrm{mg} / \mathrm{kg} \text { helped to restore most of the } \\
\text { hemodynamic, biochemical and histopathological parameters. } \\
\text { Neem showed more cardioprotective effects as compared to } \\
\text { Vitamin E. }\end{array}$ \\
\hline (Thas, 2008). & Pesticide Activity & $\begin{array}{l}\text { Neem oil was utilized as one of the cheapest pesticides in crop } \\
\text { protection. The neem oil formulations have shown great efficacy } \\
\text { against the insects Sitophilus oryzae (rice weevil) and Tribolium } \\
\text { castaneum adults (red flour beetle). }\end{array}$ \\
\hline (Thas, 2008). & Dermatological Effect & $\begin{array}{l}\text { Neem was found to be very effective against chronic skin } \\
\text { conditions. The neem oil showed great responses against acne, } \\
\text { psoriasis, eczema, ringworm and warts. }\end{array}$ \\
\hline $\begin{array}{l}\text { (Francine et al., } \\
\text { 2015). }\end{array}$ & $\begin{array}{l}\text { Anti-inflammatory, } \\
\text { Antipyretic and } \\
\text { Analgesic Activities }\end{array}$ & $\begin{array}{l}\text { The stem bark chloroform extracts from the neem plant showed } \\
\text { efficiency against carrageenan e.g., paw edema in rats and ear } \\
\text { inflammation in mouse. The extracts that originated from the } \\
\text { bark were utilized to treat stomatitis in children. The neem oil } \\
\text { possessed antipyretic activity and the extracts of the leaves } \\
\text { showed the antipyretic effects when doses is injected in male } \\
\text { rabbits. }\end{array}$ \\
\hline $\begin{array}{l}\text { (Pai et al., } \\
\text { 2004), } \\
\text { (Elavarasu et } \\
\text { al., 2012). }\end{array}$ & $\begin{array}{c}\text { Dentistry } \\
\text { (Dental Activities) }\end{array}$ & $\begin{array}{l}\text { Anti-Plaque Activity: The aqueous extract from the neem stick } \\
\text { and gallotannin-enriched extract from Melaphis chinensis } \\
\text { inhibited insoluble glucan synthesis and resulted in bacterial } \\
\text { aggregation. The results showed that the bacteria Streptococci, } \\
\text { colonized the surface of the tooth. Neem oil promoted a lot of } \\
\text { antibacterial activity, it was suggested to help treat dental } \\
\text { plaques. Mucoadhesive dental gel that contain Azadirachta } \\
\text { indica was found to be very beneficial to reduce the teeth plaque } \\
\text { index and salivary bacterial count }\end{array}$ \\
\hline $\begin{array}{l}\text { (Almas, 1999), } \\
\text { (Siswomihardjo } \\
\text { et al., 2007), } \\
\text { (Bohora } \text { et al., } \\
\text { 2010), } \\
\text { (Nayak et al., } \\
\text { 2011), }\end{array}$ & & $\begin{array}{l}\text { Antibacterial Activity: Neem is a natural Antibacterial agent. It } \\
\text { had been reported to work actively against Streptococcus } \\
\text { mutans and Streptococcus faecalis. The ethanolic contents } \\
\text { extracted from the leaves, sticks and bark of the neem plants } \\
\text { exhibited antibacterial activities. The dried chewing sticks of } \\
\text { neem showed the maximum antibacterial activity against } S \text {. } \\
\text { mutans when compared to other dental caries-causing organisms }\end{array}$ \\
\hline
\end{tabular}




\begin{tabular}{|c|c|}
\hline $\begin{array}{l}\text { (Chava et al., } \\
\text { 2012). }\end{array}$ & $\begin{array}{l}\text { such as: Streptococcus mitis, Streptococcus sanguis and } \\
\text { Streptococcus salavarius. }\end{array}$ \\
\hline $\begin{array}{c}\text { (Polaquini et } \\
\text { al., 2006), } \\
\text { (Dhanya \& } \\
\text { Sidhu, 2013). }\end{array}$ & $\begin{array}{l}\text { Anti-Candidial Activity: The aqueous and ethanolic extract from } \\
\text { the neem leaf showed Anti-candidial effect against Candidia } \\
\text { albicans. The extract showed significant effects on adhesion, } \\
\text { surface cell hydrophobicity and biofilm formation on } C \text {. } \\
\text { albicans colonization. The neem was reported to have a } \\
\text { potential anti-adhesive effect on the sample that was studied In } \\
\text { Vitro. }\end{array}$ \\
\hline $\begin{array}{l}\text { (Bhuiyan et al., } \\
\text { 1997), } \\
\text { (Patil et al., } \\
\text { 2010), } \\
\text { (Packia et al., } \\
\text { 2012). }\end{array}$ & $\begin{array}{l}\text { Anti-Cariogenic Activity: The chloroform extract of neem } \\
\text { inhibited Streptococcus mutans and Streptococcus salivarius, } \\
\text { thus provided aid in treating dental caries. Herbal dental cream } \\
\text { (toothpaste) carrying neem and fluoride showed anonymous } \\
\text { antimicrobial activities against } S \text {. mutans. The toothpaste } \\
\text { containing the neem and fluoridated toothpaste was very } \\
\text { effective against caries-producing bacteria. The acetone extract } \\
\text { from the bark of the neem plant proved to have bactericidal } \\
\text { effects against Streptococcus sobrinus hence indicating that } \\
\text { neem exhibited anti-cariogenic activities. }\end{array}$ \\
\hline $\begin{array}{c}\text { (Bohora et al., } \\
\text { 2010). }\end{array}$ & $\begin{array}{l}\text { Root Canal Irrigant: For many years, sodium hydrochlorite have } \\
\text { been used as a root canal irrigant. However, it causes weakening } \\
\text { of the tooth structure by decreasing the hardness and structural } \\
\text { integrity of dentin present in the teeth. The aqueous and } \\
\text { ethanolic extract from the neem leaf is used to inhibit } \\
\text { Streptococcus mutans and Enterococcus faecalis which cause } \\
\text { root canal failure in endodontic procedures. The antioxidant and } \\
\text { antimicrobial effect made it a perfect potential agent for root } \\
\text { canal irrigation and an alternative substitute for sodium } \\
\text { hydrochlorite. }\end{array}$ \\
\hline
\end{tabular}

Table Two (2) showing the Properties of Ocimum tenuiflorum.

\begin{tabular}{|l|l|l|}
\hline Author(s) & Properties & Description of Properties \\
\hline
\end{tabular}




\begin{tabular}{|c|c|c|}
\hline $\begin{array}{l}\text { (Partibha } \text { et al., } \\
\text { 2005). }\end{array}$ & Antitissue Activity & $\begin{array}{l}\text { The fresh fruit and leaf extract is commonly used in the } \\
\text { treatment of cough as: demulcent, mild upper respiratory } \\
\text { tract infection, general stress syndrome, worm } \\
\text { infestations. Traditionally, the tulsi is used singularly or } \\
\text { with a combination of other herbs to treat coughs. The } \\
\text { tulsi brought about the tissue effect by the central action } \\
\text { mediated by both opioid system and GABA-ergic } \\
\text { system. The Ursolic acid compound present in the leaf } \\
\text { promotes Antitissue activity. }\end{array}$ \\
\hline $\begin{array}{l}\text { (Mandal et al., } \\
\text { 1993), } \\
\text { (Kochhar et al., } \\
\text { 2009). }\end{array}$ & $\begin{array}{c}\text { Hypoglycemic } \\
\text { Activity } \\
\text { (Antidiabetic Activity) }\end{array}$ & $\begin{array}{l}\text { The leaves of the tulsi have been shown to promote } \\
\text { hypoglycemic effects in various experimental animals. A } \\
\text { study conducted on rat suggest that various constituients } \\
\text { from the lead extract of the plant promotes stimulatory } \\
\text { effects on physiological pathways of insulin secretion. }\end{array}$ \\
\hline $\begin{array}{l}\text { (Nakamura et al., } \\
\text { 2004). }\end{array}$ & Anticancer Agent & $\begin{array}{l}\text { Surgery, radiotherapy and chemotherapy established } \\
\text { treatment modalities for different types of cancers are } \\
\text { costly, mutilating and have serious side effects and } \\
\text { association with residual morbidity and frequent relapses. } \\
\text { The ethanolic extract from tulsi mediated a great } \\
\text { reduction in tumor cell size and increases the lifespan of } \\
\text { mice suffering from Sarcoma-180 solid tumors. The } \\
\text { Urosolic acid and Oleanolic Acid possessed anti-cancer } \\
\text { responses. }\end{array}$ \\
\hline $\begin{array}{c}\text { (Chattopadhyay, } \\
\text { 1993). }\end{array}$ & $\begin{array}{l}\text { Anti-Hyperlipidemic } \\
\text { Activity }\end{array}$ & $\begin{array}{l}\text { Tulsi fixed oil contains five (5) kinds of fatty acids where } \\
\alpha \text {-linolenic acid is a major fatty acid. The oil depresses } \\
\text { high serum levels of total cholesterol, triglycerides, LDL- } \\
\mathrm{C} \text { and AI whereas no significant effect of HDL-C was } \\
\text { observed. The fixed-oil of tulsi suppressed the high-level } \\
\text { cholesterol and triglyceride with no effect on lipids in } \\
\text { feces. The fixed-oil normalized the high serum levels of } \\
\text { LDH and CK-BM but no significant effect on high serum } \\
\text { levels of ALT, AST and ALP was obtained. The anti- } \\
\text { hyperlipidemic action of neem oil mainly resulted from } \\
\text { the suppression of liver lipid synthesis. Linolenic acid } \\
\text { and linoleic acid from tulsi oil was responsible for lipid- } \\
\text { lowering against hyperlipidemia. }\end{array}$ \\
\hline
\end{tabular}




\begin{tabular}{|c|c|c|}
\hline $\begin{array}{c}\text { (Chopra et al., } \\
\text { (1956), } \\
\text { (Prakash \& } \\
\text { Gupta, 2005). }\end{array}$ & Antifertility Agent & $\begin{array}{l}\text { The Urosolic acid that was present in the tulsi leaf } \\
\text { promoted antifertility effect. This effect came due to the } \\
\text { anti-estrogenic activity which affect spermatogenesis in } \\
\text { males by retarding Sertoli cell activities and inhibited the } \\
\text { implantation of ovum in the females. It is used as an } \\
\text { antifertility agent because it is devoid of side effects. The } \\
\text { leaf extract of tulsi possessed anti-implantation activities } \\
\text { in experimental albino rats. The Urosolic acid in tulsi was } \\
\text { responsible for anti-sterility property. The tulsi leaf also } \\
\text { have antiandrogenic property. The Benzene extract from } \\
\text { the tulsi decreased the total sperm count and sperm } \\
\text { motility in albino rats. }\end{array}$ \\
\hline $\begin{array}{c}\text { (Upadhyay et al., } \\
\text { 1992), } \\
\text { (Rehman et al., } \\
\text { 1999), } \\
\text { (Physiotherapy } \\
\text { Research, 2009). }\end{array}$ & $\begin{array}{c}\text { Immunomodulatory } \\
\text { Agent }\end{array}$ & $\begin{array}{l}\text { Tulsi is used to strengthen the immune responses by } \\
\text { enhancing the cellular and humoral immunity. It showed } \\
\text { great anti-inflammatory action towards aspirin with no } \\
\text { side effects. It helped in the reduction of inflammation } \\
\text { and pain that leads to chronic arthritis. Previous studies } \\
\text { conducted on Freund's adjuvant induced arthritis, } \\
\text { formaldehyde induced arthritis and turpentine-oil induced } \\
\text { joint edema in rats showed significant responses. Anti- } \\
\text { inflammatory activities against carrageenan were also } \\
\text { noted when different mediator-induced paw edema is } \\
\text { applied to rats. Tulsi is very useful since it blocked the } \\
\text { cyclo-oxygenase and lipoxygenase of arachidonic acid } \\
\text { metabolism. }\end{array}$ \\
\hline $\begin{array}{c}\text { (Bhargava \& } \\
\text { Singh, 1981), } \\
\text { (Sen et al., } \\
\text { 1992). }\end{array}$ & $\begin{array}{c}\text { Stress Releasing } \\
\text { Agent }\end{array}$ & $\begin{array}{l}\text { Tulsi leaves are considered to be adaptogens or anti- } \\
\text { stress agent. Studies revealed that the leaves offer } \\
\text { significant protection against stress. Utilizing tulsi twice } \\
\text { a day worked as a powerful calming herb. Studies } \\
\text { revealed that the extracts of tulsi leaves prevented } \\
\text { changes in the plasma levels of the stress hormone } \\
\text { corticosterone induced by both acute and chronic noise } \\
\text { sounds (physical or physiological stress). Stress is } \\
\text { involved in pathogenesis of a variety of diseases, } \\
\text { especially psychiatric disorders such as: depression and } \\
\text { anxiety, immune suppression, peptic ulcers, hypertension } \\
\text { and ulcerative colitis. Tulsi possessed anti-hypoxic effect }\end{array}$ \\
\hline
\end{tabular}




\begin{tabular}{|c|c|c|}
\hline & & and it increased the chance of survival of anoxic stress. \\
\hline $\begin{array}{l}\text { (Singh \& } \\
\text { Majumdar, } \\
\text { 1995). }\end{array}$ & Analgesic Activity & $\begin{array}{l}\text { In certain pain models (tail flick, tail clip and tail } \\
\text { immersion methods), tulsi was found to be a devoid of } \\
\text { analgesic activity. It was found to be effective against } \\
\text { acetic induced writhing methods in mice at a dosage in a } \\
\text { dependent manner. The result of the writhing inhibiting } \\
\text { activity of the oil suggested that its peripherally mediated } \\
\text { due to the combined inhibitory effects of prostaglandins, } \\
\text { histamine and acetylcholine. }\end{array}$ \\
\hline $\begin{array}{c}\text { (Pratheeba } \text { et al., } \\
\text { 2015). }\end{array}$ & $\begin{array}{c}\text { Larvicidal, Pupicidal } \\
\text { and Adulticidal } \\
\text { Potential }\end{array}$ & $\begin{array}{l}\text { Larvicidal, pupicidal and adulticidal activities originated } \\
\text { from the acetone, hexane and chloroform extracts from } \\
\text { the leaf of the tulsi plant. The results revealed that the } \\
\text { chloroform was the best controlling agent against the } \\
\text { filariasis mosquito Qulex quinquefasciatus among the } \\
\text { other extracts present. Pupicidal and larvicidal mortality } \\
\text { have been recorded when the same extract is exposed for } \\
\text { twenty-four (24) hours at a dosage of } 2.6916 \mathrm{mg} / \mathrm{ml} \text { and } \\
2.8916 \mathrm{mg} / \mathrm{ml} \text {. }\end{array}$ \\
\hline $\begin{array}{l}\text { (Orafidiya et al., } \\
\text { 2005), } \\
\text { (Eyo et al., } \\
\text { 2008). }\end{array}$ & $\begin{array}{c}\text { Wound Healing } \\
\text { Activity }\end{array}$ & $\begin{array}{l}\text { Wound models in rats were used to investigate the wound } \\
\text { healing effects of tulsi. An increase in the vascular } \\
\text { permeability is a major factor that contributed to the } \\
\text { wound healing potential possessed by tulsi. }\end{array}$ \\
\hline $\begin{array}{l}\text { (Tanko et al., } \\
\text { 2008). }\end{array}$ & $\begin{array}{c}\text { Anti-inflammatory } \\
\text { Activity }\end{array}$ & $\begin{array}{l}\text { The inhibitory effect of the chemical constituients of tulsi } \\
\text { oil extract was used for Anti-inflammatory and Analgesic } \\
\text { drugs. The two enzymes lipoxygenase L-1 and } \\
\text { cyclooxygenase function of prostaglandin H synthase } \\
\text { that are involved in the production of mediators of } \\
\text { inhibition was inhibited. }\end{array}$ \\
\hline $\begin{array}{l}\text { (Sadgir et al. } \\
\text { 2010). }\end{array}$ & Antimicrobial Activity & $\begin{array}{l}\text { Antibacterial Activity: Tulsi promoted antibacterial } \\
\text { action against microorganisms that have the tendency to } \\
\text { develop resistance to antibiotics. It was very effective } \\
\text { against microbes such as: Klebisella spp. that causes } \\
\text { pneumonia and urinary tract infection, Escherichia coli, } \\
\text { Salmonella typhi, Pseudomonas pyocyaneus, Vibrio } \\
\text { cholerae, Shigella dysenteriae and Proteus vulgaris }\end{array}$ \\
\hline
\end{tabular}




\begin{tabular}{|c|c|}
\hline & within specified contact time. \\
\hline $\begin{array}{c}\text { (Prabuseenivasan } \\
\text { et al., 2006), } \\
\text { (Silva et al., } \\
\text { 2010), } \\
\text { (Orji et al., } \\
\text { 2015). }\end{array}$ & $\begin{array}{l}\text { Antifungal Activity: The essential oil extract that } \\
\text { originated from the arial parts of the tulsi plants have } \\
\text { been found to contain antifungal activities. The results } \\
\text { showed that the essential oil extract worked significantly } \\
\text { against all tested phytopathogens including: } \\
\text { Botryospaeria rhodina, Rhizoctonia spp. and two stains } \\
\text { of Alternaria spp. Ethanolic, hot water and cold-water } \\
\text { extract of tulsi was tested against Colletotrichum spp. } \\
\text { was isolated from spoil tomatoes. Antifungal activities } \\
\text { were also noted against Micosporum canis, Micosporum } \\
\text { gypseum, Trichophyton rubrum and Trichophyton } \\
\text { mentagrophytes and it was found that eugenol is very } \\
\text { effective against these dermatophytes. }\end{array}$ \\
\hline $\begin{array}{l}\text { (Chiang et al., } \\
\text { 2005), } \\
\text { (Shree et al., } \\
\text { 2020). }\end{array}$ & $\begin{array}{l}\text { Antiviral Activity: Tulsi have also been used since it is a } \\
\text { strong antiviral agent against DNA virus (Herpes Virus- } \\
\text { HSV, Adenovirus-ADV and Hepatitis-B virus) and RNA } \\
\text { viruses. It is also reported to have antiviral activity } \\
\text { against Bovine herpes virus-1. The phytochemicals: } \\
\text { eugenol, carvacol, methyl eugenol, caryophyllene are } \\
\text { responsible for these antiviral activities. } \\
\text { Three (3) compounds of the Tulsi, mainly: Vicenin, } \\
\text { Isorientin 4'-O-glucoside 2"-O-p-hydroxybenzoate and } \\
\text { Ursolic Acid showed significant binding affinity to the } \\
\text { SARS-CoV-2. }\end{array}$ \\
\hline
\end{tabular}

Table Three (3) showing the Properties of Cymbopogon citratus.

\begin{tabular}{|c|c|l|}
\hline Author(s) & Properties & \multicolumn{1}{|c|}{ Description of Properties } \\
\hline $\begin{array}{c}\text { (Lee } \text { et al., 2008), } \\
\text { (Figueirinha } \text { et al., }\end{array}$ & Anti-inflammatory \\
2010), & $\begin{array}{l}\text { Sesponses } \\
\text { isolates are the major components of lemon grass } \\
\text { exhibiting anti-inflammatory activity. The devoid of lipid } \\
\text { and essential oil and polyphenol fractions (phenolic acid, } \\
\text { (Tiwari } \text { et al., 2010), } \\
\text { (Francisco } \text { et al., } \\
\text { 2011). }\end{array}$ & $\begin{array}{l}\text { flavonoids and tannins) was also investigated for anti- } \\
\text { inflammatory responses. The aqueous lemon grass extract } \\
\text { is noted to inhibit the secretion of Nitric Oxide (NO), }\end{array}$ \\
\hline
\end{tabular}




\begin{tabular}{|c|c|c|}
\hline & & $\begin{array}{l}\text { Prostaglandin E2 (PGE2) and expression of Inducible } \\
\text { Nitric Oxide Synthase (iNOS) but not Cyclo-oxygenase } \\
\text { (COX-2) in Lipopolysaccharides (LPS) in RAW } 264.7 \\
\text { macrophage cell lines and skin-derived dendritic cell line. } \\
\text { The polyphenolic extracts revealed a reduced secretion of } \\
\text { Nitric Oxide (NO) and expression of iNOS and LPS } \\
\text { stimulated skin-derived dendritic and RAW } 264.7 \text { cell } \\
\text { lines. However, the flavonoid and tannins showed better } \\
\text { anti-inflammatory potential because of the luteolin } \\
\text { glycosides. The phenolic acid showed satisfactory } \\
\text { inhibition of PGE2 production in LPS induced RAW } 264.7 \\
\text { macrophage. None of the phenolic compounds was found } \\
\text { to inhibit the COX-2 expression. Ethanolic extract from } \\
\text { lemon grass was found to be effective against infections } \\
\text { caused by LPS induced by murine alveolar macrophages. } \\
\text { This mechanism of action was done by the inhibition of the } \\
\text { secretion of NO and pro-inflammatory cytokine tumor } \\
\text { necrosis factor TNF- } \alpha \text {. }\end{array}$ \\
\hline $\begin{array}{l}\text { (Cheel } \text { et al., 2005), } \\
\text { (Figueirinha } \text { et al., } \\
\text { 2008), } \\
\text { (Tiwari et al., 2010), } \\
\text { (Mirghani et al., } \\
\text { 2012). }\end{array}$ & Antioxidant Activity & $\begin{array}{l}\text { Antioxidant potentials of lemon grass was well } \\
\text { documented since they have the ability to reduce Reactive } \\
\text { Oxygen Species (ROS's). Lemon grass showed its } \\
\text { antioxidant property by scavenging superoxide anions and } \\
\text { inhibiting lipoperoxidation and decolorization of 2, 2- } \\
\text { dipenthyl-1-picrylhydrazyl (DPPH). Flavonoid and tannin } \\
\text { extract was found to be the most active anti-oxidative } \\
\text { agent. Aqueous ethanol extract demonstrated antioxidant } \\
\text { activity by decreasing the reactive oxygen species } \\
\text { production and lipid peroxidation and also increased the } \\
\text { superoxide dismutase activity and glutathione formation. } \\
\text { Both the leaves and stalk extract possessed antioxidant } \\
\text { activity because of the radical scavenging abilities against } \\
\text { DPPH. }\end{array}$ \\
\hline (Grace et al., 1984). & Antibacterial Potential & $\begin{array}{l}\text { The volatile portion of lemon grass oil has been } \\
\text { investigated and the } \alpha \text {-citral (geranial) and } \beta \text {-citral (neral) } \\
\text { are the major components. The antibacterial ability of } \\
\text { lemon grass was noted when it inhibited the growth of both } \\
\text { Gram-positive and Gram-negative bacteria specie. }\end{array}$ \\
\hline
\end{tabular}




\begin{tabular}{|c|c|c|}
\hline $\begin{array}{c}\text { (Adejuwon \& Esther, } \\
\text { 2007), } \\
\text { (Do Rego et al., } \\
\text { 2007), } \\
\text { (Celso et al., 2011). }\end{array}$ & $\begin{array}{l}\text { Anti-obesity and } \\
\text { Antihypertensive } \\
\text { Activity }\end{array}$ & $\begin{array}{l}\text { Lemon grass extract is an excellent source of } \\
\text { hypolipidemic and hypoglycemic substances which aids in } \\
\text { lowering hypertension and obesity. When lemon grass } \\
\text { aqueous extracts were fed to rats at } 500 \mathrm{mg} / \mathrm{kg} / \text { day, it led } \\
\text { to a significant reduction in hypoglycemic index despite it } \\
\text { was subjected to counter-regulatory factors e.g., } \\
\text { catecholamine, cortisol and glucagon. The hypolipidemic } \\
\text { effect was recorded when there was a reduction in low } \\
\text { density lipid levels in the blood. The tea of lemon grass } \\
\text { increased insulin synthesis and secretion } \\
\text { (hyperinsulinemia) or increased peripheral glucose } \\
\text { utilization. Lemon grass extracts were effective in reducing } \\
\text { cholesterol levels in the blood. This is due to the presence } \\
\text { of an endogenous ligand of central-type benzodiazepine } \\
\text { receptors known as endozepine octadecaneuropeptide } \\
\text { (ODN) which is a major inhibitor of food intake in small } \\
\text { animals. }\end{array}$ \\
\hline $\begin{array}{c}\text { (Calabrese \& } \\
\text { Baldwin, 2003), } \\
\text { (Celso et al., 2011). }\end{array}$ & Anxiolytic Property & $\begin{array}{l}\text { Results revealed that the decoctions and infusion made } \\
\text { from the lemon grass revealed anxiolytic effects when they } \\
\text { are fed to animals. A light/ dark box test was conducted } \\
\text { and a biphasic dose response (U-shaped) curve was } \\
\text { reported. The anxiolytic effects of the extract followed the } \\
\text { GABAergic system signaling behaviour with established } \\
\text { anxiolytic drugs. It was therefore assumed that lemon grass } \\
\text { extract could be used for the treatment of ailments of the } \\
\text { central nervous system (CNS). }\end{array}$ \\
\hline $\begin{array}{l}\text { (Dharmendra } \text { et al., } \\
\text { 2001), } \\
\text { (Fandohan } \text { et al., } \\
\text { 2008), } \\
\text { Nguefacka et al., } \\
\text { 2012). }\end{array}$ & Antifungal Potential & $\begin{array}{l}\text { Research over the years tested on both edible and } \\
\text { pathogenic fungi revealed that the essential oil extracted } \\
\text { from lemon grass inhibited the growth of fungal cells } \\
\text { which are capable of secreting mycotoxins during storage } \\
\text { of food products as well as grains. The essential oil extract } \\
\text { has been reported to exhibit antifungal effects against both } \\
\text { disease causing and non-pathogenic fungi. The oil was } \\
\text { capable of inactivating disease-causing yeast cells } \\
\text { (Candida spp.) by inhibiting their growth. }\end{array}$ \\
\hline
\end{tabular}




\begin{tabular}{|c|c|c|}
\hline Author(s) & $\begin{array}{c}\text { Phytochemicals } \\
\text { (Active } \\
\text { Constituents) }\end{array}$ & $\begin{array}{c}\text { Description of Phytochemicals \& it's Biological } \\
\text { Activities }\end{array}$ \\
\hline $\begin{array}{l}\text { (Dash } \text { et al., 2017), } \\
\text { (Thawabteh } \text { et al., 2019), } \\
\text { (Vishette } \text { et al., 2019). }\end{array}$ & kkaloids & $\begin{array}{l}\text { Alkaloids are grouped into several classes based on their } \\
\text { heterocyclic ring system and biosynthetic precursor. It is } \\
\text { utilized in different areas due to its antimalarial, } \\
\text { antiasthma, anticancer, cholinomimetic, vasodilatory, } \\
\text { antiarrhythmic, analgesic and antibacterial responses. }\end{array}$ \\
\hline $\begin{array}{l}\text { (Dash } \text { et al., 2017), } \\
\text { (Vishette } \text { et al., 2019), } \\
\text { (Encyclopedia } \\
\text { Britannica, 2021), } \\
\text { (Science Direct, 2021). }\end{array}$ & Glycosides & $\begin{array}{l}\text { Glycosides are any variety of naturally occurring } \\
\text { substances with a carbohydrate portion, consisting of } \\
\text { one or more sugars or a uronic acid and is attached with } \\
\text { a hydroxy compound. It is used for its anticancer and } \\
\text { antiviral Responses. }\end{array}$ \\
\hline $\begin{array}{c}\text { (Dash et al., 2017), } \\
\text { (Krebihel, 2018), } \\
\text { (Vishette } \text { et al., 2019). }\end{array}$ & Tannins & $\begin{array}{l}\text { Tannins are a group of bitter and astringent compounds, } \\
\text { and they can be found abundantly in the wood, bark, } \\
\text { leaves and fruit of plants. It acts as potential metal ion } \\
\text { chelators; protein precipitating agents and it's works as } \\
\text { a biological antioxidant. }\end{array}$ \\
\hline $\begin{array}{l}\text { (Ali \& El-Annay, 2017), } \\
\text { (Trivedi et al., 2019), } \\
\text { (Vishette et al., 2019), } \\
\text { (Halver, 2020). }\end{array}$ & $\begin{array}{l}\text { Amino Acids \& } \\
\text { Proteins }\end{array}$ & $\begin{array}{l}\text { Amino acids are the monomers of structures known as } \\
\text { proteins and they are linked together through peptide } \\
\text { bonds. It possesses antibacterial and antifungal activities } \\
\text { and is used for the treatment of leprosy, eye problem, } \\
\text { epitaxies, intestinal worms, anorexia, biliousness and } \\
\text { skin ulcers. }\end{array}$ \\
\hline $\begin{array}{l}\text { (Dash et al., 2017), } \\
\text { (Vishette } \text { et al., 2019), } \\
\text { (Bahadur \& Chhetri, } \\
\text { 2020), } \\
\text { (Gunawardena, 2020). }\end{array}$ & Reducing Sugars & $\begin{array}{l}\text { A Reducing Sugar is a carbohydrate that is oxidized by } \\
\text { a weak oxidizing agent in basic aqueous solution. } \\
\text { Reducing sugars possesses antimicrobial and } \\
\text { antioxidant activities. It also aided in nutrient and } \\
\text { central signaling or as a regulatory molecule that } \\
\text { modulated gene expression that is related to growth, } \\
\text { development, metabolism, stress response, and even } \\
\text { disease resistance. }\end{array}$ \\
\hline
\end{tabular}




\begin{tabular}{|c|c|c|}
\hline $\begin{array}{c}\text { (Badam \& Bedekar, } \\
\text { 1993), } \\
\text { (Siqqidui \& Ali, 1997), } \\
\text { (Gunaherath, 2014), } \\
\text { (Cleveland Clinic, 2019), } \\
\text { (Vishette } \text { et al., 2019). }\end{array}$ & Phytosterols & $\begin{array}{l}\text { Phytosterols are also known as plant sterol and stanol } \\
\text { esters. They are a group of naturally occurring } \\
\text { compounds found in plant cell membranes. It is utilized } \\
\text { for many purposes such as: anticancer, antimicrobial, } \\
\text { anti-inflammatory, diuretic, anticholinesterase, } \\
\text { immunomodulatory, anabolic activities, antiviral } \\
\text { activities and anti-rheumatic responses. It was also } \\
\text { useful in treatment of syphilitic sores, earache boils, } \\
\text { nose trouble, wound healing, stomatitis and bad gum. }\end{array}$ \\
\hline $\begin{array}{c}\text { Badam \& Bedekar, } \\
\text { 1993), } \\
\text { (Dash et al., 2017), } \\
\text { (Vishette et al., 2019), } \\
\text { (Science Direct, 2021). }\end{array}$ & Saponins & $\begin{array}{l}\text { Saponins are a class of plant glycosides whereby } \\
\text { water-soluble sugars is attached to a lipophilic steroid } \\
\text { or triterpenoid. It possesses antiviral activities, anti- } \\
\text { inflammatory and anti-rheumatic responses. It is also } \\
\text { useful in the treatment of syphilitic sores, earache } \\
\text { boils, nose trouble, wound healing, stomatitis and bad } \\
\text { gum. }\end{array}$ \\
\hline $\begin{array}{c}\text { Badam \& Bedekar, } \\
\text { 1993), } \\
\text { (Subramanian \& } \\
\text { Lakshmana, 1996), } \\
\text { (Science Direct, 2021). }\end{array}$ & Triterpenes & $\begin{array}{l}\text { Triterpenes are also known as triterpenoids or } \\
\text { triterpenoid saponins. They are pentacyclic molecules } \\
\text { that are ultimately synthesized from isoprene. It } \\
\text { possesses antiviral activities, anti-inflammatory and } \\
\text { anti-rheumatic responses. It is also useful in the } \\
\text { treatment of syphilitic sores, earache boils, nose } \\
\text { trouble, wound healing, stomatitis and bad gum. }\end{array}$ \\
\hline $\begin{array}{l}\text { (Fujiwara } \text { et al., 1984), } \\
\text { (Badam \& Bedekar, } \\
\text { 1993), } \\
\text { (Roy \& Saraf, 2006). }\end{array}$ & $\begin{array}{c}\text { Limonoids (Phenolic } \\
\text { Diterpenoids) }\end{array}$ & $\begin{array}{l}\text { Limonoids are highly oxygenated and modified } \\
\text { terpenoids with a prototypical structure containing or } \\
\text { derived from a precursor with a 4,4,8-trimethyl-17- } \\
\text { furanylsteroid skeleton. It possesses insecticidal, insect } \\
\text { antifeedant and growth regulating activities on insects; } \\
\text { antiviral, antifungal and antibacterial activities, anti- } \\
\text { inflammatory, anti-rheumatic, anticancer and } \\
\text { Antimalarial responses. It is also useful in the treatment } \\
\text { of syphilitic sores, earache boils, nose trouble, wound } \\
\text { healing, stomatitis and bad gum. }\end{array}$ \\
\hline $\begin{array}{l}\text { (Fujiwara et al., 1984), } \\
\text { (Badam \& Bedekar, } \\
\text { 1993), } \\
\text { (Byju Classes, 2021). }\end{array}$ & Polysaccharides & $\begin{array}{l}\text { Polysaccharides are one of the most important and } \\
\text { major classes of the biomolecules. They are long chains } \\
\text { of carbohydrate molecules that are composed of several } \\
\text { smaller molecules known as monosaccharides. It }\end{array}$ \\
\hline
\end{tabular}




\begin{tabular}{|c|c|c|}
\hline & & $\begin{array}{l}\text { possesses antiviral activities, anti-inflammatory, anti- } \\
\text { rheumatic responses. It is also useful in treatment of } \\
\text { syphilitic sores, earache boils, nose trouble, wound } \\
\text { healing, stomatitis and bad gum. }\end{array}$ \\
\hline $\begin{array}{l}\text { (Singh \& Sastry, 1997), } \\
\text { (Siqqidui \& Ali, 1997), } \\
\text { (Kumar \& Pandey, } \\
\text { 2013), } \\
\text { (Dash et al., 2017). }\end{array}$ & Flavonoid & $\begin{array}{l}\text { Flavonoids are polyphenols on the basis flavin. They are } \\
\text { known as antioxidant and radical scavengers. It } \\
\text { possesses antibacterial and antifungal properties. }\end{array}$ \\
\hline $\begin{array}{l}\text { (Siqqidui \& Ali, 1997), } \\
\text { (Libre Text, 2020), } \\
\text { (Wu et al., 2020). }\end{array}$ & Terpenoid & $\begin{array}{l}\text { Terpenoids are also called Isoprenoids. They are a large } \\
\text { and diverse group of lipids which are derived from five- } \\
\text { carbon isoprene units and are assembled in thousands of } \\
\text { different combinations. It possesses } \\
\text { immunomodulatory, anti-inflammatory, antimicrobial, } \\
\text { antioxidant, and anticancer activities. }\end{array}$ \\
\hline $\begin{array}{c}\text { (Singh \& Sastry, 1997), } \\
\text { (Bhattacharya et al., } \\
\text { 2010), } \\
\text { (Pandey et al., 2014), } \\
\text { (Vishette et al., 2019). }\end{array}$ & Phenols & $\begin{array}{l}\text { Phenols are aromatic benzene ring compounds that } \\
\text { contains one or more hydroxyl groups and are produced } \\
\text { by plants mainly for protection against stress, plant } \\
\text { development, especially in lignin and pigment } \\
\text { biosynthesis. It also provides structural integrity and } \\
\text { scaffolding support to plants. It is useful in many } \\
\text { instances for its antibacterial and antifungal properties. } \\
\text { It also possesses antiviral activities, anti-inflammatory } \\
\text { and anti-rheumatic responses. It was also found to be } \\
\text { useful in the treatment of syphilitic sores, earache boils, } \\
\text { nose trouble, wound healing, stomatitis and bad gum. }\end{array}$ \\
\hline $\begin{array}{c}\text { (Pandey et al., 2014), } \\
\text { (Ali \& El-Annay, } \\
\text { 2017), } \\
\text { (Wilson, 2017), } \\
\text { (Trivedi et al., 2019). }\end{array}$ & Rutin & $\begin{array}{l}\text { Rutin is a bioflavonoid or a plant pigment, that is } \\
\text { found in some vegetables and fruits. It has powerful } \\
\text { antioxidant properties. It is use for the treatment of } \\
\text { leprosy, eye problem, epitaxies, intestinal worms, } \\
\text { anorexia, biliousness, helps the body produce } \\
\text { collagens, taken as a vitamin and skin ulcers. }\end{array}$ \\
\hline $\begin{array}{l}\text { (Ali, 1993), } \\
\text { (Singh \& Sastry, 1997), } \\
\text { (Kokate et al., 2010), } \\
\text { (Hossain et al., 2011), }\end{array}$ & Quercetin & $\begin{array}{l}\text { Quercetin is a natural flavonoid that is abundantly } \\
\text { found in vegetables and fruits. It is a pigment that } \\
\text { belongs to the group flavonoids. It is very active } \\
\text { against various pathogens. It also possesses }\end{array}$ \\
\hline
\end{tabular}




\begin{tabular}{|c|c|c|}
\hline $\begin{array}{l}\text { (Pandey et al., 2014), } \\
\text { (Science Direct, 2016), } \\
\text { (Ali \& El-Annay, } \\
\text { 2017), } \\
\text { (Trivedi et al., 2019). }\end{array}$ & & $\begin{array}{l}\text { antibacterial and antifungal properties. It is useful for } \\
\text { the treatment of leprosy, eye problem, epitaxies, } \\
\text { intestinal worms, anorexia, biliousness and skin ulcers. }\end{array}$ \\
\hline $\begin{array}{c}\text { (Pandey et al., 2014), } \\
\text { (Wilson, 2018). }\end{array}$ & Ellagic Acid & $\begin{array}{l}\text { Ellagic acid is a polyphenol or a micronutrient, found } \\
\text { in fruits and vegetables. It is well known for its } \\
\text { antioxidant, anti-inflammatory and anticancer } \\
\text { properties. }\end{array}$ \\
\hline $\begin{array}{l}\text { (Pandey et al., 2014), } \\
\text { (Carter, 2019), } \\
\text { (Science Direct, 2021). }\end{array}$ & Ferulic Acid & $\begin{array}{l}\text { Ferulic acid (FA) is a phenolic compound and it is a } \\
\text { major constituent of fruits and vegetables. Ferulic acid } \\
\text { is a strong antioxidant that works to boost the effects of } \\
\text { other antioxidants. It also has strong anti-inflammatory } \\
\text { properties. }\end{array}$ \\
\hline $\begin{array}{l}\text { (Singh \& Sastry, 1997), } \\
\text { (Pandey et al., 2014), } \\
\text { (Ali \& El-Annay, } \\
\text { 2017), } \\
\text { (Trivedi et al., 2019), } \\
\text { (WebMD, 2021). }\end{array}$ & $\begin{array}{l}\text { Beta-Sitosterol } \\
\text { (B-Sitosterol) }\end{array}$ & $\begin{array}{l}\text { Beta-Sitosterol is a substance found in plants. It is } \\
\text { found in the fruits, vegetables, nuts, and seeds and is } \\
\text { utilized in the making of medicine. It possesses } \\
\text { antibacterial and antifungal properties and is useful for } \\
\text { the treatment of leprosy, eye problems, epitaxies, } \\
\text { intestinal worms, anorexia, biliousness and skin ulcers. }\end{array}$ \\
\hline $\begin{array}{c}\text { (Saleem, 2009), } \\
\text { (Pandey et al., 2014). }\end{array}$ & Lupeol & $\begin{array}{l}\text { Lupeol is a triterpene and it is also known as } \\
\text { Fagarsterol. It serves as a multi-target agent with } \\
\text { immense anti-inflammatory potential that could target } \\
\text { key molecular pathways and it is very important for its } \\
\text { anticancer and anti-arthritic responses. }\end{array}$ \\
\hline $\begin{array}{c}\text { (Ali, 1993), } \\
\text { (Jones } \text { et al., 1994), } \\
\text { (Kokate et al., 2010), } \\
\text { (Hossain et al., 2011), } \\
\text { (Science Direct, 2021). }\end{array}$ & Azadirachtin & $\begin{array}{l}\text { Azadirachtin is an extract of fruit from the neem tree } \\
\text { and is the most active compound in neem. This is a } \\
\text { secondary metabolite, which is a chemical compound } \\
\text { that belongs to the limonoid group. It reduces insect } \\
\text { feeding on the plant and acts as a repellent and it is } \\
\text { also capable of interfering with insect hormones. It is } \\
\text { the most important of the phytochemicals present in } A \text {. } \\
\text { indica. This phytochemical has antimalarial activity. }\end{array}$ \\
\hline $\begin{array}{l}\text { (Sharma et al, 1959), } \\
\text { (Ali, 1993), } \\
\text { (Kokate et al., 2010), }\end{array}$ & Nimbin & $\begin{array}{l}\text { Nimbin is a limonoid compound found in neem. It has } \\
\text { a role as a plant metabolite and as a pesticide. It is } \\
\text { active against various pathogens and it is also use as a }\end{array}$ \\
\hline
\end{tabular}




\begin{tabular}{|c|c|c|}
\hline $\begin{array}{l}\text { (Hossain et al., 2011), } \\
\text { (Ali \& El-Annay, } \\
\text { 2017), } \\
\text { (Trivedi et al., 2019), } \\
\text { (Pub Chem, 2021). }\end{array}$ & & $\begin{array}{l}\text { spermicide. Other uses usually include: the relieve of } \\
\text { intestinal worm and leprosy and it is also use for } \\
\text { analgesic and as an alternative antipyretic. }\end{array}$ \\
\hline $\begin{array}{c}\text { (Ali, 1993), } \\
\text { (Kokate } \text { et al., 2010), } \\
\text { (Hossain } \text { et al., 2011), } \\
\text { (Ali \& El-Annay, 2017), } \\
\text { (Trivedi et al., 2019), } \\
\text { (Science Direct, 2021). }\end{array}$ & Salannin & $\begin{array}{l}\text { Salannin is a limonoid compound with strong } \\
\text { insecticidal activity. It plays a role as an insect growth } \\
\text { regulator, an antifeedant and a plant metabolite. It is } \\
\text { very active against various types of pathogens and is } \\
\text { used to relieve intestinal worm and leprosy. }\end{array}$ \\
\hline $\begin{array}{l}\text { (Ali, 1993), } \\
\text { (Kokate } \text { et al., 2010), } \\
\text { (Hossain } \text { et al., 2011), } \\
\text { (Ali \& El-Annay, 2017), } \\
\text { (Science Direct, 2017). }\end{array}$ & Gedunin & $\begin{array}{l}\text { Gedunin is a limonoid derived from neem and is a } \\
\text { pentacyclic triterpenoid natural product. It is very } \\
\text { active against various pathogens. It possesses } \\
\text { antifungal, antimalarial and anticancer properties and } \\
\text { serves as an antineoplastic agent. }\end{array}$ \\
\hline $\begin{array}{l}\text { (Ali, 1993), } \\
\text { (Kokate et al., 2010), } \\
\text { (Hossain et al., 2011), } \\
\text { (Alzohairy, 2016). }\end{array}$ & Nimbolinin & $\begin{array}{l}\text { Nimbolinin is an important component of neem and it } \\
\text { is very active against various pathogens. It is a } \\
\text { powerful antioxidant and it plays an integral role in } \\
\text { diseases management through the modulation of } \\
\text { various genetic pathways. }\end{array}$ \\
\hline $\begin{array}{l}\text { (Ali, 1993), } \\
\text { (Kokate } \text { et al., 2010), } \\
\text { (Hossain } \text { et al., 2011). }\end{array}$ & Sodium Nimbinate & $\begin{array}{l}\text { Sodium Nimbinate is an important component of neem } \\
\text { and it is very active against various pathogens and it } \\
\text { also acts as a spermicide and produce diuretic, anti- } \\
\text { arthritic and anti-inflammatory responses. }\end{array}$ \\
\hline $\begin{array}{c}\text { (Ali, 1993), } \\
\text { (Kokate et al., 2010), } \\
\text { (Hossain et al., 2011), } \\
\text { (Alzohairy, 2016), } \\
\text { (Ali \& El-Annay, } \\
\text { 2017). }\end{array}$ & Nimbanene & $\begin{array}{l}\text { Nimbanene is an important component of neem and it } \\
\text { is very active against various pathogens. It is a } \\
\text { powerful antioxidant and it plays an integral role in } \\
\text { diseases management through the modulation of } \\
\text { various genetic pathways. }\end{array}$ \\
\hline $\begin{array}{l}\text { (Ali, 1993), } \\
\text { (Kokate et al., 2010), } \\
\text { (Hossain } \text { et al., 2011), } \\
\text { (Pub Chem, 2021). }\end{array}$ & Ascorbic Acid & $\begin{array}{l}\text { Ascorbic Acid is commonly known as Vitamin C. It is } \\
\text { a natural water-soluble vitamin. Ascorbic acid acts as a } \\
\text { potent reducing and antioxidant agent which function } \\
\text { in the fighting off certain types of different bacterial } \\
\text { infections, detoxifying reactions and the formation of }\end{array}$ \\
\hline
\end{tabular}




\begin{tabular}{|c|c|c|}
\hline & & $\begin{array}{l}\text { collagen in fibrous tissues, teeth, bones, connective } \\
\text { tissue, skin, and capillaries. It also possesses } \\
\text { antioxidant and antitumor activities. }\end{array}$ \\
\hline $\begin{array}{l}\text { (Ali, 1993), } \\
\text { (Kokate } \text { et al., 2010), } \\
\text { (Hossain } \text { et al., 2011), } \\
\text { (Trivedi et al., 2019). }\end{array}$ & Nimbiol & $\begin{array}{l}\text { Nimbiol is an important component of neem and it is } \\
\text { very active against various pathogens. It is also useful } \\
\text { for analgesic potential and as an alternative antipyretic. }\end{array}$ \\
\hline $\begin{array}{c}\text { (Ali, 1993), } \\
\text { (Kokate } \text { et al., 2010), } \\
\text { (Hossain et al., 2011), } \\
\text { (Ali \& El-Annay, 2017), } \\
\text { (Trivedi et al., 2019). }\end{array}$ & $\begin{array}{c}6- \\
\text { Desacetylnimbinene }\end{array}$ & $\begin{array}{l}\text { 6-Desacetylnimbinene is an important component of } \\
\text { neem and it is very active against various pathogens. It } \\
\text { is use for its Analgesic and as alternative Antipyretic. It } \\
\text { is also use for the treatment of leprosy, eye problem, } \\
\text { epitaxies, intestinal worms, anorexia, biliousness and } \\
\text { skin ulcers. }\end{array}$ \\
\hline $\begin{array}{c}\text { (Ali, 1993), } \\
\text { (Kokate } \text { et al., 2010), } \\
\text { (Hossain et al., 2011). }\end{array}$ & Nimbandiol & $\begin{array}{l}\text { Nimbandiol is an important component of neem and it } \\
\text { was very active against various pathogens. }\end{array}$ \\
\hline $\begin{array}{l}\text { (Ali, 1993), } \\
\text { (Kokate et al., 2010), } \\
\text { (Hossain et al., 2011), } \\
\text { (Paddock, 2016), } \\
\text { (Ali \& El-Annay, 2017), } \\
\text { (Trivedi et al., 2019). }\end{array}$ & Nimbolide & $\begin{array}{l}\text { Nimbolide is a natural extract that is derived from the } \\
\text { leaves and flowers of the neem tree. It is very active } \\
\text { against various pathogens. It is use for its Analgesic, } \\
\text { Anticancer and as an alternative Antipyretic. It is also } \\
\text { use for the treatment of leprosy, eye problem, epitaxies, } \\
\text { intestinal worms, anorexia, biliousness and skin ulcers. }\end{array}$ \\
\hline $\begin{array}{c}\text { (Ali, 1993), } \\
\text { (Kokate et al., 2010), } \\
\text { (Hossain } \text { et al., 2011). }\end{array}$ & $\begin{array}{c}\text { 1-Hexacosanol } \\
\text { (n-Hexacosanol), } \\
\text { 7-Desacetyl-7- } \\
\text { Benzoylazadiradione, } \\
\text { 7-Desacetyl-7- } \\
\text { Benzoylgedunin } \\
\text { \& } \\
\text { 17- } \\
\text { Hydroxyazadiradione }\end{array}$ & $\begin{array}{l}\text { 1-Hexacosanol, 7-Desacetyl-7-Benzoylazadiradione, 7- } \\
\text { Desacetyl-7-Benzoylgedunin and } \\
\text { Hydroxyazadiradione is an important component of } \\
\text { neem and it was very active against various pathogens. }\end{array}$ \\
\hline $\begin{array}{l}\text { (Sharma \& Sakena, } \\
\text { 1959). }\end{array}$ & Mahmoodin & $\begin{array}{l}\text { Mahmoodin is an important component of neem and it } \\
\text { possess antibacterial activities. }\end{array}$ \\
\hline (Biswa et al., 2002). & $\begin{array}{l}\text { Margolone, } \\
\text { Mergolonone, } \\
\text { Isomergolonone }\end{array}$ & $\begin{array}{l}\text { Margolone is an active phytochemical present in neem } \\
\text { and it possesses antibacterial activities, anti- } \\
\text { inflammatory and immunomodulatory. }\end{array}$ \\
\hline
\end{tabular}




\begin{tabular}{|c|c|c|}
\hline & $\begin{array}{c}\& \\
\text { NB-2 Peptidoglycan }\end{array}$ & $\begin{array}{l}\text { Mergolonone is an active phytochemical present in } \\
\text { neem and it possesses antibacterial, antifungal and anti- } \\
\text { dermal activities. } \\
\text { Isomergolonone is an active phytochemical present in } \\
\text { neem and it possesses antibacterial, antifungal and anti- } \\
\text { dermal activities. } \\
\text { NB-2 Peptidoglycan is present in the stem and bark of } \\
\text { the neem plant. Its major biological activity is mainly } \\
\text { immunomodulatory related. }\end{array}$ \\
\hline $\begin{array}{l}\text { (Bhargava et al., 1970), } \\
\text { (Kaur et al., 2004). }\end{array}$ & Nimbidin & $\begin{array}{l}\text { Nimbidin is a mixture of tetranortriterpenes and it is the } \\
\text { major active compound of the seed oil of Azadirachta } \\
\text { indica. It possesses many potent biological activities } \\
\text { such as: anti-inflammatory and antiarthritic activities. }\end{array}$ \\
\hline $\begin{array}{l}\text { (Ali \& El-Annay, 2017), } \\
\text { (Science Direct, 2021). }\end{array}$ & Meliacin & $\begin{array}{l}\text { Meliacin is an active phytochemical present in neem } \\
\text { and it possess antipyretic activity and also use to treat } \\
\text { hypoglycemic anti-gastric ulcers. }\end{array}$ \\
\hline (Ali \& El-Annay, 2017). & Valassin & $\begin{array}{l}\text { Valassin is an active phytochemical present in neem and } \\
\text { it possesses antimicrobial and insecticidal activities. }\end{array}$ \\
\hline $\begin{array}{l}\text { (Chen \& Chen, 2013), } \\
\text { (Ali \& El-Annay, 2017), } \\
\text { (Trivedi et al., 2019). }\end{array}$ & Kaempferol & $\begin{array}{l}\text { Kaempferol is a polyphenol antioxidant found in neem. } \\
\text { It also possesses anti-inflammatory response. It is also } \\
\text { use for the treatment of leprosy, eye problem, epitaxies, } \\
\text { intestinal worms, anorexia, biliousness and skin ulcers. }\end{array}$ \\
\hline $\begin{array}{l}\text { (Ali \& El-Annay, 2017), } \\
\text { (Trivedi et al., 2019). }\end{array}$ & $\begin{array}{l}\text { Quercetin-3- } \\
\text { Galactocide } \\
\text { (Hperin) }\end{array}$ & $\begin{array}{l}\text { Quercetin-3-Galactocide is an important component of } \\
\text { neem and it is use for the treatment of leprosy, eye } \\
\text { problem, epitaxies, intestinal worms, anorexia, } \\
\text { biliousness and skin ulcers. }\end{array}$ \\
\hline $\begin{array}{l}\text { (Ali \& El-Annay, } \\
\text { 2017), } \\
\text { (Trivedi et al., 2019), } \\
\text { (Phytochemicals, 2021), }\end{array}$ & Isorhamnetin & $\begin{array}{l}\text { Isorhamnetin is a flavonoid, which occurs naturally in } \\
\text { plants and it is also a metabolite of quercetin. It is use } \\
\text { for the treatment of leprosy, eye problem, epitaxies, } \\
\text { intestinal worms, anorexia, biliousness and skin ulcers. }\end{array}$ \\
\hline $\begin{array}{l}\text { (Ali \& El-Annay, } \\
\text { 2017), } \\
\text { (Trivedi et al., 2019). }\end{array}$ & Vilasinin & $\begin{array}{l}\text { Vilasinin is an active phytochemical present in neem } \\
\text { and it is use for the treatment of leprosy, eye problem, } \\
\text { epitaxies, intestinal worms, anorexia, biliousness and } \\
\text { skin ulcers. }\end{array}$ \\
\hline $\begin{array}{l}\text { (Ali \& El-Annay, } \\
\text { 2017), }\end{array}$ & $\begin{array}{l}\text { Nimocinol } \\
\text { (6a-hydroxy- }\end{array}$ & $\begin{array}{l}\text { Nimocinol is an active phytochemical present in neem } \\
\text { and it is use for the treatment of leprosy, eye problem, }\end{array}$ \\
\hline
\end{tabular}




\begin{tabular}{|c|c|c|}
\hline (Trivedi et al., 2019). & azadirone) & $\begin{array}{l}\text { epitaxies, intestinal worms, anorexia, biliousness and } \\
\text { skin ulcers. }\end{array}$ \\
\hline $\begin{array}{l}\text { (Ali \& El-Annay, } \\
\text { 2017), } \\
\text { (Trivedi et al., 2019), } \\
\text { (Pub Chem, 2021). }\end{array}$ & Sugiol & $\begin{array}{l}\text { Sugiol is an abietane diterpenoid that is a ferruginol in } \\
\text { which the methylene group is para to the phenolic } \\
\text { hydroxy group and has been substituted by an oxo } \\
\text { group. It acts as a plant metabolite, an antiviral agent, } \\
\text { an antineoplastic agent, an antioxidant and a radical } \\
\text { scavenger. It is also use for its analgesic and as } \\
\text { alternative antipyretic. }\end{array}$ \\
\hline $\begin{array}{l}\text { (Ali \& El-Annay, } \\
\text { 2017). }\end{array}$ & Nimbolin A and B & $\begin{array}{l}\text { Nimbolin A and B are two new meliacin cinnamates } \\
\text { from Azadirachta indica } L \text {. It is use for its antifeedant } \\
\text { activity against insects. }\end{array}$ \\
\hline $\begin{array}{l}\text { (Ali \& El-Annay, } \\
\text { 2017), } \\
\text { (Pub Chem, 2021). }\end{array}$ & $\begin{array}{l}\text { Astragalin } \\
\text { (Kaemferol-3- } \\
\text { Glucoside) }\end{array}$ & $\begin{array}{l}\text { Astragalin is also called Kaemferol-3-Glucoside and it } \\
\text { is an active phytochemical present in neem and it plays } \\
\text { a role as a trypanocidal drug and a plant metabolite. }\end{array}$ \\
\hline $\begin{array}{l}\text { (Ali \& El-Annay, } \\
\text { 2017), } \\
\text { (Trivedi et al., 2019). }\end{array}$ & Meliantriol & $\begin{array}{l}\text { Meliantriol is an active phytochemical present in neem } \\
\text { and it is use to relieve intestinal worm and leprosy. }\end{array}$ \\
\hline $\begin{array}{l}\text { (Ali \& El-Annay, } \\
\text { 2017), } \\
\text { (Trivedi et al., 2019). }\end{array}$ & $\begin{array}{l}\text { B-Sitosterol- } \beta \text {-D- } \\
\text { Glucoside }\end{array}$ & $\begin{array}{l}\text { B-Sitosterol- } \beta \text {-D-Glucoside is an active phytochemical } \\
\text { present in neem and it is use for the treatment of } \\
\text { leprosy, eye problem, epitaxies, intestinal worms, } \\
\text { anorexia, biliousness and skin ulcers. }\end{array}$ \\
\hline $\begin{array}{l}\text { (Lochnit et al., 1997), } \\
\text { (Ali \& El-Annay, } \\
\text { 2017). }\end{array}$ & $\begin{array}{l}\text { Tigenic Acid } \\
\text { (Methyl 1-2 } \\
\text { Butanoic Acid) }\end{array}$ & $\begin{array}{l}\text { Methyl 1-2 Butanoic Acid is also known as Tigenic } \\
\text { Acid. It is well known to be an inhibitor in cytokine } \\
\text { synthesis. }\end{array}$ \\
\hline $\begin{array}{l}\text { (Semwal et al., 2016), } \\
\text { (Ali \& El-Annay, } \\
\text { 2017). }\end{array}$ & Myricetin & $\begin{array}{l}\text { Myricetin is a common plant-derived flavonoid and it } \\
\text { is well known for its nutraceuticals value. This } \\
\text { compound exhibits a wide range of activities such as: } \\
\text { an antioxidant, anticancer, antidiabetic and anti- } \\
\text { inflammatory activities. }\end{array}$ \\
\hline $\begin{array}{l}\text { (Ali \& El-Annay, } \\
\text { 2017), } \\
\text { (Research Gate, 2021). }\end{array}$ & Melicitrin & $\begin{array}{l}\text { Melicitrin is an flavanol glycoside found in neem. It } \\
\text { possesses strong anticancer property. }\end{array}$ \\
\hline $\begin{array}{l}\text { (Ali \& El-Annay, } \\
\text { 2017) }\end{array}$ & Nimbinene & $\begin{array}{l}\text { Nimbin is a triterpenoid compound found in neem and } \\
\text { it is use for analgesic and as alternative antipyretic. }\end{array}$ \\
\hline
\end{tabular}




\begin{tabular}{|c|c|c|}
\hline (Trivedi et al., 2019). & & \\
\hline $\begin{array}{l}\text { (Ali \& El-Annay, } \\
\text { 2017), } \\
\text { (Trivedi et al., 2019). }\end{array}$ & $\begin{array}{l}\text { Nimbidic Acid } \\
\text { (Salannic Acid) }\end{array}$ & $\begin{array}{l}\text { Nimbidic Acid is an active phytochemical present in } \\
\text { neem and it is use to relieve intestinal worm and } \\
\text { leprosy. }\end{array}$ \\
\hline $\begin{array}{l}\text { (Ali \& El-Annay, } \\
\qquad 2017) \\
\text { (Trivedi et al., 2019). }\end{array}$ & Azadirone & $\begin{array}{l}\text { Azadirone is a limonoid tetranortriterpenes compound } \\
\text { use to relieve intestinal worm and leprosy. }\end{array}$ \\
\hline $\begin{array}{l}\text { (Ali \& El-Annay, 2017), } \\
\text { (Trivedi et al., 2019). }\end{array}$ & $\begin{array}{l}\text { 5-Hydroxy-Methyl } \\
\text { Furfural }\end{array}$ & $\begin{array}{l}\text { 5-Hydroxy-Methyl Furfural is an active compound in } \\
\text { neem and is used to relieve piles, intestinal worms, } \\
\text { urinary disorders, epistaxis, phlegm, eye problem, } \\
\text { diabetes, wounds and leprosy. }\end{array}$ \\
\hline $\begin{array}{l}\text { (Ali \& El-Annay, 2017), } \\
\text { (Trivedi et al., 2019). }\end{array}$ & Nimolicin & $\begin{array}{l}\text { Nimolicin is an active compound in neem and is used to } \\
\text { relieve piles, intestinal worms, urinary disorders, } \\
\text { epistaxis, phlegm, eye problem, diabetes, wounds and } \\
\text { leprosy. }\end{array}$ \\
\hline $\begin{array}{l}\text { (Ali \& El-Annay, 2017), } \\
\text { (Trivedi et al., 2019). }\end{array}$ & Nomolin & $\begin{array}{l}\text { Nomolin is an active compound in neem and is use to } \\
\text { relieve piles, intestinal worms, urinary disorders, } \\
\text { epistaxis, phlegm, eye problem, diabetes, wounds and } \\
\text { leprosy. }\end{array}$ \\
\hline $\begin{array}{l}\text { (Ali \& El-Annay, 2017), } \\
\text { (Trivedi et al., 2019). }\end{array}$ & $\begin{array}{l}17 \beta- \\
\text { Hydroxyazadiradione } \\
\& \\
\text { 17-epi-azadiradione }\end{array}$ & $\begin{array}{l}17 \beta \text {-Hydroxyazadiradione is an active compound in } \\
\text { neem and is used to relieve piles, intestinal worms, } \\
\text { urinary disorders, epistaxis, phlegm, eye problem, } \\
\text { diabetes, wounds and leprosy. }\end{array}$ \\
\hline $\begin{array}{c}\text { (Journal of } \\
\text { Complementary and } \\
\text { Alternative Medicinal } \\
\text { Research, 2019), } \\
\text { (Science Direct, 2021). }\end{array}$ & Anthraquinone & $\begin{array}{l}\text { Anthraquinones are aromatic organic compounds. It is } \\
\text { also referred to as anthracenedione or dioxoanthracene. } \\
\text { It exhibits many biological activities including: anti- } \\
\text { inflammatory, antiviral, antimicrobial, and anticancer } \\
\text { effects. }\end{array}$ \\
\hline
\end{tabular}

Table Five (5) showing the Phytochemical Composition of Ocimum tenuiflorum

\begin{tabular}{|c|c|c|}
\hline Author(s) & $\begin{array}{c}\text { Phytochemicals } \\
\text { (Active } \\
\text { Constituents) }\end{array}$ & Description of Phytochemicals/ Biological Activities \\
\hline $\begin{array}{c}\text { (Siddique \& Ali, 1997)' } \\
\text { (Thawabteh } \text { et al., 2019). }\end{array}$ & Alkaloid & $\begin{array}{c}\text { Alkaloids are grouped into several classes based on their } \\
\text { heterocyclic ring system and biosynthetic precursor. It is }\end{array}$ \\
\hline
\end{tabular}




\begin{tabular}{|c|c|c|}
\hline & & $\begin{array}{l}\text { utilized in different areas due to its antimalarial, } \\
\text { antiasthma, anticancer, cholinomimetic, vasodilatory, } \\
\text { antiarrhythmic, analgesic and antibacterial responses. }\end{array}$ \\
\hline $\begin{array}{l}\text { (Siddique \& Ali, 1997), } \\
\text { (Encyclopedia Britannica, } \\
\text { 2021), } \\
\text { (Science Direct, 2021). }\end{array}$ & Glycoside & $\begin{array}{l}\text { Glycosides are any variety of naturally occurring } \\
\text { substances with a carbohydrate portion, consisting of one } \\
\text { or more sugars or a uronic acid and is attached with a } \\
\text { hydroxy compound. It is use for its anticancer and } \\
\text { antiviral responses. }\end{array}$ \\
\hline $\begin{array}{l}\text { (Siddique \& Ali, 1997), } \\
\text { (Libre Text, 2020), } \\
\text { (Wu et al., 2020). }\end{array}$ & Terpenoid & $\begin{array}{l}\text { Terpenoids are also called Isoprenoids and they are a large } \\
\text { and diverse group of lipids which are derived from five- } \\
\text { carbon isoprene units and are assembled in thousands of } \\
\text { different combinations. They possess strong } \\
\text { immunomodulatory, anti-inflammatory, antimicrobial, } \\
\text { antioxidant and anticancer activities. }\end{array}$ \\
\hline $\begin{array}{l}\text { (Siddique \& Ali, 1997), } \\
\text { (Gunaherath, 2014), } \\
\text { (Cleveland Clinic, 2019). }\end{array}$ & Steroid & $\begin{array}{l}\text { Steroids are a group of naturally occurring compounds } \\
\text { found in plant cell membranes. They are utilized for many } \\
\text { purposes such as: anticancer, antimicrobial, anti- } \\
\text { inflammatory, diuretic, anticholinesterase, } \\
\text { immunomodulatory, anabolic activities, antiviral activities } \\
\text { and anti-Rheumatic responses. It is also useful in the } \\
\text { treatment of syphilitic sores, earache boils, nose trouble, } \\
\text { wound healing, stomatitis and bad gum. }\end{array}$ \\
\hline $\begin{array}{l}\text { (Siddique \& Ali, 1997), } \\
\text { (Cushnie \& Lamb, 2005), } \\
\text { (Kumar \& Pandey, 2013). }\end{array}$ & Flavonoid & $\begin{array}{l}\text { Flavonoids are polyphenols on the basis flavin. They are } \\
\text { known as antioxidant and radical scavengers. It has anti- } \\
\text { inflammatory and antibacterial characteristics. }\end{array}$ \\
\hline $\begin{array}{c}\text { (Siddique \& Ali, 1997), } \\
\text { (Krebihel, 2018). }\end{array}$ & Tannins & $\begin{array}{l}\text { Tannins are a group of bitter and astringent compounds } \\
\text { and they can be found abundantly in the wood, bark, } \\
\text { leaves and fruit of plants. It acts as potential metal ion } \\
\text { chelators, protein precipitating agents, and works as a } \\
\text { biological antioxidant. }\end{array}$ \\
\hline $\begin{array}{l}\text { (Siddique \& Ali, 1997), } \\
\text { (Bahadur \& Chhetri, } \\
\text { 2020), } \\
\text { (Gunawardena, 2020). }\end{array}$ & Reducing Sugar & $\begin{array}{l}\text { A Reducing sugar is a carbohydrate that is oxidized by a } \\
\text { weak oxidizing agent in basic aqueous solution. Reducing } \\
\text { sugars possess antimicrobial and antioxidant activities. It } \\
\text { also aids in nutrient and central signaling or as a } \\
\text { regulatory molecule that modulate gene expression that is } \\
\text { related to growth, development, metabolism, stress } \\
\text { response, and even disease resistance. }\end{array}$ \\
\hline
\end{tabular}




\begin{tabular}{|c|c|c|}
\hline $\begin{array}{l}\text { (Ansari, 2015), } \\
\text { (Mlala et al., 2019), } \\
\text { (Science Direct, 2021). }\end{array}$ & Ursolic Acid & $\begin{array}{l}\text { Ursolic Acid is a pentacyclic triterpenoid compound found } \\
\text { in many herbs and spices. It is beneficial for its anti- } \\
\text { inflammatory, Anticancer, antidiabetic, antioxidant and } \\
\text { antibacterial effects. }\end{array}$ \\
\hline $\begin{array}{c}\text { (Ansari, 2015), } \\
\text { (Ayeleso et al., 2017). }\end{array}$ & Oleanolic Acid & $\begin{array}{l}\text { Oleanolic Acid is a pentacyclic triterpenoid that is a } \\
\text { natural occurring product that has been isolated from } \\
\text { several food and medicinal plants. It possesses strong } \\
\text { antimicrobial activity against a wide range of pathogens } \\
\text { and it is also used by human beings for antibiotic therapy. }\end{array}$ \\
\hline $\begin{array}{c}\text { (Ansari, 2015), } \\
\text { (Amoah et al., 2016). }\end{array}$ & Rosmarinic Acid & $\begin{array}{l}\text { It is a water-soluble phenolic compound and an ester of } \\
\text { caffeic acid. It is known for its strong antioxidant, } \\
\text { antimicrobial anti-inflammatory activities. }\end{array}$ \\
\hline $\begin{array}{l}\text { (Singh } \text { et al., 1996), } \\
\text { (Machado et al., 1999), } \\
\text { (Awashti \& Dixit, 2007), } \\
\text { (Vyas, 2012), } \\
\text { (Ansari, 2015), } \\
\text { (Yamani et al., 2016), } \\
\text { (Borah \& Biswas, 2018). }\end{array}$ & Eugenol & $\begin{array}{l}\text { Eugenol is a weakly acidic phenolic compound and it } \\
\text { provides anti-Inflammatory, antiarthritic, antistress and } \\
\text { antipyretic responses. It also possesses antioxidant, } \\
\text { anticancer, acaricide, antispasmodic, antibacterial, } \\
\text { antiviral and insecticidal properties. }\end{array}$ \\
\hline $\begin{array}{l}\text { (Cusnu \& Basar, 2008), } \\
\quad \text { (Ansari, 2015), } \\
\text { (Science Direct, 2021). }\end{array}$ & Carvacrol & $\begin{array}{l}\text { Carvacrol is a phenolic monoterpenoid compound of } \\
\text { many aromatic plants. It is very useful for many beneficial } \\
\text { reasons such as: antimicrobial, antitumor, antimutagenic, } \\
\text { antigenotoxic, angiogenic, analgesic, antispasmodic, anti- } \\
\text { inflammatory, antiparasitic, antiplatelet, AChe inhibitory, } \\
\text { antielastase, insecticidal, antihepatotoxic and } \\
\text { aepatoprotective activities and used as feed additive. }\end{array}$ \\
\hline $\begin{array}{l}\text { (Kicel } \text { et al., 2005), } \\
\text { (Kamatou \& Viljoen, } \\
\text { 2008), } \\
\text { (Khan et al., 2010), } \\
\text { (Ansari, 2015), } \\
\text { (Yamani et al., 2016), } \\
\text { (Science Direct, 2017). }\end{array}$ & Linalool & $\begin{array}{l}\text { Linalool is a noncyclic monoterpenoid that is commonly } \\
\text { extracted from tulsi. It is a colorless liquid with a spicy } \\
\text { herbal odor. It possesses antimicrobial, anticancer, anti- } \\
\text { inflammatory, antioxidant properties and it have various } \\
\text { effects on the central nervous system. }\end{array}$ \\
\hline $\begin{array}{l}\text { (Brophy et al., 1993), } \\
\text { (Bhattacharya et al., } \\
\text { 1996), } \\
\text { (Kothari et al., 2005), }\end{array}$ & $\begin{array}{c}\text { Beta } \\
\text { Caryophyllene } \\
(\beta \text {-Caryophyllene) }\end{array}$ & $\begin{array}{l}\text { Beta Caryophyllene is a natural bicyclic sesquiterpene that } \\
\text { is a constituent of many essential oils. It demonstrates } \\
\text { selective antibacterial activity, anti-fungal activity and } \\
\text { strong antioxidant effects. }\end{array}$ \\
\hline
\end{tabular}




\begin{tabular}{|c|c|c|}
\hline $\begin{array}{l}\text { (Awashti \& Dixit, 2007), } \\
\text { (Ansari, 2015), } \\
\text { (Dahham et al., 2015), } \\
\text { (Yamani et al., 2016), } \\
\text { (Science Direct, 2021). }\end{array}$ & & \\
\hline $\begin{array}{l}\text { (Machado et al., 1999), } \\
\text { (Awashti \& Dixit, 2007), } \\
\text { (Ansari, 2015), } \\
\text { (Yamani et al., 2016), } \\
\text { (Xie et al., 2020), } \\
\text { (Science Direct, 2021). }\end{array}$ & $\begin{array}{l}\text { Beta Elemene } \\
(\beta \text {-Elemene })\end{array}$ & $\begin{array}{l}\text { Beta Elemene is a sesquiterpene compound extracted from } \\
\text { certain herbs. It has direct antitumor effects, arresting the } \\
\text { cell cycle, inhibiting angiogenesis and cell migration, } \\
\text { enhancing the immunogenicity of tumor cells, promoting } \\
\text { erythrocyte immune function, and inhibiting cancer. }\end{array}$ \\
\hline $\begin{array}{c}\text { (Ansari, 2015), } \\
\text { (Science Direct, 2021). }\end{array}$ & Germacrene & $\begin{array}{l}\text { Germacrene is a terpene that is produced by a number of } \\
\text { plant species and it attracts different types of insects. It } \\
\text { possesses antimicrobial, antioxidative and even anti- } \\
\text { inflammatory activity. }\end{array}$ \\
\hline $\begin{array}{l}\text { (Bhattacharya et al., } \\
\text { 1996), } \\
\text { (Kothari et al., 2005), } \\
\text { (Awashti \& Dixit, 2007), } \\
\text { (Gbolade \& Lockwood, } \\
\text { 2008), } \\
\text { (Science Direct, 2021). }\end{array}$ & Methyl Eugenol & $\begin{array}{l}\text { Methyl eugenol is also known as allylveratrol. It is a } \\
\text { natural chemical compound classified as a phenylpropene } \\
\text { and it is methyl ether of eugenol and it plays an important } \\
\text { role in insect behavior and pollination. It also possesses } \\
\text { significant antimicrobial activity. }\end{array}$ \\
\hline $\begin{array}{l}\text { (Brophy et al., 1993), } \\
\text { (Khan et al., 2010), } \\
\text { (Avetisyan et al., 2017). }\end{array}$ & $\begin{array}{l}\text { Methyl Chavicol } \\
\text { (Estragole) }\end{array}$ & $\begin{array}{l}\text { Methyl Chavicol is also known as Estragole. It is a natural } \\
\text { organic compound and is classified as a phenylpropene. It } \\
\text { possesses antioxidant and antimicrobial activities. }\end{array}$ \\
\hline $\begin{array}{l}\text { (Kicel et al., 2005), } \\
\text { (Kazemi \& Rostami, } \\
\text { 2015). }\end{array}$ & $\beta$-Bisabolene & $\begin{array}{l}\beta \text {-Bisabolene is an active compound in tulsi and possesses } \\
\text { antioxidant properties and antimicrobial activity. }\end{array}$ \\
\hline $\begin{array}{l}\text { (Kicel et al., 2005), } \\
\text { (Obeng-Ofari et al., } \\
\text { 2009). }\end{array}$ & 1, 8-Cineole & $\begin{array}{l}\text { 1, 8-Cineole is an active compound in tulsi and it } \\
\text { possesses repellent, toxicant and antimicrobial activities. }\end{array}$ \\
\hline $\begin{array}{l}\text { (Gbolade \& Lockwood, } \\
\text { 2008), } \\
\text { (Sitarek, 2017). }\end{array}$ & Isocaryophyllene & $\begin{array}{l}\text { Isocaryophyllene is an active compound in tulsi and it } \\
\text { possesses many activities such as: antibacterial, } \\
\text { antioxidant, antiproliferative and anti-Inflammatory } \\
\text { properties. }\end{array}$ \\
\hline (Machado et al., 1999), & Caryophyllene & Caryophyllene oxide is a bicyclic sesquiterpene and \\
\hline
\end{tabular}




\begin{tabular}{|c|c|c|}
\hline $\begin{array}{l}\text { (Yamani et al., 2016), } \\
\text { (Pub Chem, 2021). }\end{array}$ & Oxide & $\begin{array}{l}\text { metabolite of } \beta \text {-Caryophyllene. It possesses many } \\
\text { important properties such as: antimicrobial, antioxidative, } \\
\text { anticarcinogenic, anti-inflammatory, and even analgesic } \\
\text { activities. }\end{array}$ \\
\hline $\begin{array}{l}\text { (Brophy et al., 1993), } \\
\text { (Da Silva et al., 2016), } \\
\text { (Yamani et al., 2016). }\end{array}$ & Camphor & $\begin{array}{l}\text { Camphor is an organic terpene compound that is } \\
\text { commonly use in in many products making. It possesses } \\
\text { antiviral, antimicrobial, antitussive, and analgesic } \\
\text { properties. }\end{array}$ \\
\hline (Kashyap et al., 2011). & $\begin{array}{c}\text { Trans- } \\
\text { Caryophyllene }\end{array}$ & $\begin{array}{l}\text { Trans-Caryophyllene is an active compound in tulsi. It } \\
\text { exerted effects on various tissues e.g., bone tissue and also } \\
\text { has antibacterial effects. }\end{array}$ \\
\hline $\begin{array}{l}\text { (Kashyap et al., 2011); } \\
\text { (Yamani et al., 2016), } \\
\text { (American Chemical } \\
\text { Society, 2021). }\end{array}$ & Camphene & $\begin{array}{l}\text { Camphene is a monoterpene with a bicyclic skeleton that } \\
\text { occurs in one or both of its enantiomeric forms in a variety } \\
\text { of essential oils. It possesses antioxidant and antimicrobial } \\
\text { activities. }\end{array}$ \\
\hline $\begin{array}{c}\text { (Kashyap et al., 2011), } \\
\text { (ChEBI, 2019). }\end{array}$ & 4-Terepenol & $\begin{array}{l}\text { 4-Terepenolis a tertiary alcohol found in tulsi. It is use in } \\
\text { tea and is an extract of tree oil. It shows significant } \\
\text { antimicrobial activities against bacteria, fungi, and yeast. }\end{array}$ \\
\hline $\begin{array}{l}\text { (Kashyap et al., 2011), } \\
\text { (Research Gate, 2018). }\end{array}$ & Myrtenol & $\begin{array}{l}\text { Myrtenol is an active compound in tulsi and it possesses } \\
\text { many activities such as: antibacterial and antibiofilm } \\
\text { activity. }\end{array}$ \\
\hline $\begin{array}{l}\text { (Kashyap et al., 2011), } \\
\text { (American Chemical } \\
\text { Society, 2017), } \\
\text { (Gruyter, 2018). }\end{array}$ & $\alpha$-Terpineol & $\begin{array}{l}\alpha \text {-Terpineol is a terpene alcohol that is found in natural } \\
\text { oils. It serves many applications such as: antioxidant, } \\
\text { anticancer, anticonvulsant, antiulcer, antihypertensive, } \\
\text { anti-nociceptive compound. It is also use by many to } \\
\text { enhance skin penetration, and also has insecticidal } \\
\text { properties. }\end{array}$ \\
\hline $\begin{array}{l}\text { (Kashyap et al., 2011), } \\
\text { (Research Gate, 2011). }\end{array}$ & Endo-Borneol & $\begin{array}{l}\text { Endo-Borneol is an active compound in tulsi and it } \\
\text { possesses many activities such as: anti-inflammatory and } \\
\text { antibacterial properties. }\end{array}$ \\
\hline $\begin{array}{l}\text { (Kashyap et al., 2011), } \\
\text { (Science Direct, 2021). }\end{array}$ & Saponins & $\begin{array}{l}\text { Saponins is a class of plant glycosides whereby water- } \\
\text { soluble sugars are attached to a lipophilic steroid or } \\
\text { triterpenoid. It possesses antiviral activities, anti- } \\
\text { inflammatory, anti-rheumatic responses. It is also useful in } \\
\text { treatment of syphilitic sores, earache boils, nose trouble, } \\
\text { wound healing, stomatitis and bad gum. }\end{array}$ \\
\hline
\end{tabular}




\begin{tabular}{|c|c|c|}
\hline $\begin{array}{l}\text { (Kashyap et al., 2011), } \\
\text { (Science Direct, 2021). }\end{array}$ & Triterpenoids & $\begin{array}{l}\text { Triterpenoids are compounds composed of a carbon } \\
\text { skeleton based on six isoprene units which are usually } \\
\text { derived biosynthetically from squalene. The biological } \\
\text { activities of triterpenoids include: anti-inflammatory, } \\
\text { antimycotic, anticarcinogenic, antidiabetic, } \\
\text { hepatoprotective, antimicrobial, analgesic, } \\
\text { immunomodulatory and cardiotonic responses. }\end{array}$ \\
\hline $\begin{array}{l}\text { (Kashyap et al., 2011), } \\
\text { (Yamani et al., 2016), } \\
\text { (Han et al., 2019), } \\
\text { (Science Direct, 2021). }\end{array}$ & Limonene & $\begin{array}{l}\text { Limonene is a compound found in oils obtained from } \\
\text { many citrus and herbal plant and is use for many aromatic } \\
\text { purposes. It is also useful as a food preservation, and it } \\
\text { inhibits gram-negative and gram-positive bacteria as well } \\
\text { as fungal activity. }\end{array}$ \\
\hline $\begin{array}{l}\text { (Kashyap et al., 2011), } \\
\text { (Koziol et al., 2014). }\end{array}$ & Monot & $\begin{array}{l}\text { Monoterpenes are found in the essential oils of many } \\
\text { plants including fruits, vegetables, and herbs. It works } \\
\text { well because of its antifungal, antibacterial, antioxidant, } \\
\text { anticancer, antiarrhythmic, anti-aggregating, local } \\
\text { anesthetic, antinociceptive, anti-inflammatory, } \\
\text { antihistaminic and anti-spasmodic responses. }\end{array}$ \\
\hline $\begin{array}{l}\text { (Kashyap et al., 2011); } \\
\text { (Yamani et al., 2016). }\end{array}$ & (E)-Ocimene & $\begin{array}{l}\text { E-Ocimene is a common monoterpene in nature. It is use } \\
\text { for its antimicrobial activity. }\end{array}$ \\
\hline $\begin{array}{c}\text { (Vyas, 2012), } \\
\text { (Science Direct, 2021). }\end{array}$ & Thymol & $\begin{array}{l}\text { Thymol is a compound found in essential oils. It possesses } \\
\text { many activities such as: antioxidant, antiseptic, anti- } \\
\text { inflammatory, anesthetic, antinociceptive, cicatrizing and } \\
\text { especially antibacterial and antifungal properties. }\end{array}$ \\
\hline $\begin{array}{c}\text { (Ivanescu et al., 2015). } \\
\text { (Borah \& Biswas, 2018). }\end{array}$ & Lactone & $\begin{array}{l}\text { Lactones is an ester whereby the functional group of the } \\
\text { ester became part of a ring structure with carbon atoms. It } \\
\text { acts as an acceptor and reacts with nucleophiles } \\
\text { (sulfhydryl or amino groups) found in enzymes, as a } \\
\text { transcription factor, and other proteins, alkylating them } \\
\text { irreversibly. }\end{array}$ \\
\hline $\begin{array}{l}\text { (Borah \& Biswas, 2018), } \\
\text { (Research Gate, 2019), } \\
\text { (Science Direct, 2021). }\end{array}$ & Anthraquinone & $\begin{array}{l}\text { Anthraquinones are aromatic organic compounds. It is } \\
\text { also referred to as anthracenedione or dioxoanthracene. It } \\
\text { exhibits many biological activities including: anti- } \\
\text { inflammatory, antiviral, antimicrobial, and anticancer } \\
\text { effects. }\end{array}$ \\
\hline (Yamani et al., 2016). & Methyl Isovalerate & Methyl Isovalerate is an ester compound found it tulsi and \\
\hline
\end{tabular}




\begin{tabular}{|c|c|c|}
\hline & & it possesses strong antimicrobial activity. \\
\hline (Yamani et al., 2016). & Ethyl Isovalerate & $\begin{array}{l}\text { Ethyl Isovalerate is an organic ester found it tulsi and it } \\
\text { possesses antimicrobial activity. }\end{array}$ \\
\hline $\begin{array}{l}\text { (Yamani et al., 2016), } \\
\text { (Med Broadcast, 2021). }\end{array}$ & Tricyclene & $\begin{array}{l}\text { Tricyclene is a tricyclic monoterpene found it tulsi and it } \\
\text { contributes to the plant's antibacterial activity. }\end{array}$ \\
\hline $\begin{array}{l}\text { (Kele \& Tepe, 2008), } \\
\text { (Yamani et al., 2016). }\end{array}$ & $\alpha$-Thujene & $\begin{array}{l}\alpha \text {-Thujene is a natural organic compound considered to be } \\
\text { a monoterpene. It is found in the essential oil extracts of a } \\
\text { variety of plants like tulsi. It possesses antioxidant, } \\
\text { antimicrobial and anti-inflammatory responses. }\end{array}$ \\
\hline (Yamani et al., 2016). & $\begin{array}{l}\text { Alpha Pinene } \\
\text { ( } \alpha \text {-Pinene) }\end{array}$ & $\begin{array}{l}\alpha \text {-Pinene is an active compound in tulsi and it possesses } \\
\text { antimicrobial activity. }\end{array}$ \\
\hline $\begin{array}{l}\text { (Yamani et al., 2016), } \\
\text { (Leafy, 2021). }\end{array}$ & Sabinene & $\begin{array}{l}\text { Sabinene is a bicyclic monoterpene with spicy, citrus, and } \\
\text { pine flavor and the aroma manifests that of cannabis. It is } \\
\text { utilized for its strong antibacterial activity. }\end{array}$ \\
\hline (Yamani et al., 2016). & $\begin{array}{l}\text { Beta Pinene } \\
\text { ( } \beta \text {-Pinene) }\end{array}$ & $\begin{array}{l}\beta \text {-Pinene is an active compound in tulsi and it possesses } \\
\text { strong antimicrobial activity. }\end{array}$ \\
\hline $\begin{array}{l}\text { (Yamani et al., 2016), } \\
\text { (Xiong et al., 2017). }\end{array}$ & 1-Octen-3-ol & $\begin{array}{l}\text { 1-Octen-3-ol is an active compound in tulsi and it } \\
\text { possesses many activities such as: strong antibacterial } \\
\text { activity against tested bacteria e.g., gram-positive bacteria, } \\
\text { and it can also inhibit the fungal growth and spore } \\
\text { germination. }\end{array}$ \\
\hline $\begin{array}{l}\text { (Yamani et al., 2016), } \\
\text { (Pub Chem, 2021). }\end{array}$ & Myrene & $\begin{array}{l}\text { Myrcene is a monoterpene and plays a role as a plant } \\
\text { metabolite, anti-inflammatory agent, antimicrobial agent, } \\
\text { an anabolic agent, a fragrance, a flavoring agent and a } \\
\text { volatile oil component. }\end{array}$ \\
\hline $\begin{array}{l}\text { (Yamani et al., 2016), } \\
\text { (Trulieve, 2021). }\end{array}$ & $\alpha$-Phellandrene & $\begin{array}{l}\alpha \text {-Phellandrene is a secondary terpene that is found in } \\
\text { several eucalyptus plant spp. It possesses anti- } \\
\text { inflammatory, antifungal, anticancer, analgesic and } \\
\text { antihyperalgesic and anti-depressive properties. }\end{array}$ \\
\hline $\begin{array}{l}\text { (Zaibet et al., 2015), } \\
\text { (Yamani et al., 2016). }\end{array}$ & Terpinene & $\begin{array}{l}\text { Terpinene is a terpene and an active compound in tulsi and } \\
\text { it possesses strong antimicrobial activity and acts as an } \\
\text { antioxidant. }\end{array}$ \\
\hline $\begin{array}{l}\text { (Yamani et al., 2016), } \\
\text { (Marchese et al., 2017). }\end{array}$ & p-Cymene & $\begin{array}{l}\text { p-Cymene is an aromatic, monoterpene and an active } \\
\text { compound in tulsi plant and it possesses antioxidant, } \\
\text { antinociceptive, anti-inflammatory, anxiolytic, anticancer } \\
\text { and antimicrobial effects. }\end{array}$ \\
\hline
\end{tabular}




\begin{tabular}{|c|c|c|}
\hline $\begin{array}{l}\text { (Yamani et al., 2016), } \\
\text { (Science Direct, 2021). }\end{array}$ & Eucalyptol & $\begin{array}{l}\text { Eucalyptol is an achiral, monoterpenoid aromatic } \\
\text { component of many plants. It possesses strong } \\
\text { antimicrobial and antioxidant activities. }\end{array}$ \\
\hline $\begin{array}{l}\text { (Yamani et al., 2016), } \\
\text { (Abstrax Tech, 2019). }\end{array}$ & Terpinolene & $\begin{array}{l}\text { Terpinolene is a cyclic monoterpene which is present in } \\
\text { small amounts in plants. It possesses antimicrobial, } \\
\text { anticancer and antioxidant properties. }\end{array}$ \\
\hline (Yamani et al., 2016). & Sabinene Hydrate & $\begin{array}{l}\text { Sabinene Hydrate is an active compound in tulsi and it } \\
\text { contributes to the plant's antibacterial property. }\end{array}$ \\
\hline (Yamani et al., 2016). & $\begin{array}{c}\text { Trans-Sabinene } \\
\text { Hydrate }\end{array}$ & $\begin{array}{l}\text { Trans-Sabinene Hydrate is an active compound in tulsi } \\
\text { and it contributes to the plant's strong antibacterial } \\
\text { property. }\end{array}$ \\
\hline (Yamani et al., 2016). & Carene & $\begin{array}{l}\text { Carene is an active compound in tulsi and it possesses } \\
\text { antimicrobial property. }\end{array}$ \\
\hline $\begin{array}{l}\text { (Yamani et al., 2016), } \\
\text { (Singh } \text { et al., 2020). }\end{array}$ & Fenchone & $\begin{array}{l}\text { Fenchone is a natural, organic, carboxylic compound } \\
\text { found in tulsi which demonstrates strong antioxidant, } \\
\text { antimicrobial and antifungal properties. }\end{array}$ \\
\hline $\begin{array}{l}\text { (International Scholarly } \\
\text { Research Notices, 2013), } \\
\text { (Yamani et al., 2016). }\end{array}$ & $\begin{array}{l}\text { Camphene-Hydric } \\
\text { Acid } \\
\text { (Camphene } \\
\text { Hydrate) }\end{array}$ & $\begin{array}{l}\text { Camphene-Hydric Acid is also known as Camphene } \\
\text { Hydrate. It is a bicyclic monoterpenoid compound. It } \\
\text { possesses antinociceptive activity. }\end{array}$ \\
\hline (Yamani et al., 2016). & $\begin{array}{l}\text { Delta-Terpineol } \\
(\delta \text {-Terpineol })\end{array}$ & $\begin{array}{l}\delta \text {-Terpineol is an active compound found in tulsi plants } \\
\text { and it possesses antimicrobial properties. }\end{array}$ \\
\hline $\begin{array}{l}\text { (Science Direct, 2003), } \\
\text { (Yamani et al., 2016). }\end{array}$ & Isoborneol & $\begin{array}{l}\text { Isoborenol is a major constituent of various plant parts, } \\
\text { tissues, and essential oils of the tulsi plant. It possesses } \\
\text { antimicrobial and antiviral activities and it is a potent } \\
\text { inhibitor of herpes simplex virus. }\end{array}$ \\
\hline $\begin{array}{l}\text { (Yamani et al., 2016), } \\
\text { (Encyclopedia Britannica, } \\
\text { 2021). }\end{array}$ & Borneol & $\begin{array}{l}\text { Borneol is an active monoterpene compound found in tulsi } \\
\text { plants and it possesses strong antimicrobial activities. }\end{array}$ \\
\hline $\begin{array}{l}\text { (Shapira et al., 2016), } \\
\text { (Yamani et al., 2016). }\end{array}$ & Terpinen-4-ol & $\begin{array}{l}\text { Terpinen-4-ol is a major component of essential oil } \\
\text { derived from several aromatic plants. It is a potent } \\
\text { bactericidal agent that possesses antifungal properties. }\end{array}$ \\
\hline $\begin{array}{l}\text { (Yamani et al., 2016), } \\
\text { (Science Direct, 2021). }\end{array}$ & Estragole & $\begin{array}{l}\text { Estragole is a natural constituent compound of basil oil. It } \\
\text { possesses antimicrobial and antifungal activity. }\end{array}$ \\
\hline $\begin{array}{l}\text { (Turkez et al., 2014). } \\
\text { (Yamani et al., 2016). }\end{array}$ & Copaene & $\begin{array}{l}\text { Copaene is a natural constituent compound of basil oil. It } \\
\text { possesses antimicrobial, antifungal and antioxidant }\end{array}$ \\
\hline
\end{tabular}




\begin{tabular}{|c|c|c|}
\hline & & activity. \\
\hline $\begin{array}{l}\text { (Yamani et al., 2016), } \\
\text { (Science Direct, 2021). }\end{array}$ & Zingiberene & $\begin{array}{l}\text { Zingiberene is an abundant molecule present in the oil of } \\
\text { tulsi. It is an herbal supplement and it possesses strong } \\
\text { antimicrobial activity. }\end{array}$ \\
\hline $\begin{array}{l}\text { (Yamani et al., 2016), } \\
\text { (Noriega et al., 2019). }\end{array}$ & Bourbonene & $\begin{array}{l}\text { Bourbonene is an active compound present in tulsi plants } \\
\text { and it possesses antimicrobial, anticancer and also } \\
\text { antioxidant properties. }\end{array}$ \\
\hline $\begin{array}{l}\text { (Science Direct, 2013), } \\
\text { (Yamani et al., 2016). }\end{array}$ & Guaiene & $\begin{array}{l}\text { Guaiene is an active compound present in tulsi plants and } \\
\text { it possesses antimicrobial, anticancer and also antioxidant } \\
\text { properties. }\end{array}$ \\
\hline $\begin{array}{l}\text { (Science Direct, 2015), } \\
\text { (Yamani et al., 2016). }\end{array}$ & Bergamotene & $\begin{array}{l}\text { Bergamotene is an active metabolite present in tulsi plants } \\
\text { and it possesses antimicrobial, anticancer, mutagenic and } \\
\text { also antioxidant properties }\end{array}$ \\
\hline $\begin{array}{l}\text { (Yamani et al., 2016), } \\
\text { (Mancianti, 2019) }\end{array}$ & Sesquiphellandrene & $\begin{array}{l}\text { Sesquiphellandrene is an active compound present in tulsi } \\
\text { plants and it possesses antimicrobial and also antioxidant } \\
\text { properties. }\end{array}$ \\
\hline $\begin{array}{l}\text { (Yamani et al., 2016), } \\
\text { (Borah \& Biswas, 2018). }\end{array}$ & Farnesene & $\begin{array}{l}\text { Farnesene is an active compound present in tulsi plants } \\
\text { and it possesses acaricide, allergenic, analgesic, } \\
\text { anesthetic, antibacterial, anti-inflammatory, antiedemic, } \\
\text { antioxidant, antiviral, antitumor and antiulcer conditions. }\end{array}$ \\
\hline (Yamani et al., 2016). & Sesquisabinene & $\begin{array}{l}\text { Sesquisabinene hydrate is a sesquiterpenoid that is } \\
\text { bicyclic. It possesses antibacterial activity. }\end{array}$ \\
\hline $\begin{array}{l}\text { (Yamani et al., 2016), } \\
\text { (Ali et al., 2017). }\end{array}$ & $\begin{array}{l}\text { Humulene } \\
\text { ( } \alpha \text {-humulene or } \alpha \text { - } \\
\text { caryophyllene) }\end{array}$ & $\begin{array}{l}\alpha \text {-humulene or } \alpha \text {-caryophyllene, is a naturally occurring } \\
\text { monocyclic sesquiterpene. It possesses antimicrobial, } \\
\text { antioxidant, cytotoxic and anti-inflammatory activities. }\end{array}$ \\
\hline (Yamani et al., 2016). & Bicyclogermacrene & $\begin{array}{l}\text { Bicyclogermacrene is a sesquiterpene derived from } \\
\text { germacrene. It is an active compound present in tulsi } \\
\text { plants and it possesses strong antimicrobial properties. }\end{array}$ \\
\hline (Yamani et al., 2016). & Germacrene & $\begin{array}{l}\text { Germacrenes are a class of volatile organic sesquiterpenes. } \\
\text { It is an active compound present in tulsi plants and it } \\
\text { possess strong antibacterial property. }\end{array}$ \\
\hline (Yamani et al., 2016). & Longipinene & $\begin{array}{l}\text { Longipinene is an active compound present in tulsi plants } \\
\text { and it possesses antibacterial property. }\end{array}$ \\
\hline (Yamani et al., 2016). & Bisabolene-Z & $\begin{array}{l}\text { Bisabolene- } \mathrm{Z} \text { is an active compound present in tulsi plants } \\
\text { and it possesses antimicrobial and antioxidant properties. }\end{array}$ \\
\hline (Silva et al., 2009), & Muurolene & Muurolene belongs to the class of organic compounds \\
\hline
\end{tabular}




\begin{tabular}{|c|c|c|}
\hline (Yamani et al., 2016). & & $\begin{array}{l}\text { known as sesquiterpenoids an active compound present in } \\
\text { tulsi plants. It possesses antimicrobial and antioxidant } \\
\text { properties. }\end{array}$ \\
\hline $\begin{array}{l}\text { (Yamani et al., 2016), } \\
\text { (FoodB, 2021), } \\
\text { (TGSC Information } \\
\text { System, 2021). }\end{array}$ & $\begin{array}{l}\text { Beta Bisabolene } \\
\text { ( } \beta \text {-Bisabolene) }\end{array}$ & $\begin{array}{l}\text { The } \beta \text {-Bisabolene is a compound belonging to the group } \\
\text { sesquiterpenes which is found in the fragrances. It } \\
\text { possesses antimicrobial and antioxidant properties. }\end{array}$ \\
\hline (Yamani et al., 2016). & Cadinene & $\begin{array}{l}\text { Cadinene is one of the most widely occurring plant } \\
\text { sesquiterpenes. It possesses antimicrobial and antioxidant } \\
\text { properties. }\end{array}$ \\
\hline $\begin{array}{l}\text { (Yamani et al., 2016), } \\
\text { (Chem Spider, 2021). }\end{array}$ & $\begin{array}{c}\text { Alpha Bisabolene } \\
\text { ( } \alpha \text {-Bisabolene) }\end{array}$ & $\begin{array}{l}\text { The } \alpha \text {-Bisabolene is a compound belonging to the group } \\
\text { sesquiterpenes which is found in the fragrances. It } \\
\text { possesses antimicrobial and antioxidant properties. }\end{array}$ \\
\hline $\begin{array}{l}\text { (Naidoo et al., 2008), } \\
\text { (Yamani et al., 2016). }\end{array}$ & Cubebene & $\begin{array}{l}\text { Cubebene is a tricyclic sesquiterpene and an important } \\
\text { extract of tulsi oil extract. It possesses strong } \\
\text { antimicrobial, antioxidant and anti-inflammatory } \\
\text { responses. }\end{array}$ \\
\hline $\begin{array}{l}\text { (Science Direct, 2013), } \\
\text { (Yamani et al., 2016). }\end{array}$ & Amorphene & $\begin{array}{l}\text { Amorphene is an active compound present in tulsi plants } \\
\text { and it possesses antimicrobial, anticancer, antioxidant and } \\
\text { anti-inflammatory properties. }\end{array}$ \\
\hline (Borah \& Biswas, 2018). & $\begin{array}{l}\text { Benzene; } 1,2- \\
\text { dimethoxy-4-(1- } \\
\text { propenyl) }\end{array}$ & $\begin{array}{l}\text { Benzene; 1, 2-dimethoxy-4-(1-propenyl) is an active } \\
\text { compound in tulsi and it possesses many activities such } \\
\text { as: it is useful as an insect attractant and utilized in } \\
\text { perfumery and to create flavor antibacterial. It also acts as } \\
\text { nematicides. }\end{array}$ \\
\hline (Borah \& Biswas, 2018). & $\begin{array}{c}\text { Cyclohexane; 1, 2, } \\
\text { 4-triethenyl }\end{array}$ & $\begin{array}{l}\text { Cyclohexane; 1, 2, 4-triethenyl is an active compound in } \\
\text { tulsi and it possesses many activities such as: } \\
\text { antibacterial, anti-Inflammatory, antiedemic and } \\
\text { antispasmodic qualities. }\end{array}$ \\
\hline
\end{tabular}

Table Six (6) showing the Phytochemical Composition of Cymbopogon citratus.

\begin{tabular}{|c|c|c|}
\hline Author(s) & $\begin{array}{c}\text { Phytochemicals } \\
\text { (Active } \\
\text { Constituents) }\end{array}$ & Description of Phytochemicals/ Biological Activities \\
\hline $\begin{array}{c}\text { (Shigeharu } \text { et al., 2001), } \\
\text { (Costa } \text { et al., 2006), }\end{array}$ & $\begin{array}{c}\text { 6-Methylhept-5-en- } \\
\text { 2-one }\end{array}$ & $\begin{array}{c}\text { 6-Methylhept-5-en-2-one is also known as Sulcatone. It } \\
\text { is a heptenone a volatile oil component of lemon grass. It }\end{array}$ \\
\hline
\end{tabular}




\begin{tabular}{|c|c|c|}
\hline $\begin{array}{l}\text { (Brugger et al., 2019), } \\
\text { (Hartatie e. al., 2019), } \\
\text { (Pub Chem, 2021). }\end{array}$ & (Sulcatone) & $\begin{array}{l}\text { plays a role as a pheromone, a plant metabolite and } \\
\text { possesses strong antidiabetic activity. }\end{array}$ \\
\hline $\begin{array}{l}\text { (Brugger et al., 2019), } \\
\text { (American Chemical } \\
\text { Society, 2021). }\end{array}$ & Camphene & $\begin{array}{l}\text { Camphene is a monoterpene with a bicyclic skeleton that } \\
\text { occurs in one or both of its enantiomeric forms in a } \\
\text { variety of essential oils. It possesses antioxidant and } \\
\text { antimicrobial activities. }\end{array}$ \\
\hline $\begin{array}{l}\text { (Farangh } \text { et al., 2013), } \\
\text { (Bidinotto et al., 2011), } \\
\text { (Nanon } \text { et al., 2014), } \\
\text { (Brugger } \text { et al., 2019), } \\
\text { (Han et al., 2019), } \\
\text { (Science Direct, 2021). }\end{array}$ & Limonene & $\begin{array}{l}\text { Limonene is a compound found in oils obtained from } \\
\text { many citrus and herbal plant and is used for many } \\
\text { aromatic purposes. It is use as a food preservation and it } \\
\text { inhibits gram-negative and gram-positive bacteria as well } \\
\text { as fungal activity. It also possesses strong antioxidant } \\
\text { activity. }\end{array}$ \\
\hline $\begin{array}{l}\text { (Yagi et al., 2016), } \\
\text { (Brugger et al., 2019). }\end{array}$ & Nonan-4-ol & $\begin{array}{l}\text { Nonan-4-ol is an active compound in lemon grass and it } \\
\text { possesses many activities such as: antiproliferative, } \\
\text { antioxidant and antibacterial properties. }\end{array}$ \\
\hline $\begin{array}{c}\text { (Soares et al., 2013), } \\
\text { (Brugger et al., 2019), } \\
\text { (Hartatie et al., 2019), } \\
\text { (Wilson, 2019), } \\
\text { (Science Direct, 2021). }\end{array}$ & Citronella & $\begin{array}{l}\text { Citronella oil is an essential oil that is obtained from } \\
\text { lemon grass. It possesses many activities such as: } \\
\text { antibiofilm, insecticidal and antibacterial properties. }\end{array}$ \\
\hline $\begin{array}{l}\text { (Berenice } \text { et al., 1991), } \\
\text { (Dharmendra } \text { et al., } \\
\text { 2001), } \\
\text { (Rhanita } \text { et al., 2014), } \\
\text { (Brugger et al., 2019), } \\
\text { (De Lira } \text { et al., 2020), } \\
\text { (EWG's Skin Deep, } \\
\text { 2021). }\end{array}$ & Citronellol & $\begin{array}{l}\text { Citronellol is a naturally occurring scent ingredient } \\
\text { derived from plants. It possesses antifungal activity, } \\
\text { display higher inhibitory and bactericidal activity against } \\
\text { pathogens. }\end{array}$ \\
\hline $\begin{array}{l}\text { (Scielo, 2009), } \\
\text { (Brugger et al., 2019), } \\
\text { (Word Nik, 2021). }\end{array}$ & Neral & $\begin{array}{l}\text { Neral is an oily liquid aldehyde found in lemon grass and } \\
\text { it possesses strong antimicrobial, antifungal and anti- } \\
\text { inflammatory responses. }\end{array}$ \\
\hline $\begin{array}{l}\text { (Brugger et al., 2019), } \\
\quad \text { (Abstrax, 2021). }\end{array}$ & Geraniol & $\begin{array}{l}\text { Geraniol is an acyclic monoterpene alcohol found within } \\
\text { essential oil of lemon grass. It possesses strong } \\
\text { antibacterial activity. }\end{array}$ \\
\hline
\end{tabular}




\begin{tabular}{|c|c|c|}
\hline $\begin{array}{l}\text { (Grace } \text { et al., 1984), } \\
\text { Viana } \text { et al., 2000), } \\
\text { (Mirghani et al., 2012), } \\
\text { (Bhartie } \text { et al., 2013), } \\
\text { (Kumar et al., 2013). } \\
\text { (Rhanita } \text { et al., 2014), } \\
\text { (Shi et al., 2016), } \\
\text { (Brugger } \text { et al., 2019), } \\
\text { (Hartatie } \text { et al., 2019), } \\
\text { (Pub Chem, 2021). }\end{array}$ & $\begin{array}{c}\text { Citral } \\
\text { (Geranial) }\end{array}$ & $\begin{array}{l}\text { Citral is a naturally occurring aliphatic aldehyde of the } \\
\text { terpene series and it is an isomeric mixture of geranial } \\
\text { and neral. Citral is reported to possess antimicrobial } \\
\text { activity against certain pathogenic and food-spoilage } \\
\text { bacteria. }\end{array}$ \\
\hline $\begin{array}{l}\text { (Soares et al., 2013), } \\
\text { (Brugger et al., 2019), } \\
\text { (Hartatie et al., 2019), } \\
\quad \text { (ChEBI, 2021). }\end{array}$ & Geranyl Acetate & $\begin{array}{l}\text { Geranyl Acetate is a monoterpenoid that is the acetate } \\
\text { ester derivative of geraniol. It plays a role as a plant } \\
\text { metabolite and is known for its antinociceptive activity. }\end{array}$ \\
\hline $\begin{array}{l}\text { (Dahham et al., 2015), } \\
\text { (Brugger et al., 2019), } \\
\text { (Science Direct, 2021). }\end{array}$ & $\begin{array}{c}\text { Beta Caryophyllene } \\
\text { ( } \beta \text {-Caryophyllene) }\end{array}$ & $\begin{array}{l}\text { Beta Caryophyllene is a natural bicyclic sesquiterpene } \\
\text { that is a constituent of many essential oils. It } \\
\text { demonstrates selective antibacterial activity, anti-fungal } \\
\text { activity and strong antioxidant effects. }\end{array}$ \\
\hline $\begin{array}{c}\text { (Silva } \text { et al., 2009), } \\
\text { (Brugger et al., 2019). }\end{array}$ & Muurolene & $\begin{array}{l}\text { Muurolene belongs to the class of organic compounds } \\
\text { known as sesquiterpenoids an active compound present } \\
\text { in lemon grass. It possesses strong antimicrobial and } \\
\text { antioxidant properties. }\end{array}$ \\
\hline $\begin{array}{c}\text { (Brugger } \text { et al., 2019), } \\
\text { (Pub Chem, 2021). }\end{array}$ & $\begin{array}{c}\text { Caryophyllene } \\
\text { Oxide }\end{array}$ & $\begin{array}{l}\text { Caryophyllene oxide is a bicyclic sesquiterpene and a } \\
\text { metabolite of } \beta \text {-Caryophyllene. It possesses many } \\
\text { important properties such as: antimicrobial, } \\
\text { antioxidative, anticarcinogenic, anti-inflammatory, and } \\
\text { even analgesic activities. }\end{array}$ \\
\hline $\begin{array}{l}\text { (Kamatou \& Viljoen, } \\
\text { 2008), } \\
\text { (Hartatie et al., 2019), } \\
\text { (Science Direct, 2017). }\end{array}$ & Linalool & $\begin{array}{l}\text { Linalool is a noncyclic monoterpenoid that is commonly } \\
\text { extracted from lemon grass. It is a colorless liquid with a } \\
\text { spicy herbal odor. It possesses antimicrobial, anticancer. } \\
\text { anti-inflammatory, antioxidant properties and it have } \\
\text { various effects on the central nervous system. }\end{array}$ \\
\hline $\begin{array}{l}\text { Grace } \text { et al., 1984), } \\
\text { (Rhanita et al., 2014), } \\
\text { (Hartatie et al., 2019), } \\
\text { (Brugnatelli, 2021). }\end{array}$ & $\begin{array}{l}\text { Beta Myrcene } \\
\text { ( } \beta \text {-Myrcene) }\end{array}$ & $\begin{array}{l}\beta \text {-myrcene is an acyclic monoterpene commonly found in } \\
\text { nature (along with other terpenes) in the essential oil of } \\
\text { lemongrass. It possesses antibacterial, anti-Gout and anti- } \\
\text { inflammatory activity. }\end{array}$ \\
\hline
\end{tabular}




\begin{tabular}{|c|c|c|}
\hline (Hartatie et al., 2019). & Longipinenepoxide & $\begin{array}{l}\text { Longipinenepoxide is a biologically active compound } \\
\text { found in lemon grass and it possesses antibacterial } \\
\text { property. }\end{array}$ \\
\hline $\begin{array}{l}\text { (Hartatie et al., 2019), } \\
\text { (Pub Chem, 2021). }\end{array}$ & Patchouli Alcohol & $\begin{array}{l}\text { Patchouli alcohol is a carbo-tricyclic compound and a } \\
\text { sesquiterpenoid tertiary alcohol. It possesses strong } \\
\text { antibacterial property. }\end{array}$ \\
\hline $\begin{array}{l}\text { (Hartatie et al., 2019), } \\
\text { (Encyclopedia } \\
\text { Britannica, 2021). }\end{array}$ & $\begin{array}{l}\text { Phthalic Acid } \\
\qquad(1,2- \\
\text { Benzenedicarboxylic } \\
\text { Acid) }\end{array}$ & $\begin{array}{l}\text { Phthalic acid is a colorless, crystalline aromatic } \\
\text { dicarboxylic acid compound. It possesses strong } \\
\text { antioxidant property. }\end{array}$ \\
\hline $\begin{array}{l}\text { (Habib \& Karim, 2009), } \\
\text { (Hartatie et al., 2019). }\end{array}$ & Diotyl Ester & $\begin{array}{l}\text { Diotyl Ester is a biologically active compound found in } \\
\text { lemon grass and it possesses antimicrobial and cytotoxic } \\
\text { activities. }\end{array}$ \\
\hline $\begin{array}{l}\text { (Da Silva et al., 2016), } \\
\text { (Hartatie et al., 2019). }\end{array}$ & Junip & $\begin{array}{l}\text { Juniper Camphor is an organic terpene compound that is } \\
\text { commonly used in in many products making. It possesses } \\
\text { antiviral, antimicrobial, antitussive, and analgesic } \\
\text { properties. }\end{array}$ \\
\hline $\begin{array}{l}\text { (Habib \& Karim, 2009), } \\
\text { (Hartatie et al., 2019). }\end{array}$ & $\begin{array}{l}\text { Dioctyl Phthalate } \\
\text { [Bis (2-ethylhexyl) } \\
\text { Phthalate] }\end{array}$ & $\begin{array}{l}\text { Dioctyl Phthalate is a biologically active compound } \\
\text { found in lemon grass and it possesses antimicrobial and } \\
\text { cytotoxic activities. }\end{array}$ \\
\hline $\begin{array}{l}\text { (Kumar \& Pandey, } \\
\text { 2013), } \\
\text { (Opeyemi et al., 2015). }\end{array}$ & iid & $\begin{array}{l}\text { Flavonoids are polyphenols on the basis flavin. They are } \\
\text { known as antioxidant and radical scavengers. It possesses } \\
\text { antibacterial and antifungal properties. }\end{array}$ \\
\hline $\begin{array}{l}\text { (Desai \& Parik, 2012), } \\
\text { (Science Direct, 2016). }\end{array}$ & Quercetin & $\begin{array}{l}\text { Quercetin is a natural flavonoid that is abundantly found } \\
\text { in vegetables and fruits. It is a pigment that belongs to the } \\
\text { group flavonoids. It is very active against various } \\
\text { pathogens. It also possesses antibacterial and antifungal } \\
\text { properties. It is useful for the treatment of leprosy, eye } \\
\text { problem, epitaxies, intestinal worms, anorexia, } \\
\text { biliousness and skin ulcers }\end{array}$ \\
\hline $\begin{array}{l}\text { (Noor et al., 2012), } \\
\text { (Chen \& Chen, 2013). }\end{array}$ & Kaempferol & $\begin{array}{l}\text { Kaempferol is a polyphenol antioxidant found in lemon } \\
\text { grass. It also possesses Anti-inflammatory response. It is } \\
\text { useful in the treatment of leprosy, eye problem, epitaxies, } \\
\text { intestinal worms, anorexia, biliousness and skin ulcers. }\end{array}$ \\
\hline $\begin{array}{l}\text { (Bagheri et al., 2007), } \\
\text { (Science Direct, 2018). }\end{array}$ & Apigenin & $\begin{array}{l}\text { Apigenin is a natural flavonoid that is abundantly present } \\
\text { in plants. It has various effects such as: antioxidant, }\end{array}$ \\
\hline
\end{tabular}




\begin{tabular}{|c|c|c|}
\hline & & chemoprevention and anti-inflammatory. \\
\hline $\begin{array}{l}\text { (Govere et al., 2000), } \\
\text { (The Free Dictionary, } \\
\text { 2021). }\end{array}$ & Elemicin & $\begin{array}{l}\text { Elemicin is a natural, aromatic, organic phenylpropene } \\
\text { compound found in lemon grass. It possesses } \\
\text { antibacterial and anti-inflammatory responses. }\end{array}$ \\
\hline $\begin{array}{c}\text { (Mahboubi \& } \\
\text { Kazempour, 2012), } \\
\text { (Libre Text, 2019). }\end{array}$ & Catechol & $\begin{array}{l}\text { Catechol also known as pyrocatechol, and it is a toxic, } \\
\text { organic, phenolic compound. It is very beneficial for its } \\
\text { antioxidant and antimicrobial responses. }\end{array}$ \\
\hline $\begin{array}{l}\text { (Abbas \& Hassan, 2003), } \\
\text { (Biomedicine \& } \\
\text { Pharmacotherapy, 2018). }\end{array}$ & Chlorogenic Acid & $\begin{array}{l}\text { Chlorogenic acid is a dietary, phenolic compound and the } \\
\text { ester of caffeic acid. It plays several important and } \\
\text { therapeutic roles such as: antioxidant, antibacterial, } \\
\text { Hepatoprotective, antipyretic, cardioprotective, antiviral, } \\
\text { anti-obesity, neuroprotective, anti-inflammatory, } \\
\text { hypertension and antimicrobial responses. }\end{array}$ \\
\hline $\begin{array}{l}\text { (Kepe, 2004), } \\
\text { (Frontiers in Oncology, } \\
\text { 2019). }\end{array}$ & Caffeic Acid & $\begin{array}{l}\text { Caffeic acid is a phenolic compound that is synthesized } \\
\text { by all plant species. It promotes antioxidant, anti- } \\
\text { inflammatory and anticarcinogenic activities. }\end{array}$ \\
\hline (Leite et al., 2011). & Hydroquinone & $\begin{array}{l}\text { Hydroquinone is a biologically active compound found } \\
\text { in lemon grass and it possesses antimicrobial properties. }\end{array}$ \\
\hline $\begin{array}{l}\text { (López-Lázaro, 2009), } \\
\text { (Padalia et al., 2011). }\end{array}$ & Luteolin & $\begin{array}{l}\text { Luteolin is a naturally occurring flavonoid found in } \\
\text { lemon grass. It inhibits angiogenesis, to prevent } \\
\text { carcinogenesis, to reduce tumor growth in vivo and to } \\
\text { sensitize tumor cells. }\end{array}$ \\
\hline $\begin{array}{l}\text { (Shackleton et al., 2007), } \\
\text { (Pub Chem, 2021). }\end{array}$ & $\begin{array}{l}\text { Luteolin 7-O- } \\
\text { Glucoside } \\
\text { (Cynaroside) }\end{array}$ & $\begin{array}{l}\text { Luteolin 7-O-beta-D-Glucoside is a glycosyloxyflavone. } \\
\text { It has a role as an antioxidant and a plant metabolite. }\end{array}$ \\
\hline (Aibinu et al., 2007). & Isoscoparin & $\begin{array}{l}\text { Isoscoparin is a biologically active compound found in } \\
\text { lemon grass and it possesses antimicrobial properties. }\end{array}$ \\
\hline (Jeong et al., 2009). & $\begin{array}{l}\text { 2''-O-rahmnosyl } \\
\text { Isoorientin }\end{array}$ & $\begin{array}{l}\text { 2"'-O-rahmnosyl Isoorientin is a biologically active } \\
\text { compound found in lemon grass and it possesses strong } \\
\text { antimicrobial properties. }\end{array}$ \\
\hline $\begin{array}{l}\text { (Opeyemi et al., 2015), } \\
\text { (Libre Text, 2020), } \\
\text { (Wu et al., 2020). }\end{array}$ & Terpenoids & $\begin{array}{l}\text { Terpenoids are also called Isoprenoids and they are a } \\
\text { large and diverse group of lipids which are derived from } \\
\text { five-carbon isoprene units and are assembled in } \\
\text { thousands of different combinations. It possesses } \\
\text { immunomodulatory, anti-inflammatory, antimicrobial, } \\
\text { antioxidant, and anticancer activities. }\end{array}$ \\
\hline
\end{tabular}




\begin{tabular}{|c|c|c|}
\hline $\begin{array}{l}\text { (Opeyemi et al., 2015), } \\
\text { (Krebihel, 2018). }\end{array}$ & Tannins & $\begin{array}{l}\text { Tannins are a group of bitter and astringent compounds, } \\
\text { and they can be found abundantly in the wood, bark, } \\
\text { leaves and fruit of plants. It acts as potential metal ion } \\
\text { chelators, protein precipitating agents, and works as a } \\
\text { biological antioxidant. }\end{array}$ \\
\hline $\begin{array}{l}\text { (Moore-Nibel et al., } \\
\text { 2012), } \\
\text { (Rahim et al., 2013), } \\
\text { Paula et al., 2014). }\end{array}$ & $\begin{array}{c}\text { Isovaleranic } \\
\text { Aldehyde }\end{array}$ & $\begin{array}{l}\text { Isovaleranic Aldehyde is a biologically active compound } \\
\text { found in lemon grass and it possesses strong } \\
\text { antimicrobial properties. }\end{array}$ \\
\hline $\begin{array}{l}\text { (Moore-Nibel } \text { et al., } \\
\text { 2012), } \\
\text { (Rahim et al., 2013), } \\
\text { Paula et al., 2014). }\end{array}$ & Anthocyanin & $\begin{array}{l}\text { Anthocyanins are a type of flavonoid compound found in } \\
\text { lemon grass and it possesses both antimicrobial and } \\
\text { antioxidant properties. }\end{array}$ \\
\hline $\begin{array}{l}\text { (Moore-Nibel } \text { et al., } \\
\text { 2012), } \\
\text { (Rahim et al., 2013), } \\
\text { Paula et al., 2014). }\end{array}$ & Fumesols & $\begin{array}{l}\text { Fumesols is a biologically active compound found in } \\
\text { lemon grass and it possesses antimicrobial properties. }\end{array}$ \\
\hline $\begin{array}{l}\text { (Moore-Nibel } \text { et al., } \\
\text { 2012), } \\
\text { (Costa } \text { et al., 2013), } \\
\text { (Rahim } \text { et al., 2013), } \\
\text { (Vahid } \text { et al., 2013), } \\
\text { Paula } \text { et al., 2014). }\end{array}$ & Methylheptenone & $\begin{array}{l}\text { Methylheptenone is a biologically active compound } \\
\text { found in lemon grass and it possesses antimicrobial } \\
\text { properties. }\end{array}$ \\
\hline $\begin{array}{l}\text { (Moore-Nibel } \text { et al., } \\
\text { 2012), } \\
\text { (Rahim } \text { et al., 2013), } \\
\text { Paula et al., 2014). }\end{array}$ & Valeric Esters & $\begin{array}{l}\text { Valeric Ester is found naturally and it is a biologically } \\
\text { active compound found in lemon grass and it possesses } \\
\text { strong antimicrobial properties. }\end{array}$ \\
\hline $\begin{array}{l}\text { (Moore-Nibel } \text { et al., } \\
\text { 2012), } \\
\text { (Rahim et al., 2013), } \\
\text { Paula et al., 2014). }\end{array}$ & Furfural & $\begin{array}{l}\text { Furfural is a natural dehydration product of xylose and it } \\
\text { promotes strong antimicrobial activity. }\end{array}$ \\
\hline $\begin{array}{l}\text { (Moore-Nibel et al., } \\
\text { 2012). } \\
\text { (Rahim et al., 2013), } \\
\text { (Paula et al., 2014). }\end{array}$ & Isopulegol & $\begin{array}{l}\text { Isopulegol is an aromatic terpene compound present in } \\
\text { plants and it promotes the plant's strong antimicrobial } \\
\text { and antioxidant activities. }\end{array}$ \\
\hline (Moore-Nibel et al., & p-Coumaric Acid & p-Coumaric acid is a hydroxycinnamic acid. Its \\
\hline
\end{tabular}




\begin{tabular}{|c|c|c|}
\hline $\begin{array}{l}\text { 2012), } \\
\text { (Rahim et al., 2013), } \\
\text { (Paula et al., 2014), } \\
\text { (Pei et al., 2015). }\end{array}$ & & $\begin{array}{l}\text { biological activities include: antioxidant, anticancer, } \\
\text { antimicrobial, antiviral, anti-inflammatory, antiplatelet } \\
\text { aggregation, anxiolytic, antipyretic, analgesic, and anti- } \\
\text { arthritis activities. }\end{array}$ \\
\hline $\begin{array}{l}\text { (Celso et al., 2011), } \\
\text { (Rhanita et al., 2014). }\end{array}$ & Genariol & $\begin{array}{l}\text { Geraniol is an acyclic monoterpene alcohol present in } \\
\text { lemon grass. It contributes to the plant's antiviral, } \\
\text { antifungal and antibacterial activity. }\end{array}$ \\
\hline $\begin{array}{l}\text { (Rhanita et al., 2014), } \\
\text { (TGSC Information } \\
\text { System, 2021). }\end{array}$ & $\alpha$-Bisabolene & $\begin{array}{l}\text { The } \alpha \text {-Bisabolene is a compound belonging to the group } \\
\text { sesquiterpenes which is found in the fragrances. It } \\
\text { possesses antimicrobial and antioxidant properties. }\end{array}$ \\
\hline $\begin{array}{l}\text { (Costa } \text { et al., 2013), } \\
\text { Vahid } \text { et al., 2013). }\end{array}$ & Neointermediol & $\begin{array}{l}\text { Neointermediol is a biologically active compound found } \\
\text { in lemon grass and it possesses strong antimicrobial } \\
\text { properties. }\end{array}$ \\
\hline $\begin{array}{l}\text { (Costa } \text { et al., 2013), } \\
\text { Vahid et al., 2013). }\end{array}$ & Selina-6-en-4-ol & $\begin{array}{l}\text { Selina-6-en-4-ol is a biologically active compound found } \\
\text { in lemon grass and it possesses antimicrobial properties. }\end{array}$ \\
\hline $\begin{array}{l}\text { (Costa } \text { et al., 2013), } \\
\text { Vahid et al., 2013). }\end{array}$ & $\alpha$-Cadinol & $\begin{array}{l}\alpha \text {-Cadinol is a cadinane carbocyclic sesquiterpenoid and } \\
\text { it plays a role as a plant metabolite, a fungicide, an } \\
\text { antioxidant and a volatile oil component. }\end{array}$ \\
\hline $\begin{array}{l}\text { (Costa } \text { et al., 2013), } \\
\text { Vahid } \text { et al., 2013). }\end{array}$ & $\begin{array}{c}\text { Eudsema-7(11)-en- } \\
\text { 4-ol }\end{array}$ & $\begin{array}{l}\text { Eudsema-7(11)-en-4-ol is a biologically active } \\
\text { compound found in lemon grass and it possesses strong } \\
\text { antimicrobial properties. }\end{array}$ \\
\hline $\begin{array}{l}\text { (Costa } \text { et al., 2013), } \\
\text { Vahid } \text { et al., 2013). }\end{array}$ & $\begin{array}{l}\text { 3,7-dimethyl-1, 3, 6- } \\
\text { Octatriene }\end{array}$ & $\begin{array}{l}\text { 3,7-dimethyl-1, 3, 6-Octatriene is a biologically active } \\
\text { compound found in lemon grass and it contributes to the } \\
\text { plant's antimicrobial properties. }\end{array}$ \\
\hline $\begin{array}{l}\text { (Costa } \text { et al., 2013), } \\
\text { Vahid et al., 2013). }\end{array}$ & Decanal & $\begin{array}{l}\text { Decanal is a saturated fatty aldehyde and a biologically } \\
\text { active compound found in lemon grass and it is known } \\
\text { for its antimicrobial properties. }\end{array}$ \\
\hline $\begin{array}{l}\text { (Costa } \text { et al., 2013), } \\
\text { Vahid et al., 2013), } \\
\text { (Ibrahim \& Mohamed, } \\
\text { 2016). }\end{array}$ & Naphthalene & $\begin{array}{l}\text { Naphthalene is an aromatic hydrocarbon and a } \\
\text { biologically active compound found in lemon grass and it } \\
\text { possesses: antimicrobial, antioxidant, cytotoxic, Anti- } \\
\text { inflammatory, anti-protozoal, and anti-platelet } \\
\text { aggregation properties. }\end{array}$ \\
\hline (Halabi \& Sheikh, 2013), & Elemol & Elemol is a sesquiterpenoid that is isopropanol and the \\
\hline
\end{tabular}




\begin{tabular}{|c|c|c|}
\hline (Salem et al., 2016). & & $\begin{array}{l}\text { most abundant compound found in lemon grass oil } \\
\text { extract. It possesses antioxidant, antimicrobial, antitumor } \\
\text { and antiproliferative properties. }\end{array}$ \\
\hline $\begin{array}{l}\text { (Halabi \& Sheikh, 2013), } \\
\text { (Scientific Report, 2017). }\end{array}$ & $\beta$-Eudesmol & $\begin{array}{l}\beta \text {-Eudesmol is an oxygenated sesquiterpene contained in } \\
\text { medicinal and edible plants. It promotes strong } \\
\text { antimicrobial activity. }\end{array}$ \\
\hline (Halabi \& Sheikh, 2013). & Cubebol & $\begin{array}{l}\text { Cubebol is a natural sesquiterpene alcohol found in } \\
\text { lemon grass and it promotes antimicrobial activity. }\end{array}$ \\
\hline $\begin{array}{l}\text { (Halabi \& Sheikh, 2013), } \\
\text { (Ali et al., 2019). }\end{array}$ & $\begin{array}{l}\text { Humulene } \\
\text { ( } \alpha \text {-humulene or } \alpha- \\
\text { caryophyllene) }\end{array}$ & $\begin{array}{l}\alpha \text {-Humulene or } \alpha \text {-caryophyllene, is a naturally occurring } \\
\text { monocyclic sesquiterpene. It possesses antimicrobial, } \\
\text { antioxidant, cytotoxic and anti-inflammatory activities. }\end{array}$ \\
\hline (Soares et al., 2013). & Verbenone & $\begin{array}{l}\text { Verbenone is a natural organic terpene compound and it } \\
\text { possesses strong pesticidal activity. }\end{array}$ \\
\hline $\begin{array}{l}\text { (Soares et al., 2013), } \\
\quad \text { (Leafy, 2021). }\end{array}$ & Sabinene & $\begin{array}{l}\text { Sabinene is a bicyclic monoterpene with spicy, citrus, } \\
\text { and pine flavor and the aroma manifests that of cannabis. } \\
\text { It is utilized for its strong antibacterial activity. }\end{array}$ \\
\hline $\begin{array}{l}\text { (Farangh et al., 2013), } \\
\text { (Nanon et al., 2014). }\end{array}$ & Mentha-1 (7) & $\begin{array}{l}\text { Mentha-1 ( } 7) \text { is a biologically active compound found in } \\
\text { lemon grass and it possesses potent antimicrobial } \\
\text { properties. }\end{array}$ \\
\hline $\begin{array}{l}\text { (Farangh et al., 2013), } \\
\text { (Nanon et al., 2014). }\end{array}$ & 8-dien-2-ol cis & $\begin{array}{l}\text { 8-dien-2-ol cis is a biologically active compound found } \\
\text { in lemon grass and it possesses antimicrobial properties. }\end{array}$ \\
\hline $\begin{array}{l}\text { (Farangh et al., 2013), } \\
\text { (Nanon et al., 2014). }\end{array}$ & $\begin{array}{l}\text { Mentha-2, 8-diene- } \\
\text { 1-ol trans-para }\end{array}$ & $\begin{array}{l}\text { Mentha-2, 8-diene-1-ol trans-para is a biologically active } \\
\text { compound found in lemon grass and it possesses strong } \\
\text { antimicrobial properties. }\end{array}$ \\
\hline $\begin{array}{l}\text { (Farangh et al., 2013), } \\
\text { (Nanon et al., 2014). }\end{array}$ & $\begin{array}{l}\text { Mentha-1 (7), 8- } \\
\text { dien-2-ol trans }\end{array}$ & $\begin{array}{l}\text { Mentha-1 (7), 8-dien-2-ol trans is a biologically active } \\
\text { compound found in lemon grass and it possesses } \\
\text { antimicrobial properties. }\end{array}$ \\
\hline $\begin{array}{l}\text { (Farangh et al., 2013), } \\
\text { (Nanon et al., 2014). }\end{array}$ & $\begin{array}{l}\text { Mentha-2, 8-diene- } \\
\text { 1-ol cis-para }\end{array}$ & $\begin{array}{l}\text { Mentha-2, 8-diene-1-ol cis-para is a biologically active } \\
\text { compound found in lemon grass and it possesses strong } \\
\text { antimicrobial properties. }\end{array}$ \\
\hline
\end{tabular}

\section{Discussion:}

Medicinal and herbal plants have been utilized for decades in traditional medicine worldwide. The dynamic behind using medicinal and herbal plants interlinks phytochemistry and plant biology and are more concerned with the evolution mechanisms and the systematics of medicinal and herbal plant genomes, the origin and the 
evolution of plant genotypes and the metabolic phenotype. It also considers the interaction between medicinal and herbal plant genomes and environment and a correlation between the genomic diversity and the metabolite diversity among many other important aspects. The utility in the fields of molecular phylogeny and phylogenomic is integral in predicting the chemo-diversity of natural product-based drug that have been developed over the years (Food and Nutrition Research, 2012).

According to the first $\left(1^{\text {st }}\right)$ table, the properties of Azadirachta indica was evaluated and it was found that $A$. indica possessed great potential since eighteen (18) different properties were noted. These properties are: antimicrobial activities where is works against a variety of bacteria (e.g., Klebsiella serratia and Streptcoccus, Vibrio cholera, Escherichia coli, Bacillus subltilis, Enterococcus faecalis and Streptococcus faecalis.), fungi (e.g., Monilinia fruticola, Penicillium expansum, Trichothecium roseum, Alternaria spp., Aspergillus flavus, Aspergillus fumigatus, Aspergillus niger, Aspergillus terreus, Candida albicans and Microsporum gypseum) and virus (e.g., coxsackievirus virus B-4, small pox, fowl pox, polio and HIV) species, anti-dengue activity, antimalarial activity, antifeedant activity (larvicidal activity), anti-ulcerative activity, hypoglycemic activity (antidiabetic activity), immuno-stimulant activity, antioxidant activity, anticancer activity, antifertility activity, wound healing effect, hepatoprotective effect, neuroprotective effect, cardioprotective effect, pesticide activity, dermatological effect, anti-inflammatory, antipyretic and analgesic activities and it plays a significant role in dentistry.

The information in table two (2) demonstrated the properties of Ocimum tenuiflorum. O. tenuiflorum was noted to possess twelve (12) properties which are: antitissue activity, hypoglycemic activity (antidiabetic activity), anticancer agent, anti-hyperlipidemic activity, antifertility agent, immunomodulatory agent, stress releasing agent, analgesic activity, larvicidal, pupicidal and adulticidal potential, wound healing activity, antiinflammatory activity and antimicrobial activity against a range of bacteria (e.g., Escherichia coli, Salmonella

typhi, Pseudomonas pyocyaneus, Vibrio cholerae, Shigella dysenteriae and Proteus vulgaris), fungi (e.g., Micosporum canis, Micosporum gypseum, Trichophyton rubrum and Trichophyton mentagrophytes) and virus (e.g., against DNA virus (Herpes Virus-HSV, Adenovirus-ADV and Hepatitis-B virus) and RNA viruses).

From table three (3), six (6) properties of Cymbopogon citratus was reported on which are as follow: antiinflammatory responses, antioxidant activity, antibacterial potential, anti-obesity and antihypertensive activity, anxiolytic property and antifungal potential.

On the other hand, table four (4) demonstrates the phytochemicals and their biological activities present in Azadirachta indica. A total of sixty-five (65) biologically active compound was reported on. Among them, many of the major compounds that are responsible for the potential of neem were noted such as: azadirachtin, nimbin, terpenoids, tannins, alkaloids, ascorbic acid, amino acid, nimbolide etc. and many minor chemical constituients.

The information presented on table (5) relates the phytochemicals and the biological activities they possess in Ocimum tenuiflorum. A total of eighty-two (82) biologically active compounds were extracted including its main compounds such as: eugenol, oleanolic acid, ursolic acid, rosmarinic acid, carvacrol, linalool and $\beta$ caryophyllene and other supportive chemical compounds that are responsible for the therapeutic abilities possessed by this plant.

The final table demonstrates the phytochemicals and their biological activities present in Cymbopogon citratus. Sixty-four (64) biologically active compounds were collected including the major compounds (geranial, neral and myrcene) which are responsible for the major activities exhibited by this plant.

\section{Conclusion:}

It can therefore be concluded that medicinal and herbal plants possess a lot of therapeutic properties that can be used to resolve many global issues e.g., certain diseases that are considered chronic and others that are caused by microbial organisms such as: bacteria, fungi and virus that are very prevalent among people of today's society. However, more work scientific works like extensive laboratory testing and biological analysis should be done with these plants to determine the plants full potential e.g., using the Cymbopogon citratus as the key 
solution against various pathogenic infections and chronic diseases that this plant was not tested against and try to identify more properties that the plant possess instead of the six (6) that was evaluated in this review. In addition, these potential properties that these plants possess are because of the wide range of phytochemicals that are present in the plants that have been synthesized over the many years of plant evolution and development in history. Furthermore, two (2) of the three (3) plants (Neem and Tulsi) that was evaluated in this research is found to be very useful in this time of pandemic against the SARS-CoV-2 (COVID-19 Virus). It is because each of these phytochemicals possess one or multiple biological activities that significantly contribute to the plant's success in the world of medicine and pharmaceuticals. Therefore, researchers, practitioners and other qualified personnel working with medicinal and herbal plants should be more vigilant in the identification, utilization and management so as to achieve the maximum potential and therapeutic benefits offered by these plants.

\section{Beneficiaries:}

Based on the information assessed and obtained, this review paper can be utilized by the following:
$\checkmark$ University of Guyana (UG)
$\checkmark$ Students
$\checkmark$ Ministry of Public Health
$\checkmark$ Guyana Pharmaceutical Corporation
$\checkmark$ Guyana Dental Service
$\checkmark$ Guyana Food Safety Authority
$\checkmark$ Guyana World Health Organization
$\checkmark$ Guyana School of Agriculture (G.S.A)
$\checkmark$ National Agricultural Research and Extension Institute (NAREI)
$\checkmark$ Members of the Local Community
$\checkmark$ Members of the Wider Community

The Ministry of Public Health and Ministry of Agriculture, Guyana can utilize this research and carry out tests to identify the phytochemical constituents and assess the therapeutic properties of these medicinal and herbal plants in Guyana.

\section{Acknowledgement}

I would like to express my humblest of gratitude to several of the individuals whom have supported me through out my final year research project.

Firstly, I thank God the Almighty for giving me health and strength through this COVID-19 pandemic. I am thankful for having the opportunity to see this project successfully completed. Sincerest gratitude goes out to my supervisors, Mrs. Ferial Pestano-Gupta and Mrs. Zenesia Phillips-Henry, for their time, patience, comments, passion, insights, supportive information, critiques and continuous ideas and rigorous advice that have helped me greatly at all times throughout my research. Their professionalism, knowledge and experience in research has allowed me to complete this research successfully. Without your guidance and support, the completion of this project would not have been possible.

I am also personally expressing a heartfelt thank you to my research assistant: Mr. Rahaman Balkarran whom has been continuously supporting me since the commencement of this research. I am eternally grateful to you because I can always count on you for your input. Your time, patience, knowledge, wisdom and passion kept willing me on to complete this research.

I am deeply grateful to my parents because their financial support and everyday motivation has enabled me to complete my BSc studies successfully. I am also very thankful for the few supportive friends I have, who were there from the start. Your thoughts and prayers were necessary for completing this project. 
In addition, I would like to express my sincerest of appreciation to the University of Guyana for accepting me into the Bachelors of Science-Biology program. My time spent here was fruitful and fulfilling, since I gained wealth of knowledge, made interesting friends and would forever be filled with endless memories.

A final thanks to Ms. Chalasa Cossiah and Mr. Dharamdeo Singh for supervisory work done during my proposal. Mr. Phillip Da Silva, much gratitude to you, for your consistent support and assistance in every way possible.

Thank you all for your encouragement!

\section{Disclosure of conflict of interest}

The authors hereby declare that this manuscript does not have any conflict of interest.

\section{References (APA $6^{\text {th }}$ Edition)}

1. Abbas, H. \& Hassan, V. N. (2003). Chemical constituents and efficacy of Cymbopogon olivieri (BOISS). Bar essential oil against Malaria. DARU, 11.pg. 125-128. Journal of Molecules, 20, 7438-7453.

2. Abstrax Tech. (2019). What is Terpinolene and What Are Its Benefits? Retrieved from: https://abstraxtech.com/blogs/learn/what-is-terpinolene-and-what-are-its-benefits.

3. Abstrax Tech. (2021). What is Geraniol? 9 Powerful Uses and Benefits of this Potent Terpene. Retrieved from: https://abstraxtech.com/blogs/learn/what-is-geraniol-uses-benefits.

4. Adejuwon, A. A. \& Esther, O. A. (2007). Hypoglycemic and hypolipidemic effects of fresh aqueous extract of Cymbopogon citratus Stapf in rats. Journal of Ethnopharmacology. 112. pg. 440-444.

5. Ahmad, A.; Javed, M. R.; Rao, A. Q. \& Husnain, T. (2016). Designing and screening of universal drugs from neem (Azadirachta indica) and standard drug chemicals against influenza virus nucleoprotein. BMC Complement Altern. Med. 16 (1).pg. 519.

6. Ahmad, R.; Misra, A.; Trivedi, A. et al. (2017). Evaluation of In Vitro Cytotoxic activity of ethanolic extract of Azadirachta indica leaves as a function of $\mathrm{pH}$ on human breast cancer cell line MDA-MB 231. J. Basic Clin Pharma. 8. pg. 72-79.

7. Ahmad, S.; Maqbool, A.; Srivastava, A. et al. (2019). Biological detail and therapheutic effect of Azadirachta indica (neem tree) products-A Review. J. Evid. Based. Med. Healthc. 6 (22). pg. 1607-1612.

8. Aibinu, I.; Adenipekun, T.; Adelowowtan, T.; Ogunsanya, T.; \& Ogungbemi, T. (2007). Evaluation of the Antimicrobial Properties of Different Parts of Citrus aurantifolia (lime fruit) as used locally. Afr. Biotechnol. 2, pg. 185-190. Journal of Molecules, 20, 7438-7453.

9. Akin-Osanaiya, B. C.; Nok, A. J.; Ibrahim, S. et al. (2013). Antimalaria effect of neem leaf and neem stem bark extracts on Plasmodium berghei infected in the pathology and treatment of malaria. International Journal of Research in Biochemistry and Biophysics. 3 (1). pg. 7-14.

10. Ali, A. (1993). Phytochemicals of Azadirachta Source of Active Medicinal Constituent Used for Cure of Various Diseases: A Review. Textbook of Pharmacognosy, Publication and Information Directorate, New Dheli, India. Journal of Scientific Research, Vol. 64, 2020.

11. Ali, M.; Mashud, M.; Rubel, M. et al. (2013). Biodiesel from Neem Oil as an Alternative Fuel for Diesel Engine. Procedia Engineering. 56: 625-630 pg.

12. Ali, N. A. A.; Chhertri, B. K.; Dosoky, N. S.; Shari, K.; Al-Fahad, A. J. A.; Wessjohann, L. \& Setzer, W. N. (2017). Antimicrobial, Antioxidant, and Cytotoxic Activities of Ocimum forskolei and Teucrium yemense (Lamiaceae) Essential Oils. Retrieved https://www.ncbi.nlm.nih.gov/pmc/articles/PMC5590053/.

13. Ali, R. \& El-Anany, A. (2017). Stabilization of Neem Oil Biodiesel with Corn Silk Extract during Long term Storage. Journal of Oleo Science. 66 (2):133-145.

14. Ali, R. \& El-Annay, A. (2017). Stabilization of Neem Oil Biodisel with Corn Silk Extract during Long Term Storage. Journal of Oleo Science. 66(2): 133-145.

15. Almas, K. (1999). The antimicrobial effects of extracts of Azadirachta indica (Neem) and Salvadora Persica (Arak) chewing stick extract. Int. J. Den. Res. 10. pg. 23-26. 
16. Alzohairy, M. A. (2016). Therapeutics Role of Azadirachta indica (Neem) and Their Active Constituents in Diseases Prevention and Treatment. Retrieved from: https://www.hindawi.com/journals/ecam/2016/7382506/.

17. American Chemical Society. (2017). $\alpha$-Terpineol. Retrieved from: https://www.acs.org/content/acs/en/molecule-of-the-week/archive/t/alpha-terpineol.html.

18. American Chemical Society. (2021). Camphene. Retrieved from: https://www.acs.org/content/acs/en/molecule-of-the-week/archive/c/camphene.html.

19. Amoah, S. K. S.; Sandjo, L. P.; Kratz, J. M. \& Biavatti, M. V. (2016). Rosmarinic Acid-Pharmaceutical and Clinical Aspects, Planta Med. 82 (5). pg. 288-406. Retrieved from: http://dx.doi.org/10.1155/s-00351568274.

20. Ansari, K. A. (2015). Study of Plant Tulsi and its benefit for human beings. International Journal of Applied Research. 1(3): 148-151.

21. Armstrong, P.; Morchesky, Z.; Hess, D. et al. (2014). Production of High Surface Area Activated Carbon from Coconut Husk. MRS Proceedings. pg. 16-44.

22. Avetisyan, A.; Markosian, A.; Petrosyan, M.; Sahakyan, N.; Babayan, A.; Aloyan, S. \& Trchounian, A. (2017). Chemical composition and some biological activities of the essential oils from basil Ocimum different cultivars. Retrieved from: https://bmccomplementmedtherapies.biomedcentral.com/articles/10.1186/s12906-017-1587-5.

23. Awashti, P. K. \& Dixit, S. C. (2007). Chemical Composition of Ocimum sanctum Shyama and Ocimum sanctum Rama oils from the plains of Northern India. Journal of Essential Oil-Bearing Plants. 10: 292296. Journal of Pharmacognosy and Phytochemistry; 6(2): 261-264. Retrieved from: http://dx.doi.org/10.1080/10412905.2005.9699025.

24. Ayeleso, T. B.; Matumba, M. G. \& and Mukwevho, E. (2017). Oleanolic Acid and Its Derivatives: Biological Activities and Therapeutic Potential in Chronic Diseases. Retrieved from: https://www.ncbi.nlm.nih.gov/pmc/articles/PMC6150249/.

25. Badam, L.; Joshi, S. P. \& Bedekar, S. S. (1999). In vitro antiviral activity of neem (Azadirachta indica. A. Juss) leaf extract against group B coxsackievirus. Journal of Communicable Disease. 31 (2). pg. 79-90.

26. Bagheri, R.; Durrheim, D. N.; Abkar, A. \& Fazlollahi, A. (2007). Essential Oil Components of Cymbopogon parkeri STAPF from Iran. Pak. J. Bio. Sci, 10. pg. 3485-3486. Journal of Molecules, 20, 7438-7453

27. Bahadur, S. \& Chhetri, B. (2020). Reducing Sugar, Total Phenolic Content, and Antioxidant Potential of Nepalese Plants. Retrieved from: https://www.hindawi.com/journals/bmri/2020/7296859/.

28. Balachandra, P.\& Govindarajan, R. (2005). Cancer-an ayurvedic perspective. Pharmocol. 51: 19-30 pg.

29. Baligar, N. S.; Aladakatti, R. H.; Ahmed, M. \& Hiremath, M. B. (2014). Hepatoprotective activity of the neem-based constituent Azadirachta-A in carbon tetrachloride intoxicated Wistar rats. Indian J. Pharmacol. 93.pg. 267-277.

30. Barnett, A. (2006). "The New Piracy in Africa”. Guardian Weekly (UK).

31. Belewu, M. A.; Olatunde, O. A. \& Giwa, T. A. (2009). Underutilized medicinal plants and spices: Chemical composition and phytochemical properties. Retrieved from: https://academicjournals.org/journal/JMPR/article-full-text-pdf/B8E59EF15478.

32. Bhajoni, P. S. \& Meshram, G. G. (2016). Evaluation of the Antiulcer Activity of the Leaves of Azadirachta indica. An experimental Study. Integr. Med. Int. 3. pg. 5-8.

33. Bhargava, K. P. \& Singh, N. (1981). Anti-stress activity of O. sanctum. Indian Journal of Medicinal Research. 73. pg. 443-451.

34. Bhargava, K. P.; Gupta, M. B.; Gupta, G. P. \& Mitra, C. R. (1970). Anti-inflammatory activity of saponins and other natural products. India J Med Res. 58(6): 724. Pharmacognosy Journal: Review Article, 2019. 
35. Bharti, S. K.; Kumar, A.; Prakash, O.; Krishnan, S. \& Gupta, A. K. (2013). Essential oil of Cymbopogon citratus against diabetes: validation by in-vivo experiments and computational studies. J. Bioanal. Biomed. 5 (2013). pg. 194-203. Scientific African Vol. 6. (2019).

36. Bhattacharya, A. K.; Kaul, P. N. \& Rajeswara, Rao B. R. (1996). Essential Oils of Ocimum gratissimum L. and Ocimum tenuiflorum L. (Syn. Ocimum sanctum L.) grown in Andhra Pradesh. India Perfumer. 40; 73-75. Journal of Pharmacognosy and Phytochemistry; 6(2): 261-

37. Bhattacharya, A.; Sood, P. \& Citovsky, V. (2010). The roles of plant phenolics in defence and communication during Agrobacterium and Rhizobium infection. Retrieved from: https://pubmed.ncbi.nlm.nih.gov/20696007/\#: :text=Phenolics\%20are\%20aromatic\%20benzene\%20ring, mainly\%20for\%20protection\%20against\%20stress.\&text=Phenolics\%20play\%20important\%20roles\%20i n,and $\% 20$ scaffolding\%20support $\% 20$ to $\% 20$ plants.

38. Bhuiyan, M. M.; Nishimura, M.; Matsmura, S. \& Shimou, T. (1997). Antibacterial effect of crude Azadirachta indica neem bark extract on Streptococcus sobrinus. Pediatr. Dent. J. 7. pg. 61-64.

39. Bidinotto, L. T.; Costa, C. A. R. A.; Salvadori, D. M. F.; Costa, M.; Rodrigues, M. A. M. \& Barbisan, L. F. (2011). Protective effects of lemongrass (Cymbopogon citratus StapF) essential oil on DNA damage and carcinogenesis in female Balb/C mice. Journal of Applied Toxicology. 31.pg. 536-534.

40. Biomedicine \& Pharmacotherapy. (2018). Chlorogenic acid (CGA): A pharmacological review and call for further research. Retrieved from: https://www.sciencedirect.com/science/article/abs/pii/S0753332217339963\#: :text=CGA\%20is\%20an\%2 0important\%20and,\%2C\%20anti\%2Dhypertension\%2C\%20free\%20radicals.

41. Biswa, K.; Chattopadhay I.; Banerjee, R. \& Bandyopadhay, U. (2002). Biological activities and medicinal properties of neem (Azadirachta indica). Current Science. 82(11): 1336-1345. Pharmacognosy Journal: Review Article, 2019.

42. Bohora, A.; Hedge, V. \& Kokate, S. (2010). Comparison of Antimicrobial efficacy of neem leaf extract and $2 \%$ sodium chlorite against E. faecalis, C. albicans and mixed culture-An In Vitro study. Endodontology. 22. pg. 8-12.

43. Borah, R. \& Biswas, S. P. (2018). Tulsi (Ocimum sanctum), excellent source of phytochemicals. International Journal of Environment, Agriculture and Biotechnology. Vol. 3. pg. 1734-1738.

44. Borkotoky, S. \& Banerjee, M. (2020). A computational prediction of SARS-CoV-2 structural protein inhibitors from Azadirachta indica (neem). J. Biomol. Struct. Dyn., 1-11. doi:10.1080/07391102.2020.1774419

45. Botanic Gardens Conservation International. (1996). "CITES and Medicinal Plants Study: A Summary of Findings.”. Retrieved from: www.bgci.org/wellbeing/CITES_and_Med_Plants_Sumary/.

46. Brophy, J. J.; Goldslack, R. J. \& Clarkson, J. R. (1993). The essential oil of Ocimum tenuiflorum L. (Lamiaceae) growing in Northern Australia. Journal of Essential Oil-Bearing Plants. 10: 292-296. Journal of Pharmacognosy and Phytochemistry; 6(2): 261-264. Retrieved from: http://dx.doi.org/10.1080/10412905.2005.9699025.

47. Brugger, P. B.; Martinez, L. C.; Plata-Rueda, A.; de Castro e Castro, B. M; Soares, M. A.; Wilchen, C. F; Carvalho, A. G.; Serrao, J. E. \& Zanuncio, J. C. (2019). Biological Activity of the Cymbopogon citratus (Poaceae) essential oil and its terpenoid constituents on the predatory bug, Podisus ningrispinus (Heteroptera: Pentatomidae). Scientific Papers. 9: 8358. Retrieved from: https://doi.org./10.1038/s41598019-44709-y.

48. Brugnatelli, V. (2021). Anti-inflammatory \& anti-nociceptive properties of $\beta$-myrcene. Retrieved from: https://www.fundacion-canna.es/en/anti-inflammatory-anti-nociceptive-properties-v-myrcene.

49. Burkill, I. H. (1935). A Dictionary on Economic Products of Malay Peninsula Crown Agents of Colonies, London, 2, 276.

50. Byju Classes. (2021). Polysaccharides. Retrieved from: https://byjus.com/biology/polysaccharides/. 
51. Calabrese, E. J. \& Baldwin, L. A. (2003). Hormesis: the dose response revolution. Annual review of Pharmacology and Toxicology. 43: pg. 175-197.

52. Carlin, E.; Contar, J.de.; \& Silva-Filho, D. P. (1986). Pharmacology of Lemon Grass (Cymbopogon citratus Stapf) 1 Effects of teas prepared from leaves on laboratory animals. J. Ethnopharmacology, 17 (1): 37-64.

53. Carrubba, A. \& Scalenghe, R. (2012). Scent of Mare Nostrum-Medicinal or Aromatic Plants (MAPs) in Mediterranean soils. Journal of the Science of Food and Agriculture. 96 (2): 1150-1170. doi:10.1002/jsfa.5630. Retrieved from: https://www.researchgate.net/publication/337649086_Medicinal_Plants_the_Medical_Food_and_Nutritio nal_Biochemistry_and_Uses/link/5e5805b44585152ce8f491d9/download.

54. Carter, A. (2019). Ferulic Acid: The Antioxidant-Boosting Skin Care Ingredient. Retrieved from: https://www.healthline.com/health/ferulic-acid.

55. Chadha, K. L. \& Gupta, R. (1995). Medicinal and Aromatic Plants. Advances in Horticulture (Vol 11). Malhotra Publishing House, New Delhi, page 932. Retrieved from: https://www.researchgate.net/publication/270338632_Medicinal_Plants_in_Tropical_Homegardens/link/5 5b6146408aed621de030b84/download.

56. Chattopadhyay, I.; Nandi, B.; Chatterjee, R. et al. (2004). Mechanism of antiulcer effect of Neem (Azadirachta indica) leaf extract: effect on H+-K+-ATPase, oxidative damage and apoptosis. Inflammopharmacology. 12 (2). pg. 153-176.

57. Chattopadhyay, Y. R. R. (1993). Hypoglycemic effect of O. sanctum leaf extract in normal and streptozotocin diabetic rats. International Journal of Experimental Biology. 31. pg. 891-893.

58. Chava, V. R.; Manjunath, S. M.; Rajanikanth, A. V. \& Sridevi N. (2012). The efficacy of neem extract on four microorganisms responsible for causing dental caries viz Streptococcus mutans, Streptococcus salivarus, Streptococcus mitis and Streptococcus sanguis: An In Vitro Study. J. Contempt. Dent. Pract. 13. pg. 269-272.

59. ChEBI.

(2019).

4-terpineol.

Retrieved

from: https://www.ebi.ac.uk/chebi/searchId.do?chebiId=CHEBI:78884.

60. ChEBI. (2021). geranyl acetate. Retrieved from: https://www.ebi.ac.uk/chebi/searchId.do?chebiId=CHEBI:5331.

61. Cheel, J.; Theoduloz, C.; Rodreguez, J. \& Schmeda, H. G. (2005). Free radical scavengers and antioxidants from lemon grass (Cymbopogon citratus (DC.) Stapf.). Journal of Agricultural and Food Chemistry. 53. pg. 2511-2517.

62. Chem Spider. (2021). (E)- $\alpha$-bisabolene. Retrieved from: http://www.chemspider.com/ChemicalStructure.4474766.html.

63. Chen, A. Y. \& Chen, Y. C. (2013). A review of the dietary flavonoid, kaempferol on human health and cancer chemoprevention. Retrieved from: https://www.ncbi.nlm.nih.gov/pmc/articles/PMC3601579/.

64. Chiang, L. C.; Ng, L.T.; Cheng, P. W. \& Lin, C. (2005). Antiviral activities of extracts and selected pure constituents of Ocimum sanctum. Clinical and Experimental Pharmacology and Physiology. 32 (10). pg. 811-816.

65. Chiew, I. K. M. (2018). Underutilized plant species: What are they? Retrieved from: https://www.researchgate.net/publication/305317614_Underutilized_plant_species_What_are_they.

66. Chin, P. (2019). Lemongrass. Retrieved from: https://www.stabroeknews.com/2019/06/30/sunday/in-thegarden/lemongrass/.

67. Chopra, R. N.; Nayer, S. L. \& Chopra, I. C. (1956). Glossary of India Medicinal Plants. New Dheli, India: CSIR.

68. Chundran, N. V.; Husen, I. R. \& Rubanati, I. (2015). Effect of Neem Extract (Azadirachta indica) on Wound Healing. AMJ. 2. pg. 199-207. 
69. Cleveland Clinic.

(2019).

Phytosterols.

Retrieved

from:

https://my.clevelandclinic.org/health/articles/17368-phytosterols-sterols--stanols.

70. Conte Jr, A. J. E. (1997). Novel approach to preventing insect-borne diseases. $N$ Engl J Med.;337(11):785-6. doi: 10.1056/NEJM199709113371112.

71. Costa, A. V.; Pinherio, V. M.; Rondelli, V. T.; De Queiroz, A. C.; Tuler, K. B. \& Brito, D. P. (2013). Cymbopogon citratus (Poaceae) essential oil on Frankliniella schulizei (Thysanoptera: Thripidae) and Myzus persicae (Hemiptera: Aphididae). Biosci. J. 29 (2013). pg. 1840-1847. Scientific African Vol. 6. (2019).

72. Costa, C. A. R. A.; Gargano, A. C. \& Costa, M. (2006). Anxiolytic-like effect of the essential oil of Cymbopogon citratus in experimental procedures in mice. European Neuro Psychopharmacology. 16: S445-S1475.

73. Critchley, K. (2019). 10 Plants \& Herbs that Help Keep the Pests Away. Retrieved from: https://langslawncare.com/blog/outdoor-pest-control/10-plants-herbs-keep-pests-bugs-away/.

74. Cushnie, T. P. \& Lamb, A. J. (2005). Antimicrobial Activity of Flavonoids. International Journal of Antimicrobial agents. 26 (5).pg. 342-356.

75. Cusnu, K. \& Basar, C. (2008). Biological and pharmacological activities of carvacrol and carvacrol bearing essential oils. Retrieved from: https://pubmed.ncbi.nlm.nih.gov/19075694/\#: :text=Many\%20diverse\%20activities\%20of\%20carvacrol,s uch\%20as\%20feed\%20additive\%2C\%20in.

76. Da Silva, D. T.; Araujo, A. D.; Moraes, A. M.; De Souza, L. A.; Lourenco, M. C. S.; De Souza, M. V. N.; Wardwell, J. L. \& Wardwell, S. M. S. V. (2016). Synthesis and Biological Activities of Camphor Hydrazone and Imine Derivatives. Retrieved https://www.ncbi.nlm.nih.gov/pmc/articles/PMC5064238/\#: :text=In\%20the\%20medical\%20chemistry\% 20field,and\%20analgesic\%20agent\%20\%5B8\%5D.

77. Dahham, S. S.; Tabana, Y. M.; Iqbal, M. A.; Ahamed, M. B. K.; Ezzat, M. O.; Majid, A. S. A. \& Majid, A. M. S. A. (2015). The Anticancer, Antioxidant and Antimicrobial Properties of the Sesquiterpene $\beta$ Caryophyllene from the Essential Oil of Aquilaria crassna. Retrieved from: https://www.ncbi.nlm.nih.gov/pmc/articles/PMC6331975/\#: :text=The\%20structure\%20of\%20\%CE\%B2 $\%$ 2Dcaryophyllene, \%2DIR\%2C\%20NMR\%20and\%20MS.\&text=Results\%20showed\%20that $\% 20 \% \mathrm{CE}$ $\%$ B2\%2Dcaryophyllene, also\%20displayed\%20strong\%20antioxidant\%20effects.

78. Daily, G. (1997). Nature's Services: Societal Dependence on Natural Ecosystems. Covelo, CA: Island Press. 392 pp.

79. Dash, S. P.; Dixit, S. \& Sahoo, S. (2017). Phytochemical and Biochemical Characterizations from Leaf Extracts from Azadirachta indica: An Important Medicinal Plant. Biochemistry and Analytical Biochemistry.

80. De Lira, M. H. P.; De Andrade Junior, F. P.; Moraes, G. F. Q.; Macena, G. D. S.; Periera, F. D. O. \& Lima, I. O. (2020). Antimicrobial activity of geraniol: an integrative review. Retrieved from: https://www.tandfonline.com/doi/abs/10.1080/10412905.2020.1745697?journalCode=tjeo20.

81. Desai, M. A. \& Parikh, J. (2012). Microwave assisted extraction of essential oil from Cymbopogon flexuosus (Steud.) wats: A parametric and comparative study. Sep. Sci. Technol. 47. pg. 1963-1970. Journal of Molecules, 20, 7438-7453

82. Dhanya, K. N. M. \& Sidhu, P. (2013). The antimicrobial activity of Azadirachta indica, Glycyrrhiza glabra, Cinammm zeylanicum, Syzygium aromaticum, Accacia nilotica on Streptococcus mutans and Enterococcus faecalis-An In Vitro Study. Endodontology. Retrieved from: http://medind.nic.in/eaa/t11/i1/eaat11i1p16.pdf.

83. Dharmananda, S. (1997). The Methods of Preparation of Herbs Formula: Decoctions, Dried Decoctions, Powders, Pills, Tablets, and Tinctures. Institute of Traditional Medicine, Portland, Oregon. Retrieved from: 
https://www.researchgate.net/publication/337649086_Medicinal_Plants_the_Medical_Food_and_Nutritio nal_Biochemistry_and_Uses/link/5e5805b44585152ce8f491d9/download.

84. Dharmendra, S.; Suman, P. S. K.; Atul, P. K.; Subhash, C. G. \& Sushil, K. (2001). Comparative Antifungal Activity of essential oils and constituents from three distinct genotypes of Cymbopogon spp. Current Science 80. pg. 1264-1266.

85. Dholi, S. K.; Raparla, R.; Mankala, S. K. et al. (2011). In vivo Anti-diabetic evaluation of Neem leaf extract in alloxan induced rats. Journal of Applied Pharmaceutical Science. 1 (4). pg. 100-105.

86. Do Rego, J. C.; Ortha, M. H.; Leprince, J.; Tonon, M. C.; Vaudry, H. \& Cotentin, J. (2007). Pharmacological characterization of the receptor mediating the anorexigenic action of the octadecaneuropeptide: evidence for an endozepinergic tone regulating food intake. Neuropsychopharmacology 32.pg. 1641-1648.

87. Doctor NDTV. (2019). 7 Best Medicinal Plants and Their Uses. Retrieved from: https://doctor.ndtv.com/living-healthy/7-best-medicinal-plants-and-their-uses-1826198.

88. Dubey, R.; Patil, K.; Dantu, S. et al. (2019). Azadirachtin inhibits amyloid formation, disaggregate preformed fibrils and protects pancreatic -cells from human islet amyloid polypeptidel amylin-induced cytotoxicity. Biochemical Journal. 476. pg. 889-907.

89. Durrani, F. R.; Chand, N.; Jan, A. et al. (2009). Immunomodulatory and growth promoting effects of neem leaves infusion in broiler chicks. Agric. 24 (4). pg. 655-660.

90. Dwivedi, V. D.; Tripathi, I. P. \& Mishra, S. K. (2016). In silico evaluation of inhibitory potential of triterpenoids from Azadirachta indica against therapeutic target of dengue virus, NS2B-NS3 protease. J. Vector Borne Dis. 53 (2). pg. 151-161.

91. Dyal. P. (2019). THE HEALTH BENEFITS OF MINT AND TULSI. Retrieved from: https://guyanachronicle.com/2019/08/25/the-health-benefits-of-mint-and-tulsi/.

92. EGW's Skin Care. (2021). Citronellol. Retrieved from: https://www.ewg.org/skindeep/ingredients/701389-citronellol/.

93. Elavarasu, S.; Abinaya, P.; Elanchezhiyan, S.; Thangakumaran, V. K. \& Naziya, K. B. (2012). Evaluation of Anti-plaque microbial activity of Azadirachta indica (Neem oil) In Vitro: A pilot study. J. Pharm. Bioallied Sci. 90. pg. 394-396.

94. Encyclopedia Britannica. (2021). Borneol Chemical Compound. Retrieved from: https://www.britannica.com/science/borneol.

95. Encyclopedia Britannica. (2021). https://www.britannica.com/science/glycoside.

96. Encyclopedia Britannica. (2021). Phthalic acid. Retrieved from: https://www.britannica.com/science/phthalic-acid.

97. Export and Import Bank of India (EXIM Bank). (2003). Export potential of Indian medicinal plants and products. Publication NO. OP 98. Export and Import Bank of India (EXIM Bank), Mumbai India (see also www.eximbankindia.com/publications). Retrieved from: https://www.researchgate.net/publication/270338632_Medicinal_Plants_in_Tropical_Homegardens/link/5 5b6146408aed621de030b84/download.

98. Eyo, L. E.; Uzoibiam, B. O.; Ogbanya, K. C. \& Nnaji, T. O. (2014). Comparative evaluation of wound healing effects of Ocimum gratissimum, Vernonia amygdaline and Zingiber officinalis extracts on incision wound model in rats. Pharmacology online. 3. pg. 44-50.

99. Fakim, A. G. (2006). Medicinal plants: Traditions of yesterday and drugs of tomorrow. Molecular aspects of medicine 27: 1-93. Retrieved from: http://www.phytopharmajournal.com/Vol6_Issue6_08.pdf.

100.Fandohan, P.; Gnonlonfin, B.; Laleye, A.; Gbenou, J. D.; Darboux, R. \& Moudachirou, M. (2008). Toxicity and gastric tolerance of essential oils from Cymbopogon citratus, Ocimum gratissimum and Ocimum bascilium in Wistar rats. Food and Chemical Toxicology. 46. pg. 2493-2497. 
101. Farhang, V.; Amini, J.; Javadi, T.; Nazemi, J. \& Ebadoollahi, A. (2013). Chemical composition and antifungal activity of essential oil on Cymbopogon citratus (DC.) Stapf. against three Phytophthora species. Greener J. Biol. Sci. 3 (2013). pg. 292-298. Scientific African Vol. 6. (2019).

102. Farnsworth, N. R. \& Soejarto, D. D. (1991). Global Importance of Medicinal Plants. In Akeele, O.; Haywood, V.; and Synge, H. (eds), The conservation of medicinal plants, pp 25-51. Cambridge University Press, Cambridge. Retrieved from: https://www.researchgate.net/publication/270338632_Medicinal_Plants_in_Tropical_Homegardens/link/ 55b6146408aed621de030b84/download.

103. Figueirinha, A.; Cruz, M.; T.; Francisco, V.; Lopes, M. C. \& Batista, M. T. (2010). Anti-inflammatory activity of Cymbopogon citratus leaf infusion in lipopolysaccharide-stimulated dendritic cells: contribute of the polyphenols. Journal of Medicinal Food. 13. pg. 681-690.

104. Figueirinha, A.; Paranhos, A.; Perez-Alonso, J. J.; Santos-Buelga, C. \& Batista, M. T. (2008). Cymbopogon citratus leaves. Characterisation of flavonoids by HPLC-PDA-ESI/MS and an approach to their potential as a source of bioactive polyphenols. F.d. Chem, 110, 718-728.

105. Food and Agricultural Organization (FAO). (1996). Forest, Food and Health. Retrieved from: http://www.fao.org/forestry/en/.

106. Food and Nutrition Research. (2012). Medicinal Plants. Retrieved from: https://www.sciencedirect.com/topics/agricultural-and-biological-sciences/medicinal-plants.

107. FoodB. (2021). Showing Compound beta-Bisabolene (FDB014800). Retrieved from: https://foodb.ca/compounds/FDB014800.

108. Francine, U.; Jeannette, U. \& Pierre, R. J. (2015). Assessment of Antibacterial activity of neem plant (Azadirachta indica) on Staphylococcus areus and Escherichia coli. J. Med. Plants Stud. 3 (4). pg. 8591.

109. Francisco, V., Figueirinha, A.; Neves, B. M.; Garcia-Rodriguez, M. C.; Lopes, M. C.; Cruz, M. T. \& Batista, M. T. (2011). Cymbopogon citratus as a source of new safe anti-inflammatory drugs: bioguided assay using lipopolysaccharide-stimulated macrophages. Journal of Ethnopharmacology. 133. pg. 818-827.

110. Freeborn, D. \& Garilli, B. (2020). A Guide to Common Medicinal Herbs. Retrieved from: https://www.urmc.rochester.edu/encyclopedia/content.aspx?contenttypeid=1\&contentid=1169.

111. Frontiers in Oncology. (2019). Chemical and Pharmacological Aspects of Caffeic Acid and Its Activity in Hepatocarcinoma. Retrieved https://www.frontiersin.org/articles/10.3389/fonc.2019.00541/full\#: :text=Caffeic\%20acid\%20(CA)\%2 0is\%20a,anti\%2Dinflammatory\%20and\%20anticarcinogenic\%20activity.

112.Fujiwara, T.; Sugishita, E. Y.; Takeda, Y.; Shimizu, M.; Nomura, T. \& Tromita, Y. (1981). Further studies on the structures of polysaccharides from the bark of Melia Azadirachta. Chem. Pharmacol. Bull., 32: 1385-1391.

113. Gardenia. (2021). Cymbopogon citratus (Lemon Grass). [Image]. Retrieved from: https://www.google.com/search?q=Cymbopogon+citratus\&rlz=1C1EJFC_enCA803CA803\&hl=en\&sxs rf=ALeKk00JSw1X772tFzHKiKLWqIscMJS9Kg:1611411901970\&source=lnms\&tbm=isch\&sa=X\&v ed=2ahUKEwiWuIOQobLuAhUaQzABHZ6vBsMQ_AUoAXoECBUQAw\&biw=1242\&bih=597\#img rc=3wdk_PEHeRgy5M.

114.Gardenia. (2021). Ocimum sanctum (Holy Basil). [Image]. Retrieved from: https://www.google.com/search?q=Ocimum+tenuiflorum\&tbm=isch\&ved=2ahUKEwjpyur_nrLuAhWwc TABHXqaDOoQ2cCegQIABAA\&oq=Ocimum+tenuiflorum\&gs_lcp=CgNpbWcQAzICCAAyAggAMgIIADICCAAyAgg AMgIIADICCAAyBAgAEB4yBggAEAUQHjIECAAQGDoECAAQQzoHCCMQ6gIQJ1Cr0g5YxcOYKbtDmgBcAB4BIAByAWIAdMKkgEHMC41LjYtMZgBAKABAaoBC2d3cy13aXotaW1nsAEKw 
AEB\&sclient=img\&ei=gy8MYKn9B7DjwbkP-

rSy0A4\&rlz=1C1EJFC_enCA803CA803\#imgrc=_0g25kB2jFcEjM.

115. Gbolade, A. A. \& Lockwood, G. B. (2008). Toxicity of Ocimum sanctum L. essential oil to Ades aegypti larvae and its chemical composition. Journal of Essential Oil research. 11: 148-153. Journal of Pharmacognosy and Phytochemistry; 6(2): 261-264. Retrieved from: http://dx.doi.org/10.1080/10412905.2005.9699025.

116. Geiger, M. \& Meighan, C. W. (1976). As the Padres Saw Them: California Indian Life and Customs as Reported by the Franciscan Missionaries 1813-1885. Santa Barbara, CA: Santa Barbara Mission Archive Library.

117. Ghonmode, W. N.; Balsaraf, O. D.; Tambe, V. H. et al. (2013). Comparison of antibacterial efficiency of neem leaf extracts, grape seed extracts and 3\% sodium hypochlorite against E. faecalis-An in vitro study. J. Int. Oral Health. 5 (6). pg. 61-66.

118. Ghosh, A., Chowdhury, N. \& Chandra, G. (2012). Plant extracts as potential mosquito larvicides. Indian J Med Res.; 135(5):581-98.

119. Giovannini, P.; Howes, M-J. R.; \& Edward, S. (2016). Medicinal Plants used in traditional management of diabetes and its sequelae in Central America: A review. Journal of Ethnopharmacology. 184: 58-71. doi: 10.1016/j.jep.2016.02.032. Retrieved from: https://www.researchgate.net/publication/337649086_Medicinal_Plants_the_Medical_Food_and_Nutriti onal_Biochemistry_and_Uses/link/5e5805b44585152ce8f491d9/download.

120. Govere, J.; Durrheim, D. N.; Baker, L.; Hunt, R. \& Cotezee, M. (2000). Efficacy of three insect repellents against the malaria vector Anopheles arabiensis. Med. Vet. Entomol, 14. pg. 441-444. Journal of Molecules, 20, 7438-7453.

121. Groombridge, B. \& Jenkins, M. D. (2002). World Atlas of Biodiversity: Earth's Living Resources in the 21st Century. Berkley, CA: University of California Press.

122. Gruyter, D. (2018). $\alpha$-Terpineol, a natural monoterpene: A review of its biological properties. Retrieved from: https://www.degruyter.com/document/doi/10.1515/chem-20180040/html\#: :text=In\%20addition\%2C\%20\%CE\%B1\%2Dterpineol\%20attracts,and\%20also\%20has\%20i nsecticidal\%20properties.

123. Gunaherath, K. (2014). Plant Steroids: Occurrence, Biological Significance and their Analysis. Retrieved from: https://www.researchgate.net/publication/278310754_Plant_Steroids_Occurrence_Biological_Significan ce_and_their_Analysis.

124. Gunawardena, G. (2020). Reducing Sugar. Retrieved from: https://chem.libretexts.org/Ancillary_Materials/Reference/Organic_Chemistry_Glossary/Reducing_Suga r.

125.Guyana Chronicle. (2013). The Amazing Neem. Retrieved from: http://www.guyanachronicle.com/2013/04/24/lets-talk-herbs-the-amazing-neem/.

126. Habib, M. R. \& Karim, M. R. (2009). Antimicrobial and Cytotoxic Activity of Di-(2-ethylhexyl) Phthalate and Anhydrosophoradiol-3-acetate Isolated from Calotropis gigantea (Linn.) Flower. Retrieved from: https://www.ncbi.nlm.nih.gov/pmc/articles/PMC3749452/.

127. Habluetzel, A.; Pinto, B.; Tapanelli, S. et al. (2019). Effect of Azadirachta indica seed kernel extracts on early erythrocytic schizogony of Plasmodium berghei and pro-inflammatory response in inbred mice. Mara J. 18 (1): 35 .

128. Halabi, M. F. \& Sheikh, B. Y. (2014). Anti-proliferative effect and phytochemical analysis of Cymbopogon citratus extract. Biomed. Res. Int. 8 (2014). Scientific African Vol. 6. (2019).

129. Halver, J. E. (2020). Proteins and Amino Acids. Retrieved from: http://www.fao.org/3/x5738e/x5738e04.htm. 
130.Hamburger, M. and Hostettmann, K. (1991). Bioactivity in plants: the link between phytochemistry and medicine. Phytochemistry 30: 3864- 3874. Retrieved from: http://www.phytopharmajournal.com/Vol6_Issue6_08.pdf.

131. Hamid, S. K.; Al-Dubayana, A. H.; Youssef, K. A. et al. (2019). In vitro assessment of the antifungal effects of neem powder added polymethyl methacrylate denture base material. J. Chin Exp. Dent. 11 (2). pg. 170-178.

132. Han, Y.; Sun, Z. \& Chen, W. (2019). Antimicrobial Susceptibility and Antibacterial Mechanism of Limonene against Listeria monocytogenes. Retrieved from: https://www.ncbi.nlm.nih.gov/pmc/articles/PMC6982812/\#: :text=Limonene\%20has\%20broad\%20appl ication\%20prospects,as\%20fungal\%20activity\%20\%5B11\%5D.

133.Hariono, M.; Choi, S.; Roslim, R.; Nawi, M.; Tan, M.; Kamarulzaman, E. et al. (2019). Thioguaninebased DENV-2 NS2B/ NS3 protease inhibitors: Virtual screening, synthesis, biological evaluation and molecular modelling. PLOS ONE. 14 (1): e0210869.

134. Harrison, P. (1998). Herbal medicine takes roots in Germany. Canadian Medical Association Journal 10: 637-639. Retrieved from: http://www.phytopharmajournal.com/Vol6_Issue6_08.pdf.

135. Hartatie, E. S. et al. (2019). Bioactive Compounds of Lemon Grass (Cymbopogon citratus) essential oil from different part of the plant and distillation methods as natural antioxidant in broiler meat. IOP Conference Series: Material Science and Engineering. 532. 012018. Pg. 4. Retrieved from: http://doi:10.1088/1757-899X/532/1/012018.

136. Herbal Treatment. (2020). Importance of Herbal Medicine. Retrieved from: http://www.herbtreatment.com/importance-of-herbal-

medicine/page1.html\#: :text=Research\%20has\%20shown\%20that\%20over,a\%20guide\%20to\%20help\%2 Othem.

137. Hirpa, E. (2017). Review on swine flu and status on swine flu in Ethiopia. International Journal of Vaccines \& Vaccination. 4 (2). pg. 22-27.

138. Hossain, M. A.; Shah, M. D. \& Sakari, G. (2011). Gas chromatograph-mass spectrometry analysis of various organic extracts of Merremiaborneensis from Sabah. Asian Pacific Journal of Tropical Medicine. 4(8), pg. 637-641. Journal of Scientific Research, Vol. 64, 2020.

139. Hu, Q.; Sun, W.; Wang, C. et al. (2016). Recent advances of cocktail chemotherapy by combination drug delivery systems. Advanced Drug Delivery Reviews. 98. pg. 19-34.

140. Hussain, F.; Khurshid, M.; Masood, R. et al. (2017). Developing antimicrobial calcium alginate fibers from neem and papaya leaves extract. Journal of Wound Care. 26 (12). pg. 778-783.

141. Ibrahim, S. R. M. \& Mohamed, G. A. (2016). Naturally occurring naphthalene: chemistry, biosynthesis, structural elucidation, and biological activities. Retrieved from: https://link.springer.com/article/10.1007/s11101-015-9413-

5\#: :text=Naphthalene $\% 20$ derivatives $\% 20$ displayed $\% 20 \mathrm{a} \% 20$ wide, $\% 2 \mathrm{C} \% 20$ and $\% 20$ anti $\% 2$ Dplatelet $\%$ 20aggregation.

142. International Scholarly Research Notices. (2013). Antinociceptive Activity and Redox Profile of the Monoterpenes (+)-Camphene, p-Cymene, and Geranyl Acetate in Experimental Models. Retrieved from: https://www.hindawi.com/journals/isrn/2013/459530/.

143. Irshad, S.; Butt, M. \& Younus, H. (2011). In-vitro Antibacterial activity of two medicinal plant (Azadirachta indica) and Peppermint. Int. Res. J. Pharma. 1 (1).pg. 9-14.

144. Isman, M. B. (2006). Botanical insecticides, deterrents, and repellents in modern agriculture and an increasingly regulated world. Annu Rev Entomol.; 51:45-66. doi: 10.1146/annurev.ento.51.110104.151146.

145. IUCN Species Survival Commission Medicinal Plant Special Group. (2007). "Why Conserve and Manage Medicinal Plants?”. Retrieved from: www.iucn.org/themes/ssc/sgs/mpsg/main/Why.html. 
146. Ivanescu, B.; Miron, A. \& Corciova, A. (2015). Sesquiterpene Lactones from Artemisia Genus: Biological Activities and Methods of Analysis. Retrieved from: https://www.hindawi.com/journals/jamc/2015/247685/

147. Jeong, M. R.; Park, B. P.; Kim, D. H.; Jang, Y. S. Jeong, H. S. \& Choi, S. H. (2009). Essential oil prepared from Cymbopogon citratus exerted an antimicrobial activity against plant pathogenic and medicinal microorganism. Microbiology, 37. pg. 48-52. Journal of Molecules, 20, 7438-7453.

148. Jones, I. W.; Denholm, A. A.; Ley, S. V.; Lovell, H.; Wood, A. \& Siden, R. E. (1994). Sexual development of malaria parasite is inhibited in vitro by the neem extract azadirachtin, and its semisynthetic analogues. FEMS Microbial Lett. 120(3): 267-273. Pharmacognosy Journal: Review Article, 2019.

149. Jones, W.B. (1998). Alternative medicine-learning from the past examining the present advancing to the future. Journal of American Medical Association 280: 1616-1618. Retrieved from: http://www.phytopharmajournal.com/Vol6_Issue6_08.pdf.

150. Journal of Complementary and Alternative Medicinal Research. (2019). Review Article: The Potential Pharmacological and Medicinal Properties of Neem (Azadirachta indica A. Juss) in the drug development of Phytomedicine. 7(1): 1-18.

151. Kabeh, J. B. (2007). Mini review exploiting neem (Azadirachta indica) resources for improving the quality of life in Taraba State, Nigeria. Int. J. Agri Biol. 9 (3). pg. 530-532.

152. Kale, P. B.; Kothekar, M. A.; Tayade, H. P.; Jaju, J. B. \& Meteenuddin, M. (2003). Effect of aqueous extract of Azadirachta indica leaves on hepatotoxicity induced by antitubercular drugs in rats. Indian J. Pharmacol. 35. pg. 177-180.

153. Kamatou, G. P. P. \& Viljoen, A. M. (2008). Linalool - A Review of a Biologically Active Compound of Commercial Importance. Retrieved from: https://journals.sagepub.com/doi/pdf/10.1177/1934578X0800300727\#: :text=Linalool\%20and\%20linal ool\%2Drich\%20essential,on\%20the\%20central\%20nervous\%20system.

154. Kandheri, A. D.; Mukherjee, A. A. \& Bodhankar, S. L. (2017). Neuroprotective effect of Azadirachta indica standarzied extract in partial sciatic nerve injury in rats: Evidence from Anti-inflammatory, antioxidant and anti-apoptotic studies. EXCLI J. 16. pg. 546-565.

155. Kashyap, C.; Ranjeet, K. Vikrant, A. \& Vipin, K. (2011). Therapeutic potency of Ocimum tenuiflorum Guerke-A Review. Global Journal of Pharmacology. 5(3): 191-200. Journal of Pharmacognosy and Phytochemistry; 6(2): 261-264.

156. Kaur, G.; Alam, M. S. \& Athar, M. (2004). Nimbidin suppresses functions of macrophages and neutrophils: relevance to its anti-inflammatory mechanisms. Retrieved from: https://pubmed.ncbi.nlm.nih.gov/15174005/\#: :text=Nimbidin\%20is\%20a\%20mixture\%20of,potent\%2 0antiinflammatory\%20and\%20antiarthritic\%20activities.\&text=Thus\%20nimbidin $\% 20 \mathrm{can} \% 20 \mathrm{be} \% 20 \mathrm{va}$ luable\%20in\%20treating\%20inflammation\%2Finflammatory\%20diseases.

157. Kazemi, M. \& Rostami, H. (2015). Chemical composition, antimicrobial and antioxidant activities of the essential oil of Psammogeton canescens. Retrieved from: https://pubmed.ncbi.nlm.nih.gov/25154367/\#: :text=\%CE\%B2\%2DBisabolene\%20exhibited\%20strong \%20antioxidant, \%C2\%B1\%200.8\%20\%CE\%BCg\%2FmL).\&text=In\%20conclusion $\% 2 \mathrm{C} \% 20$ these $\% 20$ results\%20support,antioxidant\%20properties\%20and\%20antimicrobial\%20activity.

158. Kele, M. \& Tepe, B. (2008). Chemical composition, antioxidant and antimicrobial properties of the essential oils of three Salvia species from Turkish flora. Retrieved from: https://pubmed.ncbi.nlm.nih.gov/17936619/.

159. Kepe, T. (2004). Land restitution and biodiversity conservation in South Africa: The case of Mkambati, eastern cape province. Can. J. Afr. Stud, 38. pg. 688-704. Journal of Molecules, 20, 7438-7453.

160. Khan, A.; Ahamad, A. Akhtar, F.; Yousuf, K. Xess, I.; Khan, L. A et al. (2010). Ocimum sanctum essential oil and its active principles exert their antifungal activity by disrupting ergosterol biosynthesis 
and membrane integrity. Research in microbiology. 161: 816-823. Journal of Pharmacognosy and Phytochemistry; 6(2): 261-264. Retrieved from: http://dx.doi.org/10.1080/10412905.2005.9699025.

161. Kicel, A.; Kurowska, A. \& Kalemba, D. (2005). Composition of Essential Oil of Ocimum sanctum L. grown in Poland during vegetation. Journal of Essential Oil research. 17: 217-219. Journal of Pharmacognosy and Phytochemistry; 6(2): 261-264. Retrieved from: http://dx.doi.org/10.1080/10412905.2005.9699025.

162. Kochhar, A.; Sharma, N. \& Sachdeva, R. (2009). Effect of Supplementation of Tulsi (Ocimum sanctum) and Neem (Azadirachta indica) Leaf Powder on Diabetic Symptoms, Anthropometric Parameters and Blood Pressure of Non-Insulin Dependent, Male Diabetics. Ethno. Med. 3 (1). pg. 5-9.

163. Kokate, C.; Purohit, A. \& Gokhale, S. B. (2010). Pharmacognosy. NiraliPrakashan, Maharasnhtra, India. Journal of Scientific Research, Vol. 64, 2020.

164. Kothari, s. K.; Bhattacharya, A. K.; Ramesh, S.; Garg, S. N. \& Khanuja, S. P. S. (2005). Volatile constituents in oils from different plant parts of methyl eugenol-rich Ocimum tenuiflorum L. $f$. (Syn. O. sanctum L.) grown in South India. Journal of Essential Oil research. 17: 656-658. Journal of Pharmacognosy and Phytochemistry; 6(2): 261-264. Retrieved from: http://dx.doi.org/10.1080/10412905.2005.9699025.

165. Koziol, A.; Stryjewska, A.; Librowski, T. \& Salat, K. (2014). An Overview of the Pharmacological Properties and Potential Applications of Natural Monoterpenes. Retrieved from: https://www.researchgate.net/publication/268880152_An_Overview_of_the_Pharmacological_Propertie s_and_Potential_Applications_of_Natural_Monoterpenes\#: :text=Studies\%20have\%20shown\%20that\% 20both,inflammatory\%2C\%20antihistaminic\%20and\%20anti\%2Dspasmodic.

166. Krebihel, A. (2018). What are Tannins, Really? Retrieved from: https://www.winemag.com/2018/09/11/tannins-wine-guide/.

167. Kumar, P.; Mishra, S.; Malik, A. \& Satya, S. (2013). Housefly (Musca domescia L.) control potential of Cymbopogon citratus Stapf. (Polaes: Poaceae) essential oil and monoterpenes (citral and 1, 8-cineole), Parasitol. Res. 112 (2013). pg. 69-76. Scientific African Vol. 6. (2019).

168. Kumar, S. \& Pandey, A. K. (2013). Chemical and Biological Activities of Flavonoids: An Overview, The Scientific World Journal. Article ID 162750. Retrieved from: http://dx.doi.org/10.1155/2013/162750.

169. La Cruz-Lovera, D.; Perea-Morento, A. J.; La Cruz-Fernendez, D.; Alvarez-Bermejo, J. A; ManzanoAgugliaro, F. (2017). Worldwide Research on energy efficiency and sustainability in public buildings. Sustainability $1294 . \quad$ [CrossRef]. Retrieved from: https://www.researchgate.net/publication/337649086_Medicinal_Plants_the_Medical_Food_and_Nutriti onal_Biochemistry_and_Uses/link/5e5805b44585152ce8f491d9/download.

170. Laurance, J. (2005). Why an Exotic Fruit is the World's Only Weapon Against Bird Flu? Retrieved from: news.independent.co.uk/uk/health medical/article319716.ece.

171. Leafy. (2021). Sabinene. Retrieved from: https://www.leafly.com/learn/cannabis-glossary/sabinene.

172. Lee, H. J.; Jeong, H. S.; Kim, D. J.; Noh, Y. H.; Yuk, D. Y. \& Hong, J. T. (2008). Inhibitory effect of citral on NO production by suppression of iNOS expression and NF-kappa B activation in RAW 264.7. cells. Archives of Pharmacal Research. 31. pg. 242-349.

173. Leite, B. L.; Souza, T. T.; Antoniolli, A. R.; Guimaraes, A. G.; Rosana, S. Q.; Jullyana, S. S.; Bonjardim, L. R.; Alves, P. B.; Arie, F. B.; Marco, A. A. et al. (2011). Volatile constituents and behavioral change induced by Cymbopogon winterianus leaf essential oil in rodents. Afr. J. Biotechnol, 10. pg. 8312-8319. Journal of Molecules, 20, 7438-7453.

174. Libre Text. (2019). Catechol. Retrieved from: https://chem.libretexts.org/Under_Construction/Stalled_Project_(Not_under_Active_Development)/Wal ker/Chemicals/Substance_C/Catechol.

175. Libre Text. (2020). Synthetic Antimicrobial Drugs. Retrieved from: https://bio.libretexts.org/Bookshelves/Microbiology/Book\%3A_Microbiology_(Boundless)/13\%3A_Ant 
imicrobial_Drugs/13.3\%3A_Commonly_Used_Antimicrobial_Drugs/13.3A\%3A_Synthetic_Antimicrob ial_Drugs.

176. Libre

Text.

(2020).

Terpenoids.

Retrieved

from:

https://chem.libretexts.org/Courses/Athabasca_University/Chemistry_360\%3A_Organic_Chemistry_II/ Chapter_27\%3A_Biomolecules_-_Lipids/27.05_Terpenoids.

177. Lochnit, G.; Dennis, R. D.; Ulmer, A. J. \& Geyer, R. (1997). Structural Elucidation and Monokineinducing Activity of Two Biologically Active Zwitterionic Glycosphingolipids Derived from the Porcine Parasitic Nematode Ascaris suum. Retrieved from: https://www.jbc.org/article/S0021-9258(18)386058/pdf.

178. López-Lázaro, M. (2009). Distribution and biological activities of the flavonoid luteolin. Retrieved from:

https://pubmed.ncbi.nlm.nih.gov/19149659/\#: :text=The\%20ability\%20of\%20luteolin\%20to,cancer\%2 0chemopreventive\%20and\%20chemotherapeutic\%20potential.

179. Machado, M. I. L.; Silva, M. G. V.; Matos, F. J. A.; Craveiro, A. A. \& Alencar, J. W. (1999). Volatile constituents from leaves and inflorescence oil of Ocimum tenuiflorum L. f. (Syn. O. sanctum L.) grown in Northeastern Brazil. Journal of Essential Oil research. 11: 324-326. Journal of Pharmacognosy and Phytochemistry; 6(2): 261-264. Retrieved from: http://dx.doi.org/10.1080/10412905.2005.9699025.

180. Mafou-Sonhafouo, V.; Kana, J. R. \& Nguepi-Dongmo, K. (2019). Effects of graded levels of Azadirachta indica seed oil on growth performance and biochemical profiles of broiler chickens. Vet. Med. Sci. 5 (3).pg. $442-450$.

181. Mahboubi, M. \& Kazempour, N. (2012). Biochemical activities of Iranian Cymbopogon olivieri (Boiss) Bor. essential oil. Indian J. Pharm. Sci. 74.pg. 356-360. Journal of Molecules, 20, 7438-7453,

182. Mahmoud, D. A.; Hassanein, N. M.; Youssef, K. A. et al. (2011). Antifungal activity of different neem leaf extracts and the nimonol against some important human pathogens. Brazilian Journal of Microbiology. 43. pg. 1007-1016.

183. Mancianti, F. (2019). Special Issue "Biological Activities of Essential Oils". Retrieved from: https://www.mdpi.com/journal/molecules/special_issues/biological_essential_oils.

184. Mandal, S.; Das, D. N.; Kamala, D.; Ray, K.; Roy, G. \& Chaudhari, S. B. (1993). Sahana-Ocimum sanctum Linn-A study of gastric ulceration and gastric secretion in rats. Indian J. Physiol. Pharmacol. 37. pg. 91-97.

185. Manogaran, S.; Sulochana, N. \& Kavimami, S. (1998). Anti-inflammatory and anti-microbial activities of the root, bark and leaves of A. indica. Ancient Science of Life. 18 (1): 29-34.

186. Marchese, A.; Arciola, C. R.; Barbieri, R.; Silva, A. S.; Navabi, S. F.; Sokeng, A. J. T.; Izadi, M.; Jafari, N. J.; Suntar, I.; Daglia, M. \& Navabi, S. M. (2017). Update on Monoterpenes as Antimicrobial Agents: A Particular Focus on p-Cymene. Retrieved from: https://pubmed.ncbi.nlm.nih.gov/28809799/\#: :text=p\%2DCymene\%20\%5B1\%2Dmethyl,anxiolytic\%2 C\%20anticancer\%20and\%20antimicrobial\%20effects.

187. Marinelli, J. (2005). Plants: The Ultimate Visual to Plants and Flowers of the World. New York: DK Publishing, Inc.

188. Med Broadcast. (2021). Tricyclene. Retrieved from: https://www.medbroadcast.com/drug/getdrug/tricyclen.

189. Medline Plus. (2020). Herbal Medicine. Retrieved from: https://medlineplus.gov/herbalmedicine.html.

190. Milliken, W. (2015). Medicinal knowledge in the Amazon. Kew Gardens. Retrieved from: https://www.researchgate.net/publication/337649086_Medicinal_Plants_the_Medical_Food_and_Nutriti onal_Biochemistry_and_Uses/link/5e5805b44585152ce8f491d9/download.

191. Mirghani, M. E. S.; Liyana, L. \& Parveen, J. (2012). Bioactivity analysis of Lemongrass (Cymbopogon citratus) essential oil. International Food Research Journal. 19. pg. 569-572. 
192. Mittermeier, R. A., Gil, R. P., Hoffman, M., Pilgrim, J., Brooks, T., Mittermeier, C. G., Lamoreux, J. and Fonseca, G. A. B. (2005). Hotspots revisited: Earth's biologically richest and most endangered terrestrial ecoregions. Pp 392. Boston: University of Chicago Press. Retrieved from: http://www.phytopharmajournal.com/Vol6_Issue6_08.pdf.

193. Mlala, S.; Oyedeji, A. O.; Gondwe, M. \& Oyedeji, O. O. (2019). Ursolic Acid and Its Derivatives as Bioactive Agents. Retrieved from: https://www.ncbi.nlm.nih.gov/pmc/articles/PMC6695944/\#: :text=One\%20of\%20such\%20PT\%20is,sol ubility\%20limits\%20its\%20clinical\%20application.

194. Moga, M.; Balan, A.; Anastasiu, C. et al. (2016). An Overview on the Anticancer Activity of Azadirachta indica (Neem) in Gynecological Cancers. International Journal of Molecular Sciences. 19 (12). pg. 3898.

195. Mokgolodi, N. C.; Hu, Y. \& Shi, L. (2011). Ziziphus mucronata: an underutilized traditional medicinal plant in Africa. Retrieved from: https://link.springer.com/article/10.1007/s11632-011-0309-1.

196. Monein, A. A. E. (2014). Azadirachta indica attenuates cisplatin-induced neurotoxicity in rats. Indian J. Pharmacol. 46. pg. 316-321.

197. Monein, A. A. E.; Oatman, M. S. \& Aref, A. S. (2014). Azadirachta indica attenuates cisplatin-induced neurotoxicity and oxidative stress. Biomed. Res. Int. 2014: 347131.

198. Moore-Neibel, K.; Gerber, C.; Patel, J.; Friedman, M. \& Ravishankar, S. (2012). Antimicrobial Activity of Lemon Grass Oil against Salmonella enterica on organic leafy greens. J. Appl. Microbiol. 112 (2012); pg. 485-492. Scientific African Vol. 6. (2019).

199. Mordue, L. A. J.; Davison, G.; McKinlay, R. G. \& Hughes, J. (1995). Observation of Azadirachtin for the management of cabbage caterpillar infestation in the field. BCPC. Symp. Proceed. 63. pg. 371-378.

200. Mordue, L. A. J.; Zounos, A.; Wickramananda, I. R. \& Allan, E. J. (1995). Neem tissue culture and the production of insect antifeedant and growth regulatory compounds. BCPC. Symp. Proceed. 63. pg. 187194.

201. Mount, T. (2015). 9 weird medieval medicines. British Broadcasting Corporation. Retrieved from: https://www.researchgate.net/publication/337649086_Medicinal_Plants_the_Medical_Food_and_Nutriti onal_Biochemistry_and_Uses/link/5e5805b44585152ce8f491d9/download.

202. Naidoo, N.; Thangaraj, K. \& Baijnath, H. (2008). CHEMICAL COMPOSITION AND BIOLOGICAL ACTIVITY OF THE ESSENTIAL OIL FROM CYMBOPOGON NARDUS (L.) RENDLE. Retrieved from: https://journals.athmsi.org/index.php/ajtcam/article/view/779.

203. Nakamura, C. V.; Ishida, K.; Faccin, L. C.; Filho, B. P. D.; Cortez, D. A. G.; Rozental, S.; De Souza, W. \& Ueda-Nakamura, T. (2004). In Vitro activity of essential oil from Ocimum tenuiflorum L. against four Candida species. Research in Microbiology. 155 (7). pg. 579-586.

204. Nanon, A.; Suksombar, W.; Beauchemin, K. \& Yang, W. (2014). Assessment of lemon grass oil supplementation on a dairy diet on in vitroruminal fermentation characteristic using the rumen simulation technique. Can. J. Amin. Sci. 94 (2014). pg. 731-736. Scientific African Vol. 6. (2019).

205. Nayak, A.; Ranganathan, N.; Sowmya, K. B.; Kishore, B. \& Kudalkar, M. (2011). Evaluation of antibacterial and anticadidal efficacy of aqueous and alcoholic effect of neem (Azadirachta indica): An In Vitro Study. Int. J. Res. Ayurveda Pharm. 2. pg. 230-235..

206. Neelmani, K. M. \& Kumar, N. (2016). Effect of neem (Azadirachta indica) on peptic ulcer in albino rats. International Journal of Advanced Research in Science and Engineering. 5. 8.

207. Nguefack, J.; Tamgue, O.; Dongmo, J. B. L.; Dakolea, C. D.; Leth, V.; Vismer, H. F.; Zollo, P. H. A. \& Nguefack, A. E. (2012). Synergistic action, between factions of essential oils from Cymbopogon citratus, Ocimum gratissimum and Thymus vulgaris against Penicillium expansum. Food Control. 23. pg. 377 383.

208. Noor, S.; Latip, H. Lakim, M. Z.; Syahirah, A. \& Bakar, A. (2012). The potential of Citronella Grass, Cymbopogon nardus as Biopesticide Against Plutella xylostella Faculty of Plantation and 
Agrotechnology, University Technology MARA 40450 Shah Alam. In Proceedings of the UMT $11^{\text {th }}$ International Annual Symposium on Sustainability Science and Management. Kuala Terengganu, Malysia. pg. 190-193. Journal of Molecules, 20, 7438-7453.

209. Noriega, P.; Guerrini, A.; Sacchetti, G.; Grandini, A.; Ankuash, E. \& Manfredini, S. (2019). Chemical Composition and Biological Activity of Five Essential Oils from the Ecuadorian Amazon Rain Forest. Retrieved from: https://www.mdpi.com/1420-3049/24/8/1637/review_report.

210. Obeng-Ofori, D.; Reichmunt, C. H.; Bekele, J. \& Hassanali, A. (2009). Biological activity of 1,8 cineole, a major component of essential oil of Ocimum kenyense (Ayobangira) against stored product beetles. Retrieved from: https://onlinelibrary.wiley.com/doi/abs/10.1111/j.1439-0418.1997.tb01399.x.

211. Ocimum sanctum: The India Home Remedy. In Current Medical Scene. (1992). Edited and Published by Rajeshwari, S., Cipla Ltd. Bombay Central, Bombay.

212. Ofusori, D. A.; Falana, B. A.; Ofusori, A. E. \& Caxton-Martins, E. A. (2010). Regenerative Potential of Aqueous Extract of Neem Azadirachta indica on the Stomach and Ilium Following Ethanol-Induced Mucosa Lesion in Adult Wistar Rats. Gastroenterology. 3 (2). pg. 86-90.

213. Ogbuewu, I.; Odoenmenam, V.; Obikaonu, H.; etal. (2011). The growing Importance of Neem (Azadirachta indica A. Juss) in Agriculture, Industry, Medicine and Environmental: A Review. Research Journal of Medicinal Plant: 5 (3): 230-254.

214. Opeyemi, A.; Oyedeji, O.; Rungqu, P.; Nkeh-Chungag, B. \& Oyedeji, A. (2015). Review: Cymbopogon Species; Ethnopharmacology, Phytochemistry and the Pharmacological Importance. Journal of Molecules, 20, 7438-7453.

215. Orji, J. O.; Nwuzo, A. C.; Ejikeugwu, P. C.; Ugbo, E. N.; Moses, I. B.; Nwakaeze, E. A. et al. (2015). Antifungal activity of leaves extracts of Ocimum sanctum Linn. Advances in in Pharmacology and Toxicology. 11 (3).pg. 102-107.

216. Orji, J. O.; Nwuzo, A. C.; Ejikeugwu, P. C.; Ugbo, E. N.; Moses, I. B.; Nwakaeze, E. A. et al. (2015). Antifungal activity of leaves extracts of Ocimum sanctum and Gongronema latifolium leaves on Colletotrichum species isolated from spoilt tomatoes. Internal Journal of Pharmaceutical Science. 11 (3). pg. 42-45.

217. Osunwoke, E. A.; Olotu, E. J.; Allison, T. A. \& Onyekwere, J. C. (2013). The Wound healing effect of aqueous leave extract of Azadirachta indica on Wistar Rats. J. Nat. Sci. Res. 3.pg. 181-186.

218. Packia, L. N. C. J.; Sowmia, N.; Veveka, S.; Raja, B. J. \& Jeeva, S. (2012). The inhibiting effect of Azadirachta indica against dental pathogens. Asia J. Plant Sci. Res. 2. pg. 6-10.

219. Padalia, R. C.; Verma, R. S. Chanotiya, C. S. \& Yadav, A. (2011). A Chemical Fingerprinting of the fragment volatiles of nineteen Indian cultivar of Cymbopogon Spreng (Poaceae). Rec. Nat. Prod, 5. Pg. 290-299. Journal of Molecules, 20, 7438-7453.

220. Paddock, C. (2016). Pancreatic cancer may be treatable with tree extract. Retrieved from: https://www.medicalnewstoday.com/articles/306462.

221. Pai, M. R.; Acharya, L. D. \& Udupa, N. (2004). Evaluation of Anti-plaque activity of Azadirachta indica leaf extract gel-A 6-week clinical study. J. Ethonopharmacol. 90. pg. 99-103.

222. Pandey, A. B. P. (1990). Economic Botany (Published by Chand and Company Ltd., Ramnagar, New Delhi), pg. 294.

223. Pandey, G.; Verma, K. K. \& Singh, M. (2014). Evaluation of Phytochemical, Antibacterial and Free Radical Scavenging Properties of Azadirachta indica (Neem) Leaf. International Journal of Pharmacy and Pharmaceutical Sciences, Vol. 6, 2014.

224. Parinitha, M.; Srinivasa, B. H.; Shivanna, M. B. (2005). Medicinal plant wealth of local communities in some villages in Shimoga district of Karnataka. India J Ethonopharmacol. 98: 307-312.

225. Partibha, D.; Nagid \& Laxmi, S. (2005). Anti-tissue Activity. Indian J. Physiol. Pharmacol. 42 (2). pg. 243-245. 
226. Patil, P.; Patil, S.; Mane, A. et al. (2013). Anti-diabetic Activity of Alcoholic Extract of Neem (Azadirachta indica) Root Bark. National Journal of Physiology, Pharmacy and Pharmacology. 3. pg. 142-146.

227. Patil, S.; Venkataraghavan, K.; Anantharaj, A. \& Patil, S. (2010). Comparison of two commercially available toothpaste on the salivary Streptococcus mutans count in urban pre school-An In Vivo Study. International Dentistry SA. 12.pg. 72-80.

228. Paul, R.; Prasad, M. \& Sah, N. K. (2011). Anticancer biology of Azadirachta indica L (neem): a mini review. Cancer Biology and Therapy. 12: 467-476 pg.

229. Paula, A. R.; Riberio, A.; Alves-Lemos, F. J. et al. (2019). Neem oil increases the persistence of the entomopathogenic fungus Metarhizium anisopliae for the control of Aedes aegypti (Diptera: Culicidae) larvae. Parasit vector. 12. pg. 163.

230. Paula, J. T.; Paviani, L. C.; Foglio, M.; Sousa, I. M.; Duarte, G. H.; Jorge, M.; Eberlin, M.; Eberlin, M. \& Cabral, F. (2014). Extraction of anthocyanins and luteolin for Arrabida eachica by sequential extraction infixed bed using Supercritical $\mathrm{CO}_{2}$, ethanol and water as solvents. J. Supercrit. Fluids 86 (2014); pg. 100-107. Scientific African Vol. 6. (2019).

231. Peer, P. A.; Trivedi, P. C.; Nigade, P. B.; Ghaisas, M. M. \& Deshpande, A. D. (2008). Cardioprotective effect of Azadirachta indica A. juss on isoprenaline induced myocardial infraction in rats. Int. J. Cardiol. 121. pg. 123-126.

232. Pei, K.; Ou, J.; Huang, J. \& Ou, S. (2015). p-Coumaric acid and its conjugates: Dietary sources, pharmacokinetic properties and biological activities. Retrieved from: https://www.researchgate.net/publication/287958863_p-

Coumaric_acid_and_its_conjugates_Dietary_sources_pharmacokinetic_properties_and_biological_activ ities\#: :text=Their\%20biological\%20activities\%2C\%20including\%20antioxidant,hyperlipaemia\%20and \%20gout\%20are\%20compared.

233. Pezzuto, J. M. (1997). "Plant-derived anticancer agents”. Biochemical Pharmacology. 53 (2): 121-133. doi:10.1016/S0006-2952(96)00654-5. Retrieved

from: https://www.researchgate.net/publication/337649086_Medicinal_Plants_the_Medical_Food_and_Nutriti onal_Biochemistry_and_Uses/link/5e5805b44585152ce8f491d9/download.

234. Physiotherapy Research. (2009). O. santum induces apoptosis in A549 lung cancer cells and suppresses the in vivo growth in Lewis carcinoma cells. 23 (10). pg. 1385-1391.

235. Phytochemicals. (2021). Isorhamnetin. Retrieved from: https://www.phytochemicals.info/phytochemicals/isorhamnetin.php.

236. Polaquini, S. R.; Svidzinski, T. I.; Kemmelmeir, C. \& Gasparetto, A. (2006). Effect of Aqueous extract from neem to hydrophobicity, biofilm formation and adhesion in composite resin by Candida albicans. Arch Oral Biol. 51.pg. 482-490.

237. Prabuseenivasan, S.; Jayakumar, M. \& Ignacimuthu, S. (2006). Iin vitro antibacterial activity of some plant essential oils. BMC Complementary and Alternative Medicine. 6(1). pg. 1.

238. Prakash, P. \& Gupta, N. (2005). Therapeutic use of Ocimum sanctum Linn (Tulsi) with a note on eugenol and its pharmacological actions: A Short Review. Indian J. Physiol. Pharmacol. 49 (2). pg. 125 131.

239. Pratheeba, T.; Ragavendran, C. \& Natarajan, D. (2015). Larvicidal, pupicidal and adulticidal potential of Ocimum gratissimum plant leaf extracts against filariasis inducing vectors. International Journal of Mosquito Research. 2 (2). pg. 1-8.

240. Principe, P. P. (1991). Valuing the Biodiversity of Medical Plants. In Akeele, O.; Haywood, V.; and Synge, H. (eds), The conservation of medicinal plants, pp 139-156. Cambridge University Press, Cambridge. Retrieved from: https://www.researchgate.net/publication/270338632_Medicinal_Plants_in_Tropical_Homegardens/link/ 55b6146408aed621de030b84/download. 
https://pubchem.ncbi.nlm.nih.gov/compound/6-Methyl-5-hepten-2-

one\#: :text=Sulcatone $\% 20$ is $\% 20 \mathrm{a} \% 20$ heptenone $\% 20$ that,methyl\%20ketone $\% 20$ and $\% 20 \mathrm{a} \% 20$ heptenon e.

242. Pub

Chem.

(2021).

Ascorbic

Acid.

Retrieved

from:

https://pubchem.ncbi.nlm.nih.gov/compound/Ascorbic-acid.

243. Pub Chem. (2021). Astragalin. Retrieved from: https://pubchem.ncbi.nlm.nih.gov/compound/Astragalin.

244. Pub Chem. (2021). Citral. Retrieved from: https://pubchem.ncbi.nlm.nih.gov/compound/Citral.

245. Pub

Chem.

(2021).

Cynaroside.

Retrieved

from:

https://pubchem.ncbi.nlm.nih.gov/compound/Cynaroside.

246. Pub Chem. (2021). Myrene. Retrieved from: https://pubchem.ncbi.nlm.nih.gov/compound/Myrcene.

247. Pub Chem. (2021). Nimbin. Retrieved from: https://pubchem.ncbi.nlm.nih.gov/compound/Nimbin.

248. Pub Chem. (2021). Patchouli Alcohol. Retrieved from: https://pubchem.ncbi.nlm.nih.gov/compound/Patchouli-alcohol.

249. Pub Chem. (2021). Sugiol. Retrieved from: https://pubchem.ncbi.nlm.nih.gov/compound/Sugiol.

250. Pub Chem. (2021). $\quad \beta$-caryophyllene. Retrieved from: https://www.google.com/search?q=biological+activity+of+Caryophyllene+Oxide\&rlz=1C1EJFC_enCA 803CA803\&sxsrf=ALeKk00DYdykOb9MT_5flW2Fk7t3z9WAHg\%3A1619813662156\&ei=HmWMY KiHCYSe_QaEsbToAg\&oq=biological+activity+of+Caryophyllene+Oxide\&gs_lcp=Cgdnd3Mtd216EA MyBQghEKABOgcIIxCwAxAnOgcIABBHELADOgQIIxAnOgIIAFD4EFiGLWDOMmgCcAJ4AYA BnwSIAYERkgELMC4yLjQuMS4wLjGYAQCgAQGgAQKqAQdnd3Mtd216yAEJwAEB\&sclient=gw s-wiz\&ved=0ahUKEwiojr2P5KbwAhUET98KHYQYDS0Q4dUDCA4\&uact=5.

251. Rahim, S. M.; Taha, E. M.; Mubark, Z. M.; Aziz, S. S.; Simon, K. D. \& Mazlan, A. G. (2013). Cymbopogon citratus on hydrogen peroxide-induced oxidative stress in the reproductive system of male rat systems. Biol. Reproduct. Med. 59 (2013). pg. 329. Scientific African Vol. 6. (2019).

252. Rai, Y. (2002). Holy Basil: Tulsi (An Herb). Publications India Ltd.

253. Rana, P. K.; Kumar, P.; Singhal, V. K \& Rana, J. (2014). Uses of Local Plant Biodiversity among the Tribal Communities of Pangi Valley of District Chamba in Cold Desert Himalaya, India. Retrieved from: https://www.researchgate.net/figure/Percentage-of-plant-parts-used-for-medicinal-and-otherimportant-uses_fig2_261328673.

254. Rehman, J.; Dillow, J. M.; Carter, S. M.; Chou, J.; Lee, B. B. \& Maisel, A. S. (1999). Increased production of antigen-specific immunoglobins $G$ and $M$ following in vivo treatment with the medicinal plants Echinacea angustifolia and Hydrastis canadensis. Immunol. Lett. 68. pg. 391-396.

255. Research Gate. (2011). Synthesis, structural chemistry and antimicrobial activity of - borneol derivative. Retrieved from: https://www.researchgate.net/publication/225498849_Synthesis_structural_chemistry_and_antimicrobial _activity_of_--_borneol_derivative.

256. Research Gate. (2018). A review: Biological activity of myrtenal and some myrtenal-containing medicinal plant essential oils. Retrieved https://www.researchgate.net/publication/331224063_A_review_Biological_activity_of_myrtenal_and_s ome_myrtenal-containing_medicinal_plant_essential_oils.

257. Research Gate. (2021). Flavanol glycosides from Azadirachta Indica. L. Retrieved from: https://www.researchgate.net/figure/The-structures-of-identified-flavonol-glycosides-from-

AAzadirachta-indica-a-Melicitrin_fig2_327046504.

258. Rhanita, M.; Abdurahman, H.; Suliaman, Z.; Nour, A. \& Raj, S. T. (2014). Comparative study of lemon grass (Cymbopogon citratus) essential oil extracted by microwave-assisted hydrodistillation (MADH) and conventional hydrodistillation (HD) method. Int. J. Chem. Eng. Appl. 5 (2) (2014). pg. 104-108. Scientific African Vol. 6. (2019). 
259. Roy, A. \& Saraf, S. (2006). Limonoids: overview of significant bioactive triterpenes distributed in plants kingdom. Retrieved from: https://pubmed.ncbi.nlm.nih.gov/16462017/.

260. Rupani, R. \& Chavez, A. Medicinal plants with traditional uses: Ethnobotany in the Indian subcontinent. Clin Dermatology. 36 (3): 306-309.

261. Sadgir, P.; Nilosey, V.; Bhandari, R. \& Patil, B. R. (2010). Research Journal of Chemistry and Environment. 14 (3). pg. 46-50.

262. Saleem, M. (2009). Lupeol, A Novel Anti-inflammatory and Anti-cancer Dietary Triterpene. Retrieved from: https://www.ncbi.nlm.nih.gov/pmc/articles/PMC2764818/.

263. Salem, S.; Zayed, M. Z.; Ali, H. M. \& El-Kareem, M. S. M. (2016). Chemical composition, antioxidant and antibacterial activities of extracts from Schinus molle wood branch growing in Egypt. Retrieved from: https://jwoodscience.springeropen.com/articles/10.1007/s10086-016-1583-2.

264. Sathyamurthy, B. (2017). In vitro studies of Azadirachta indica L. in lung cancer a549 cell line. World Journal of Pharmacy and Pharmaceutical Sciences. pg. 1627-1640.

265. Scielo. (2009). Citral and carvone chemotypes from the essential oils of Colombian Lippia alba (Mill.) N.E. Brown: composition, cytotoxicity and antifungal activity. Retrieved from: https://www.scielo.br/scielo.php?script=sci_arttext\&pid=S0074-02762009000600010.

266. Science Direct. (2003). Isoborenol. Retrieved from: https://www.sciencedirect.com/topics/medicine-anddentistry/isoborneol.

267. Science Direct. (2013). Chemical composition and anticancer, anti-inflammatory, antioxidant and antimalarial activities of leaves essential oil of Cedrelopsis grevei-Guaiene. Retrieved from: https://www.sciencedirect.com/science/article/abs/pii/S0278691513001166.

268. Science Direct. (2015). Evaluation of mutagenic and antimicrobial properties of brown propolis essential oil from the Brazilian Cerrado biome. Retrieved from: https://www.sciencedirect.com/science/article/pii/S2214750015300858.

269. Science Direct. (2016). Quercetin. Retrieved from: https://www.sciencedirect.com/topics/neuroscience/quercetin.

270. Science Direct. (2017). Gedunin. Retrieved from: https://www.sciencedirect.com/topics/medicine-anddentistry/gedunin.

271. Science Direct. (2017). Linalool. Retrieved from: https://www.sciencedirect.com/topics/medicine-anddentistry/linalool.

272. Science Direct. (2018). Apigenin. Retrieved from: https://www.sciencedirect.com/topics/pharmacologytoxicology-and-pharmaceutical-science/apigenin.

273. Science Direct. (2021). Anthraquinones. Retrieved from: https://www.sciencedirect.com/topics/pharmacology-toxicology-and-pharmaceuticalscience/anthraquinones.

274. Science Direct. (2021). Azadirachtin. Retrieved from: https://www.sciencedirect.com/topics/agriculturaland-biological-sciences/azadirachtin.

275. Science Direct. (2021). Beta Elemene. Retrieved from: https://www.sciencedirect.com/topics/pharmacology-toxicology-and-pharmaceuticalscience/germacrene-d.

276. Science Direct. (2021). Carvacrol. Retrieved from: https://www.sciencedirect.com/topics/medicine-anddentistry/carvacrol.

277. Science Direct. (2021). Caryophyllene. Retrieved from: https://www.sciencedirect.com/topics/medicineand-dentistry/caryophyllene.

278. Science Direct. (2021). Citronella. Retrieved from: https://www.sciencedirect.com/topics/agriculturaland-biological-sciences/citronella.

279. Science Direct. (2021). Estragole. Retrieved from: https://www.sciencedirect.com/topics/agriculturaland-biological-sciences/estragole. 
280. Science Direct. (2021). Eucalyptol. Retrieved from: https://www.sciencedirect.com/topics/agriculturaland-biological-sciences/eucalyptol.

281. Science Direct. (2021). Ferulic Acid. Retrieved from: https://www.sciencedirect.com/topics/biochemistry-genetics-and-molecular-biology/ferulic-acid.

282. Science Direct. (2021). Germacrene. Retrieved from: https://www.sciencedirect.com/topics/medicineand-dentistry/beta-elemene.

283. Science Direct. (2021). Glycosides. Retrieved from: https://www.sciencedirect.com/topics/agriculturaland-biological-sciences/glycosides.

284. Science Direct. (2021). Limonene. Retrieved from: https://www.sciencedirect.com/topics/pharmacologytoxicology-and-pharmaceutical-science/limonene.

285. Science Direct. (2021). Meliacin. Retrieved from: https://www.sciencedirect.com/topics/agriculturaland-biological-sciences/tetranortriterpenoid.

286. Science Direct. (2021). Methyl Eugenol. Retrieved from: https://www.google.com/search?q=biological+activity+of+methyl+eugenol\&rlz=1C1EJFC_enCA803C A803\&oq=biological+activity+of +methyl+eugenol\&aqs=chrome.69i57j0i22i3019.14308j0j7\&sourceid= chrome\&ie $=$ UTF-8.

287. Science Direct. (2021). Salannin. Retrieved from: https://www.sciencedirect.com/topics/chemistry/salannin.

288. Science Direct. (2021). Saponins. Retrieved from: https://www.sciencedirect.com/topics/pharmacologytoxicology-and-pharmaceutical-science/saponins.

289. Science Direct. (2021). Thymol. Retrieved from: https://www.sciencedirect.com/science/article/abs/pii/S0308814616306392\#: :text=Many\%20different $\% 20$ activities $\% 20$ of\%20thymol,antifungal\%20properties\%20have\%20been\%20shown.

290. Science Direct. (2021). Triterpenes. Retrieved from: https://www.sciencedirect.com/topics/pharmacology-toxicology-and-pharmaceuticalscience/triterpenoid.

291. Science Direct. (2021). Triterpenoids. Retrieved from: https://www.google.com/search?q=biological+activity+of+triterpenoids\&rlz=1C1EJFC_enCA803CA80 3\&sxsrf=ALeKk03V0AoN4KqOuhhu4DUHhgMeE-

ZROA\%3A1619815746467\&ei=Qm2MYLb8G_Ka_QaHo5ygAw\&oq=biological+activity+of+triterpe noids\&gs_lcp=Cgdnd3Mtd216EAMyCAghEBYQHRAeMggIIRAWEB0QHjoHCCMQsAMQJzoHCA AQRxCwAzoECCMQJzoCCAA6BggAEBYQHICEElj1MmCSO2gBcAJ4AIAB7gaIAYYukgELMi03 LjQuMS4xLjKYAQCgAQGqAQdnd3Mtd216yAEJwAEB\&sclient=gwswiz\&ved=0ahUKEwi2pa3x66bwAhVyTd8KHYcRBzQQ4dUDCA4\&uact=5.

292. Science Direct. (2021). Ursolic Acid. Retrieved from: https://www.sciencedirect.com/topics/pharmacology-toxicology-and-pharmaceutical-science/ursolicacid.

293. Science Direct. (2021). Zingiberene. Retrieved from: https://www.sciencedirect.com/topics/medicineand-dentistry/zingiberene.

294. Scientific Report. (2017). $\beta$-Eudesmol, an oxygenized sesquiterpene, stimulates appetite via TRPA1 and the autonomic nervous system. Retrieved from: https://www.nature.com/articles/s41598-017-16150-6.

295. Sembulingam, K.; Sembulingam, P. \& Namasiivayam, A. (1997). Effects of Ocimum sanctum Lin One Noise Induced Changes in Plasma Corticosterone Level. Indian Journal of Clinical Physiology and Pharmacology, 41 (2): 139-143.

296. Semwal, D. K.; Semwal, R. B.; Combrinck, S. \& Viljoen, A. (2016). Myricetin: A Dietary Molecule with Diverse Biological Activities. https://www.ncbi.nlm.nih.gov/pmc/articles/PMC4772053/. 
297. Sen, P. (1993). Therapeutic Potentials of Tulsi: from expensive to facts. Drugs News and Views. 1 (2): 15-21.

298. Sen, P.; Maiti P. C.; Puri, S.; Ray A.; Audulov, N. A. \& Valdman, A. V. (1992). Mechanism of antistress activity of Ocimum sanctum Linn Eugenol and Tinospora malabarian in experimental animals. Indian J. Exp. Biol. 30 (7). pg. 592-596.

299. Shackleton, C. M.; Timmermans, H. G.; Nongwe, N., Hamer, N. \& Palmer, N. R. (2007). Direct-use values of non-timber forest products from two areas on the Transkei Wild Coast. Agrekon. 46, pg. 113134. Journal of Molecules, 20, 7438-7453

300. Shah, A. K. \& Mahendra, A. (2009). Immunostimulatory activity of aqueous extract of Azadirachta indica flowers on specific and non-specific immune response. Journal of Natural Remedies. 9 (1). pg. $35-42$.

301. Shah, F. M.; Razaq, M.; Ali, A.; Han, P. \& Chen, J. (2017). Comparative role of Neem seed oil extract, moringa leaf extract and imidacloprid in the management of wheat aphids in relation to yield losses in Pakistan. PLoS One. 12 (9).

302. Shapira, S.; Pleban, S.; Kazanov, S.; Tirosh, P. \& Arber, N. (2016). Terpinen-4-ol: A Novel and Promising Therapeutic Agent for Human Gastrointestinal Cancers. Retrieved from: https://journals.plos.org/plosone/article?id=10.1371/journal.pone.0156540\#: :text=Terpinen\%2D4\%2D ol\%20is\%20a,albicans\%5B13\%2C14\%5D.

303. Sharma, P.; Lokeshwar, T.; Bachwani, M. \& etal. (2011). Review on neem (Azadirachta indica): thousand problems one solution. International Research Journal of Pharmacy: pg. 97-102.

304. Sharma, R.; Kaushik, S.; Shyam, H. et al. (2017). Neem Seed Oil induces Apoptosis in MCF-7 and MDA MB-231Human Breast Cancer Cells. Asian Pac. J. Cancer Prev. 18 (8). pg. 2135-2140.

305. Sharma, V. N. \& Sakena. K. P. (1959). Sodium-nimbidinate-in vitro study of its spermicidal action. India J Med Science. Pg. 1335-1345. Pharmacognosy Journal: Review Article, 2019.

306. Shi, C.; Song, K.; Zhang, X.; Sun, Y.; Sui, Y.; Chen, Y.; Jia, Z.; Sun, H.; Sun, Z. \& Xia, X. (2016). Antimicrobial Activity and Possible Mechanism of Action of Citral against Cronobacter sakazakii. Retrieved from: https://www.ncbi.nlm.nih.gov/pmc/articles/PMC4945043/\#: :text=Citral\%20has\%20been\%20reported $\% 20$ to\%20xhibit\%20antimicrobial\%20activity\%20against\%20pathogenic,aureus $\% 20 \% 5 \mathrm{~B} 24 \% 2 \mathrm{C} 25 \%$ 5D.\&text=Several $\% 20$ reports\%20have $\% 20$ determined $\% 20$ the,plant $\% 2$ Dderived $\% 20$ compounds $\% 20 \mathrm{ag}$ ainst $\% 20 \mathrm{C}$.

307. Shigeharu, I.; Toshio, T. \& Hideyo, Y. (2001). Antibacterial Activity of essential oil and their major constituients against respiratory tract pathogens by gaseous contact. Journal of Antimicrobial chemotherapy. 47.pg. 576-573.

308. Shree, P.; Mishra, P.; Selvaraj, C.; Singh, S. K.; Chaube, R.; Garg, N. \& Tripathi, Y. B. (2020). Targeting COVID-19 (SARS-CoV-2) main protease through active phytochemicals of ayurvedic medicinal plants - Withania somnifera (Ashwagandha), Tinospora cordifolia (Giloy) and Ocimum sanctum (Tulsi) - a molecular docking study. Retrieved from: https://www.tandfonline.com/doi/full/10.1080/07391102.2020.1810778.

309. Siddiqui, A. A. \& Ali, M. (1997). Practical Pharmaceutical Chemistry. 1st ed., CBS Publishers and Distributors, New Dheli, pg. 126-131. Journal of Food and Industrial Vol. 3 (1), pg. 1-5, 2017.

310. Siddiqui, A. A. \& Ali, M. (1997). Practical Pharmaceutical Chemistry. 1st ed., CBS Publishers and Distributors, New Dheli, pg. 126-131. Journal of Microbiology and Antimicrobials Vol. 3 (1), pg. 1-7, 2011.

311. Silva, D. R.; Endo, E.; Filho, B. P. D. \& Nakamura, C. V. (2009). Chemical Composition and Antimicrobial Properties of Piper ovatum Vahl. Retrieved from: https://www.researchgate.net/publication/26593916_Chemical_Composition_and_Antimicrobial_Proper ties_of_Piper_ovatum_Vahl. 
312. Silva, L. L.; Heldwein, C. G.; Reetz, L. G. B.; Horner, R.; Malmann, C. A. \& Heinzmann, B. M. (2010). Chemical Composition, Antibacterial Activity, In Vitro and brine-shrimp toxicity of the essential oil from inflorescence of Ocimum gratissimum L. Braz. J. Pharmacogn. 20. pg. 700-705.

313. Singh, A.; Singh A. K.; Narayan, G.; Singh, T. B. \& Shukla, V. K. (2014). Effect of Neem oil and Haridra on non-healing wounds. Ayu. 35. pg. 398-403.

314. Singh, S. \& Majumdar, D. K. (1995). Analgesic activity of Ocimum sanctum and its possible mechanism of action. Int. J. Pharmacog. 33. pg. 188.

315. Singh, S. \& Sastry, M. S. (1997). Antimicrobial Activity of Neem Oil. Indian Journal of Pharmacology. 13, pg. 102-106. Journal of Scientific Research, Vol. 64, 2020.

316. Singh, S.; Gupta, P. \& Gupta, JJ. (2020). Virtual Structural Similarity Elucidates Bioactivity of Fenchone: A Phytochemical Enriched in Fennel Essential Oil. Retrieved from: https://pubmed.ncbi.nlm.nih.gov/30907324/\#: :text=Background\%3A\%20Fenchone\%20is\%20a\%20nat ural,present $\% 20$ in $\% 20$ fennel $\% 20$ essential $\% 20$ oil.\&text=Fenchone $\% 20$ also $\% 20$ demonstrated $\% 20$ to $\% 20$ possess,a\%20very\%20strong\%20antifungal\%20activity.

317. Sinha, K.C.; Riar, S. S., Tiwary, A. K. et al. (1984). Neem Oil as a vaginal contraceptive. Indian J. Med. Res. 79. pg. 131-136.

318. Siswominhardjo, W.; Sunarintyas, S. B.; Nishimura, M. \& Hamada, T. (2007). The difference of antibacterial effect on neem leaves and stick extract. Int. Chin. J. Dent. 7. pg. 27-29.

319. Sitarek, P.; Rijo, P.; Garcia, C.; Skala, E.; Kalemba, D.; Bilas, A. J.; Szemraj, J.; Pytel, D.; Toma, M.; Wysokińska, H. \& Śliwiński, T. (2017). Antibacterial, Anti-Inflammatory, Antioxidant, and Antiproliferative Properties of Essential Oils from Hairy and Normal Roots of Leonurus sibiricus L. and Their Chemical Composition. Retrieved from: https://www.hindawi.com/journals/omcl/2017/7384061/.

320. Soares, M. O.; Alves, R. C.; Pires, C.; Olivera, M. B. \& Vinha, A. F. (2013). Angolan Cymbopogon citratus used for therapeutic benefits: nutritional composition and influence of solvents in phytochemicals contents and antioxidant activity of leaf extract. Food Chem. Toxicol. 60 (2013). pg. 413-418 Scientific African Vol. 6. (2019).

321. Sophia, J.; Kowshik, J. \& Dwivedi, A. (2018). Nimbolide, a neem limonoid inhibits cytoprotective autophagy to active apoptosis via modulation of the PI3K/ Akt/ GSK3 $\beta$ signalling pathways in oral cancer. Cell Death Dis. 9 (11).pg. 1087.

322. Subramanian \& Lakshmana. (1996). Anonymous. The Indian Pharmacopoeia. Government of India. New Dheli. Ministry of Health and family welfare. Journal of Microbiology and Antimicrobials Vol. 3 (1), pg. 1-7, 2011.

323. Tanko, Y.; Magaji, G. M.; Yerima, M.; Magaji, R. A. \& Mohammed, A. (2008). Anti-nociceptive and anti-inflammatory activities of aqueous leaves extract of Ocimum gratissimum (Labiate) in rodents. The African Journal of Traditional, Complementary and Alternative Medicines. 5 (2). pg. 141-146.

324. TGSC Information System. (2021). beta-bisabolene. Retrieved from: http://www.thegoodscentscompany.com/data/rw1054141.html.

325. Thas, J. J. (2008). Siddha Medicine-Background and Principles and the application for skin diseases. Clin. Dermatol.26 (1).pg. 62-78.

326. Thawabteh, A.; Juma, S.; Bader, M.; Karaman, D.; Scrano, L.; Bufo, S. A. \& Karaman, R. (2019). The Biological Activity of Natural Alkaloids against Herbivores, Cancerous Cells and Pathogens. Retrieved from:

https://www.ncbi.nlm.nih.gov/pmc/articles/PMC6891610/\#: :text=Alkaloids\%20are\%20the\%20most\% 20biologically,camptothecin\%20(CPT)\%20and\%20vinblastine.

327. The Ecology Society of America. (1997). "Ecosystem Services: Benefits Supplied to Human Societies by Natural Ecosystems.”. Retrieved from: Issues in Ecology 2. Washington, DC: Ecological Society of America. 
328. The Free Dictionary. (2021). Elemicin. Retrieved from: https://medicaldictionary.thefreedictionary.com/elemicin.

329. The National Product and Drug Discovery. (2018). Medicinal Plant. Retrieved from: https://www.sciencedirect.com/topics/pharmacology-toxicology-and-pharmaceutical-science/medicinalplant.

330. Tiwari, M.; Dwivedi, U. N. \& Kakkar, P. (2010). Suppression of oxidative stress and pro-inflammatory mediators by Cymbopogon citratus D. Stapf. extract in lipopolysaccharides stimulated murine alveolar macrophages. Food and Chemical Toxicology. 48. pg. 2913-2919.

331. Trivedi, A.; Fatima, N.; Husain, I. \& Misra, A. (2019). An Update on the Therapeutic Potential of Neem and its constituent: A Panacea for All Diseases. Department of Biochemistry, Department of Pathology. Era's Lucknow Medical College and Hospital, Sarfarazgani Lucknow, U. P., India-226003. ERA's Journal of Medical Research. Vol. 6, 1.

332. Trivini, K. K.; Singh, A. K.; Kumar, R.; Gupta, V. \& Tripathi, K. (2013). Ocimum sanctum Finn: A Review on Phytopharmacology and Therapeutic Potential of Tulsi. International Journal of Pharmaceutical and Phytopharmacology Research. 3 (2): 148-151.

333. Trulieve. (2021). Everything You Need to Know About a-Phellandrene And Its Benefits. Retrieved from: https://www.trulieve.com/discover/blog/everything-you-need-to-know-about-a-phellandrene-and-itsbenefits.

334. Turkez, H.; Celik, K. \& Togar, B. (2014). Effects of copaene, a tricyclic sesquiterpene, on human lymphocytes cells in vitro. from: https://www.ncbi.nlm.nih.gov/pmc/articles/PMC4082788/\#: :text=Several\%20biological\%20activities \%20are\%20attributed,(Al\%2Dmaskri\%20et\%20al.\&text=Copaene\%20(COP)\%20is\%20a\%20tricyclic,g revei\%20leaves\%20(Afoulous\%20et\%20al.

335. Udem, G.; Dahiru, D. \& Etteh, C. (2018). In vitro Antioxidant Aqueous and Ethanol Extracts of Mangifera indica Leaf, Stem-bark and Root-bark. Pharmacognosy Communications. 8 (3). pg. 119-124.

336. Upadhyay, S.; Dhawan, S.; Garg, S. \& Talwar, G. B. (1992). Immunomodulatory effects of neem (Azadirachta indica) oil. Int. J. Immunopharmacol. 14. pg. 1187-1193.

337. Vafaie, E. (2019). Guyana F2F Wrap-up: Trainings and Visits. Retrieved from: https://sixleggedaggie.com/tag/guyana/.

338. Vahid, F.; Jahanshir, A.; Javad, N. \& Asgar, E. (2013). Chemical Composition and Antifungal Activity of essential oil of Cymbopogon citratus (D). Stapf. Against three phytophthora species. Greener. J. Biol. Sci. 3. (2013). pg. 292-298. Scientific African Vol. 6. (2019).

339. Viana, G. S.B.; Vale, T. G.; Pinho, R. S. N. \& Matos, F. J. A. (2000). Antinociceptive effect of the essential oil from Cymbopogon citratus in mice. Journal of Ethnopharmacology. 70. pg. 323-327.

340. Vieira, L. (2013). Infection of Aedes aegypti (Diptera: Culicidae) larvae and Adults by the Entomopathogenic Fungus Metarhizium anisopliae (Metschn). Sorokin British Microbiology Research Journal. 3 (3). pg. 309-317.

341. Vishette, S. J.; Patil, M. K.; Deshmukh, A. A. \& Shaikh, J. R. (2019). Phytochemical Analysis of Different Extract of Azadirachta indica Leaves. Journal of Pharmaceutical Sciences, Article No. 27, Pg.: 161-165.

342. Vyas, P. (2011). Use of essential oils against gram negative pathogens. Journal of Drug Delivery and Therapeutics. 2(6). Journal of Pharmacognosy and Phytochemistry; 6(2): 261-264.

343. Wang, J. et al. (2006). "Platensimycin is a selected FabF inhibitor with potent antibiotic properties.". Nature 441, 358-361.

344. Wang, J.; Li, J.; Cao, J. et al. (2010). Antifungal activities of neem (Azadirachta indica) seed kernel extracts on post harvest diseases in fruits. African Journal of Microbiology Research. 4 (11). pg. 1100 1104. 
345. WebMD. (2021). Beta-Sitosterol. Retrieved from: https://www.webmd.com/vitamins/ai/ingredientmono939/beta-sitosterol.

346. Wilson, D. R. (2017). The Potential Health Benefits of Rutin. Retrieved from: https://www.healthline.com/health/potential-benefits-of-rutin.

347. Wilson, D. R. (2018). Why Is Ellagic Acid Important? Retrieved from: https://www.healthline.com/health/ellagic-acid.

348. Wilson, D. R. (2019). What You Need to Know About Citronella Essential Oil. Retrieved from: https://www.healthline.com/health/citronella-oil.

349. Work Nik. (2021). Neral. Retrieved from: https://www.wordnik.com/words/neral.

350. World Health Organization (WHO). (2003). WHO Guidelines on Good Agricultural and Collection Practices (GACP) for Medical Plants? Retrieved from: https://www.researchgate.net/publication/337649086_Medicinal_Plants_the_Medical_Food_and_Nutriti onal_Biochemistry_and_Uses/link/5e5805b44585152ce8f491d9/download.

351. World Health Organization (WHO). (2004). Medicinal Plants. Retrieved from: www.WHO.int/entity/mediacentre/news/notes/2004/np3/en.

352. Wu, M.; Ni, L.; Lu, H.; Xu, H.; Zou, S. \& Zou, X. (2020). Terpenoids and Their Biological Activities from Cinnamomum: A Review. from: https://www.hindawi.com/journals/jchem/2020/5097542/.

353. Xie, Q.; Li, F.; Fang, L.; Liu, W. \& Gu, C. (2020). The Antitumor Efficacy of $\beta$-Elemene by Changing Tumor Inflammatory Environment and Tumor Microenvironment. Retrieved from: https://www.hindawi.com/journals/bmri/2020/6892961/.

354. Lim, X. Y.; The, B. P. \& Tan, T. Y. C. (2021). Medicinal Plants in COVID-19: Potential and Limitations. Retrieved from: https://www.frontiersin.org/articles/10.3389/fphar.2021.611408/full.

355. Xiong, C.; Li, Q.; Li, S.; Chen, C.; Chen, Z. \& Huang, W. (2017). In vitro Antimicrobial Activities and Mechanism of 1-Octen-3-ol against Food-related Bacteria and Pathogenic Fungi. Retrieved from: https://pubmed.ncbi.nlm.nih.gov/28794307/\#: :text=1\%2DOcten\%2D3\%2Dol\%2C\%20known\%20as\% 20mushroom $\% 20$ alcohol,extracted $\% 20$ from $\% 20$ fungi $\% 20$ and $\% 20$ plants.\&text=The $\% 20$ results $\% 20$ sho wed $\% 20$ that $\% 201$,fungal $\% 20$ growth $\% 20$ and $\% 20$ spore $\% 20$ germination.

356. Yagi, S.; Babiker, K.; Tzanova, T. \& Schohn, H. (2016). Chemical composition, antiproliferative, antioxidant and antibacterial activities of essential oils from aromatic plants growing in Sudan. Retrieved from: https://www.sciencedirect.com/science/article/pii/S1995764516301262.

357. Yamni, H. A; Pang, E. C.; Mantri, N. \& Deighton, M. A. (2016). Antimicrobial Activity of Tulsi (Ocimum tenuiflorum) Essential Oil and Their Major Constituents Against Three Species of Bacteria. Frontiers in Microbiology. Vol. 7. Pg. 5.

358. Yanomami, M. I.; Yanomami, I.; Albert, B.; Milliken, W.; Coelho, V. (2014). Hwerimamotimathepe a oni. Manual dos remediostradicionaisYanomami [Manual of Traditional Yanomami Medicine]. Sao Paulo: Hutukara/InstitutoSocioambiental. Retrieved from: https://www.researchgate.net/publication/337649086_Medicinal_Plants_the_Medical_Food_and_Nutriti onal_Biochemistry_and_Uses/link/5e5805b44585152ce8f491d9/download.

359. Zaibeti, W.; Laoueri, H.; Amira, S.; Flamini, G.; Ramdani, I. \& Akkal, S. (2015). CHEMICAL COMPOSITION AND BIOLOGICAL ACTIVITIES OF DAUCUS AUREUS ESSENTIAL OILS FROM EASTERN ALGERIA. Retrieved from: https://scielo.conicyt.cl/scielo.php?script=sci_arttext\&pid=S0717-97072015000400017.

360. Zero Waste Market Place. (2021). Handmade wooden comb - made from neem wood. [Image]. Retrieved from: https://www.zerowastemarketplace.ie/products/handmade-wooden-comb-made-from-neem-wood. 